\title{
Nanoparticle emissions from 11 non-vehicle exhaust sources - A review
}

\author{
Prashant Kumar $^{\text {a, b, }}{ }_{1}$, Liisa Pirjola ${ }^{\text {c, d }}$, Matthias Ketzel ${ }^{\mathrm{e}}$, Roy M. Harrison ${ }^{\mathrm{f}, \mathrm{g}}$
}

${ }^{\mathrm{a}}$ Department of Civil and Environmental Engineering, Faculty of Engineering and Physical Sciences (FEPS), University of Surrey, Guildford GU2 7XH, United Kingdom

${ }^{\mathrm{b}}$ Environmental Flow (EnFlo) Research Centre, FEPS, University of Surrey, Guildford GU2 7XH, United Kingdom

${ }^{\mathrm{c}}$ Department of Physics, University of Helsinki, FI-00064 Helsinki, Finland

${ }^{\mathrm{d}}$ Department of Technology, Metropolia University of Applied Sciences, FI-00180 Helsinki, Finland

${ }^{\mathrm{e}}$ Department of Environmental Science, Aarhus University, DK-4000 Roskilde, Denmark

${ }^{\mathrm{f}}$ Division of Environmental Health and Risk Management, School of Geography, Earth and Environmental Sciences, University of Birmingham, Edgbaston, Birmingham B15 2TT, United Kingdom

${ }^{\mathrm{g}}$ Department of Environmental Sciences / Center of Excellence in Environmental Studies, King Abdulaziz University, PO Box 80203, Jeddah, 21589, Saudi Arabia

\section{Abstract}

Nanoparticle emissions from road vehicles have been studied extensively in the recent past due to their dominant contribution towards the total airborne particle number concentrations (PNCs) found in the urban atmospheric environment. In view of upcoming tighter vehicle emission standards and adoption of cleaner fuels in many parts of the world, the contribution to urban nanoparticles from non-vehicle exhaust sources (NES) may become more pronounced in future. As of now, only limited information exists on nanoparticle emissions from NES through the discretely published studies. This article presents critically synthesised information in a consolidated manner on 11 NES (i.e. roadtyre interaction, construction and demolition, aircraft, ships, municipal waste incineration, power plants, domestic biomass burning, forest fires, cigarette smoking, cooking, and secondary formation). Source characteristics and formation mechanisms of nanoparticles emitted from each NES are firstly discussed, followed by their emission strengths, airborne concentrations and physicochemical characteristics. Direct comparisons of the strengths of NES are not straightforward but an attempt has been made to discuss their importance relative to the most prominent source (i.e. road vehicles) of urban nanoparticles. Some interesting comparisons emerged such as $1 \mathrm{~kg}$ of fast and slow wood burning produces nearly the same number of particles as for each $\mathrm{km}$ driven by a heavy duty vehicle (HDV) and a light duty vehicle, respectively. About 1 minutes of cooking on gas can produce the similar particle numbers generated by $\sim 10$ minutes of cigarette smoking or $1 \mathrm{~m}$ travel by a HDV. Apportioning the contribution of numerous sources from the bulk measured airborne PNCs is essential for determining their relative importance. Receptor modelling methods for estimation of source emission contributions are discussed. A further section evaluates the likely exposure risks, health and regulatory implications associated with each NES. It is concluded that much research is needed to provide adequate quantification of all nanoparticle sources, and to establish the relative toxicity of nanosize particles from each.

Key words: Particle number concentrations; Non-exhaust emissions; Number size distributions; Exposure risks and regulation; Outdoor ultrafine particle formation

\footnotetext{
1Corresponding author: Civil Engineering (C5), Tel. +44 1483 682762; fax: +44 1483 682135; Email addresses: P.Kumar@ surrey.ac.uk, Prashant.Kumar@cantab.net
} 


\section{Research highlights}

- Nanoparticle emissions from 11 non-vehicle exhaust sources (NES) are reviewed

- Limited information exists but encouraging progress made to characterise NES

- No air quality regulations exist currently to control nanoparticle exposure

- Physicochemical characterisation and exposure to NES derived nanoparticles needed

- Relative toxicity and contribution of NES produced nanoparticles unknown

\section{Introduction}

Atmospheric nanoparticles (referring here to those below $300 \mathrm{~nm}$ in diameter to represent most of the particle number concentration, PNC) are of large concern to both the air quality management and science communities due to their links with adverse impacts on public health. Diesel engine exhaust, containing a type of nanoparticle that large populations are exposed to in everyday life, has recently been classified as carcinogenic to humans (Group 1). This classification came from the International Agency for Research on Cancer (IARC), which is part of the World Health Organization (WHO), based on sufficient evidence that exposure is associated with an increased risk for lung cancer (IARC, 2012). Before, it was classified as probably carcinogenic to humans (Group 2A). This kind of health concern has led to a strong imperative to gain better understanding of the sources so that effective control measures can be envisaged. In what follows, the terms 'nanoparticle' and 'PNCs' are used interchangeably according to the context, so is the case with the words 'ambient' and 'atmospheric'. The term 'ultrafine' is specifically used when referring to particles below $100 \mathrm{~nm}$ in diameter. It is worth mentioning that nanoparticles originate by natural (atmospheric formation), incidental (side product of anthropogenic activities) and engineered processes (deliberately produced with specific properties, having at least one dimension in the $1-100 \mathrm{~nm}$ range). The focus of this article is on the previous two types and these should not be confused with the latter type (i.e. engineered nanoparticles).

Numerous studies based on the mass metric show that vehicular sources can comprise up to $80 \%$ of total $\mathrm{PM}_{10}$ and/or $\mathrm{PM}_{2.5}$ in urban areas (AQEG, 1999; Baldauf et al., 2008; Chan et al., 1999; Fraser et al., 2003; Harrison et al., 1999; Schauer et al., 1996a; Wåhlin et al., 2001). The case of nanoparticles is similar when considering measurements close to the sources. For instance, the contribution from road vehicles can be up to $90 \%$ of total PNCs in polluted urban environments (Harrison et al., 2011; Johansson et al., 2007; Kumar et al., 2010c, 2011b; Pey et al., 2009), though this contribution varies significantly when measured in atmospheric environments not dominated by road vehicle emissions. Irrespective of the measurement locations and meteorological conditions, it is generally found that the particles below $100 \mathrm{~nm}$ and below $300 \mathrm{~nm}$ contribute over $80 \%$ and $99 \%$ of total PNCs, respectively (Heal et al., 2012).

Current knowledge of which components of particulate matter by source, composition and size have the greatest impact on public health is weak and inconclusive despite significant progress being made in the past (Pope III and Dockery, 2006). The case for nanoparticles is even less addressed and their contribution as well as the physical and chemical characteristics from various non-vehicle exhaust sources (NES) to urban airborne nanoparticles is hardly known. We are referring here the NES to the sources other than the tailpipe exhausts of ground vehicles. A number of NES are the focus of this article (see justification in Section 2), including particles arising from road-tyre 
interaction, brake wear and resuspension (Dahl et al., 2006; Mathissen et al., 2011), industrial emissions such as from power plants ( $\mathrm{Li}$ et al., 2009), idling, taxiing and take-off from aircraft at airports (Hu et al., 2009; Mazaheri et al., 2009), ship emissions from ports or harbours (Saxe and Larsen, 2004), construction, demolition and processing of concrete (Hansen et al., 2008; Kumar et al., 2012c), residential and commercial cooking (Buonanno et al., 2009b; Buonanno et al., 2010), domestic biomass burning (Hosseini et al., 2010), forest fires and burning of agriculture residue (Reid et al., 2005), municipal waste incineration (Buonanno et al., 2009a), cigarette smoking (Wu et al., 2011), and secondary formation (Morawska et al., 2010).

Thus far, whatever is known about the nanoparticle emissions from the NES is either through the discretely published independent studies or via the regional or national emission inventories. While the former method offers site specific localised information, the latter provides generalised results for a region. A handful of emission inventories currently exist for nanoparticle emissions from the NES. For Europe, a first size-resolved anthropogenic particle number emission inventory was compiled for the reference year 2005 within the framework of European Integrated Project on Aerosol Cloud Climate and Air Quality Interactions (EUCAARI) project (Kulmala et al., 2011). The emission data base includes particles in the 10-300 $\mathrm{nm}$ size range and distributes the particle number emissions in 15 different size bins. Likewise, some models such as Global Model for Aerosol Processes (GLOMAP) contains sizeresolved emission data in 20 bins that span in the 3-10,000 nm range (Reddington et al., 2011). Another such emission inventory was carried out for the UK for 2008 (AEA, 2010). However, the study approximated the mass concentrations of nanoparticles (but not the number concentrations) based on fraction of $\mathrm{PM}_{10}$ and computed the following contributions: combustion in energy and transformation industry $(8 \%)$, combustion in manufacturing industry $(7 \%)$, industrial off-road mobile machinery $(9 \%)$, other (non-road) transport (14\%), production processes (15\%), agriculture (9\%), waste (4\%). Unfortunately this does not map well onto the NES sources considered in this review, and looks very different to a similar inventory published for 2001 (AQEG, 2005).

\section{Scope, aims and article outline}

The scope of the article is limited to nanoparticles and hence the focus remains on number concentrations of particles. We refer to coarse $\left(\mathrm{PM}_{2.5-10}\right)$ and fine $\left(\mathrm{PM}_{2.5}\right)$ airborne particles only where necessary to set out the context for nanoparticles. A total of 11 major NES are comprehensively evaluated. It should be noted that the road vehicles are intentionally left out of the scope of this article since a number of well documented review articles covering their origin, characterisation, measurement methods, instrumentation, dispersion modelling and their impacts on health, visibility impairment and climate change already exist; see summary of these articles in Kumar et al. (2012a) and references therein.

All the sources chosen for study contribute nanoparticles directly to the outdoor atmospheric environment, other than cigarette smoking and cooking both of which make a direct and indirect contribution. For instance, cigarette smoke is not strictly an indoor source as increasingly smoking takes place out of doors and hence this both a direct (i.e. outdoor) and indirect (through escaping from indoors) source to the outdoor environment (Section 4.9.1). Likewise emissions from cooking activities in 
both residential and commercial settings reach the outdoor ambient environments through natural or mechanical ventilation (Section 4.10.1). Secondary formation is not a primary source, like others, but has been considered due to its significant contributions in rural and background areas besides leading to nucleation burst in urban areas. It should be noted that emission sources which emit predominantly to the indoor environment, including vacuum cleaners (Knibbs et al., 2012), office printers (McGarry et al., 2011), ironing, candles, hair dryers or steam irons (Wallace and Ott, 2011), as well as exposure to emissions during various day to day indoor and outdoor activities (Buonanno et al., 2012a), or exposure in transport microenvironments (Knibbs et al., 2011) are beyond the scope of this article, mainly for reasons of brevity.

The aims of this study are to critically synthesise the latest information on NES derived nanoparticles, analysing their source strengths, relative importance and contributions, receptor modelling methods of source emission contributions, and the regulatory approaches to limit their probable impacts on human health. In addition, the research gaps and future priorities to fill the underlying research openings are highlighted. It is worth noting that the aim of this work is not to construct any emission inventory but to further elucidate the main NES for nanoparticles under varying environmental conditions. In our view, this is the first article which comprehensively evaluates a number of technical aspects related to the nanoparticle emissions from various NES and presents a critically synthesised summary in one place.

The article starts with a general overview of NES (Section 1), followed by defining the scope of work (Section 2) and their importance for assessment (Section 3). The major thrust of the article is on evaluating the source characteristics, formation mechanisms, emissions and physicochemical characteristics of nanoparticles produced by a total of 11 NES (Section 4). Further sections present a critical synthesis on their relative contributions (Section 5), some methods of source estimation (Section 6), likely exposure to the population in close vicinity and far from such sources, health and regulatory concerns (Section 7), and summary and further work (Section 8).

\section{Importance of nanoparticle emissions from the NES}

The importance of individual sources in terms of their contribution and possible exposure to nanoparticles may become apparent in future as the vehicle exhaust emissions decline due to the use of renewable fuels (Kumar et al., 2010b) and low sulphur fuels (Jones et al., 2012; Wåhlin, 2009), together with the significant improvements in engine technology and exhaust after-treatment triggered by the stringent exhaust emission standards (EU, 2008). Inclusion of particle number based vehicle emission standards in Euro 5/6 and fitting or retrofitting of diesel particulate filters (DPF) in coming years are a few such examples of measures for reducing nanoparticle emissions. The former is already implemented in Europe and the latter, for example, has recently been implemented in the London Low Emission Zone from January 2012 for diesel vehicles not complying with the Euro IV emission standard.

Contributions from individual NES may be more localised, site specific and relatively small in a few cases compared with vehicular emissions, but their combined contribution could be large and comparable especially in the close vicinity of such 
sources. Moreover, physical and chemical properties for nanoparticles from NES could differ from those originated by road vehicles due to their unique formation mechanism (see Section 4). Hence, these could show different health effects which are though yet to be established (see Section 7). Given the limited published information on many NES, quantifying the contribution and understanding their physicochemical characteristics and dynamics is vital for the regulatory authorities and policy makers for designing the mitigation strategies and to compute their individual contributions and impacts on public health and local air quality.

\section{Source characteristics, formation mechanisms, emissions and physicochemical characteristics of NES derived nanoparticles}

This section focuses on the nanoparticle emissions from the 11 NES one by one. A sample summary of relevant studies is provided in Table 1. Each source has distinct characteristics and is hence worthy of detailed discussion. A few of them are covered in great detail and the rest are summarised concisely in the interests of brevity. Covering of these many sources also necessitates the citation of a very large body of relevant published specialist, research and review articles.

\subsection{Road-tyre interaction, brake wear and re-suspension 4.1.1 Source characteristics and nanoparticle formation}

Road dust can be defined as a complex mixture of non-exhaust particles that originate from interaction processes of the road pavement and tyre (i.e. road and tyre wear), and brake wear, but it also includes re-suspension of deposited road dust. Besides the debris from tyre and brake wear, the re-suspended dust might be originated from other sources; for example, from exhaust, de-icing salt and sand, kerbside, nearby construction works or dirty roads, or it might be delivered with long range transport. Road dust has been recognized as a dominant source of $\mathrm{PM}_{10}$ in urban areas. Particularly, observed high concentrations during spring time in Scandinavia, North America and Japan have been linked to traction control methods, i.e. sanding and the use of studded tyres during winter.

In recent years, several studies have focused on the particulate emissions of nonexhaust particles including laboratory measurements by road simulators (Aatmeeyata et al., 2009; Dahl et al., 2006; Gustafsson et al., 2008; Kupiainen et al., 2005), as well as real-world measurements by mobile units (Fitz et al., 2005; Hussein et al., 2008; Kreider et al., 2010; Kuhns et al., 2001; Kupiainen and Pirjola, 2011; Mathissen et al., 2011; Pirjola et al., 2009; Zhu et al., 2009). Road simulators are helpful to study the contributions from tyre and road wear isolated under laboratory conditions whereas as the mobile units measure additionally the contribution from re-suspended dust present under ambient conditions. Most of these papers concentrate in the $\mathrm{PM}_{10}$ emissions; only a few of them report emissions and characteristics of nanoparticles.

Tyre wear particles are formed mechanically by tyre abrasion at the road surface and are assumed to be primarily coarse particles (Kupiainen et al., 2005; Tervahattu et al., 2006; Thorpe and Harrison, 2008). However, laboratory experiments by Dahl et al. (2006) and Gustafsson et al. (2008) indicate that tyre wear may also contribute significantly to nanoparticle emissions by gas-to-particle conversion processes, i.e. organic tyre material can evaporate and subsequently re-condense onto small particles. 
Road wear particles are formed due to frictional processes between the pavement aggregate particles and the tyre tread. In urban areas two types of street pavements, asphalt and concrete, are used. Asphalt is comprised primarily of mineral aggregates (95\%), the reminder is mostly filler and bituminous binder (Thorpe and Harrison, 2008). The composition of asphalt pavements, particularly stone material and its grain size, has impact on the wear resistance of the asphalt and particle emissions. Concrete pavements have coarse aggregates bound together into a firm construction with cement and sand (Luhana et al., 2004). Identification of a suitable tracer species for road surface wear has proven to be very difficult (Thorpe and Harrison, 2008). Dahl et al. (2006) studied particle number production at the road-tyre interface in a road simulator for studded and non-studded winter tyres. They observed a significant amount of particles $<200 \mathrm{~nm}$, which probably originated from the tyres, unlike the particles $>320 \mathrm{~nm}$ which conceivably consisted of carbon reinforcement filler and mechanically generated mineral grains from the stone material in the pavement.

Frictional contact between brake system components generates particles across a wide range of diameters from a few hundred nanometers to a few tens of micrometers (for a review, see Thorpe and Harrison, 2008). Most of the studies have reported high $\mathrm{PM}_{10}$ and $\mathrm{PM}_{2.5}$ concentrations (Garg et al., 2000; Iijama et al., 2007; Sanders et al., 2003; Wåhlin et al., 2006); however, a significant portion of ultrafine particles has also been observed. For instance, Garg et al. (2000) measured a large number of particles smaller than $30 \mathrm{~nm}$ in some wear tests on a brake dynamometer. Because the brake wear process produces very high temperature at the brake/rotor interface iron might melt and many of the brake lining materials (fibres, abrasives, lubricants, fillers, binders) might decompose. Likewise, some of the brake pad materials volatilise during braking and condense in the airstream, contributing to the small particle fraction (Sanders et al., 2003).

\subsubsection{Nanoparticle emissions and their characteristics}

Dahl et al. (2006) studied ultrafine particle emissions produced by the road/tire interface on a laboratory road simulator. They reported particle emission factors in the range $4 \times 10^{11}-3 \times 10^{12} \mathrm{~km}^{-1}$ at speeds of $50 \mathrm{~km} \mathrm{~h}^{-1}$ and $70 \mathrm{~km} \mathrm{~h}^{-1}$ for studded and non-studded tires, respectively. Likewise, Gustafsson et al. (2008) estimated PNCs in the $15-700 \mathrm{~nm}$ size range from the road-tyre interaction on a road simulator between $1.81-2.65,0.72-0.82$, and $0.14-0.17\left(\times 10^{4}\right) \mathrm{cm}^{-3}$ for different road surfaces at a vehicle speed of 70,50 and $30 \mathrm{~km} \mathrm{~h}^{-1}$, respectively. The PNC from the $30 \mathrm{~km} \mathrm{~h}^{-1}$ test was in the same range as the background level $\left(0.12-0.17 \times 10^{4} \mathrm{~cm}^{-3}\right)$. Particle number emissions increased strongly with increasing speed for all combinations of tyres and pavements.

A recent study by Mathissen et al. (2011) investigated generation of ultrafine particles from the tyre road interface during real driving. Based on the results, an upper limit of the emission factor of $1 \times 10^{11} \# \mathrm{~km}^{-1}$ for steady straight driving was derived for a summer tyre. No ultrafine particle formation was found for normal braking conditions. Nevertheless, full stop braking activated the anti-lock brake system which resulted in high number of nanoparticles. The authors suggested that these particles originated from the tyres and not from the road. Particle number size distribution depended on the initial vehicle speed; a nucleation mode (brake wear particles) peaking at $10 \mathrm{~nm}$ and a second mode between $30-60 \mathrm{~nm}$ was observed with $100 \mathrm{~km} \mathrm{~h}^{-}$ ${ }^{1}$, whereas a unimodal size distribution peaking at 70-90 nm was observed at $30 \mathrm{~km} \mathrm{~h}^{-}$ 
${ }^{1}$. An exponential increase of the particle concentration with velocity was measured directly at the disc brakes for full stop braking.

Aatmeeyaa et al. (2009) simulated road tyre interaction on a cylindrical concrete road simulator in a laboratory. The number size distributions showed bimodal structure with peaks at $330 \mathrm{~nm}$ and $1.7 \mu \mathrm{m}$. Unfortunately, particles smaller than $300 \mathrm{~nm}$ could not be captured by their analyser. Almost $50 \%$ of the particle mass of $\mathrm{PM}_{10}$ was present below $1 \mu \mathrm{m}$. For a summer tyre they found an increasing linear trend in particle mass emissions with an increasing load on a tyre.

Dahl et al. (2006) took TEM images of $40 \mathrm{~nm}$ particles from road tyre wear to study the morphology of the particles. They suggested that the observed agglomerates of almost spherical particles originate from the carbon black reinforcing fillers or from small inclusions of excess $\mathrm{ZnO}$ and $\mathrm{ZnS}$ which are used in the rubber vulcanization process. Liquid materials observed in the particles might be the oils used as softening fillers. The elemental analysis showed that the relative elemental composition was quite stable over the particle size range of 0.11-10 $\mu \mathrm{m}$ and different combinations of tyre and pavement, besides that sulphur and zinc were enriched in the small submicron particle sizes indicating that tyre wear is a likely source of the ultrafine particles. However, most of the mass emitted originated from the pavement, and only a relatively small mass contribution was from the tyres (Gustafsson et al., 2008).

\subsection{Construction and demolition}

\subsubsection{Source characteristics and nanoparticle formation}

Evidence suggests the release of fine and coarse particles from the building activities (e.g. construction, demolition, and refurbishment) can increase the peak concentrations to several times above the background. For example, the short term peak concentrations of $\mathrm{PM}_{10}$ were reported over 1000 times higher compared with the pre-implosion levels during the demolition of a 22-storey residential building in Baltimore (Beck et al., 2003). The 24-h daily mean $\mathrm{PM}_{10}$ concentrations were also reported to increase over the $50 \mu \mathrm{g} \mathrm{m}^{-3}$ EU limit values as a consequence of a range of building works in London (Fuller and Green, 2004) and Cardiff (Deacon et al., 1997). Likewise, demolition of high rise buildings in Chicago (Illinois, USA) showed between 4 and 9 times increase of $6-\mathrm{h}$ averaged $\mathrm{PM}_{10}$ concentrations against the background at $42 \mathrm{~m}$ downwind of demolition site (Dorevitch et al., 2006). While numerous studies are available on the dust emissions from activities such as arc welding (Lee et al., 2007), drilling (Shan et al., 2012), cutting (Khettabi et al., 2010), unintentional release of airborne nanoparticles from major building activities such as construction, demolition, recycling and refurbishment is largely unknown. As discussed in subsequent sections, only a handful of studies have looked into this topic but none of them offer much information on the number and size distributions released from different building activities, their emission strength or physicochemical characteristics, or possible exposure and health impacts.

Nanoparticles can escape to the ambient environment during the use of crushers, screeners, cutting and drilling activities at construction plants due to the mechanical attrition between the building materials. The diesel fuel combustion in construction machinery is another source of nanoparticles at construction and demolition sites, besides the soil excavation. The soil at any construction site is likely to be disturbed due to the earthworks activities such as excavation, soil-stripping, and ground 
levelling. Together with the fine particles, heavy metals and pesticides that had very long residence time have a strong tendency to get picked up by the wind from the soil and dispersed into the surrounding environment. Furthermore, recent trends to incorporate carbon nanotubes and plasticizers (e.g. nano-silica, $\mathrm{Fe}_{2} \mathrm{O}_{3}, \mathrm{SiO}_{2}$ and $\mathrm{TiO}_{2}$ ) within concrete mixes to improve workability and strength introduce an additional potential source of nanoparticles within the concrete structures (Nazari and Riahi, 2011). This nanomodified concrete, when fractured, can also release potentially hazardous particles in the nanosize range. Recycling of materials at concrete recycling plants, and refurbishment and demolition activities are further potential sources. The quantity of particles released during demolition could vary depending on the type of demolition method deployed. These methods could include mechanical demolition using heavy equipment, wrecking ball, pneumatic jack and excavators, or the implosion method (Dorevitch et al., 2006). The former take longer demolition time for a structure than the latter, and consequently can result in prolonged exposure. Conversely, the implosion method is near-instantaneous but can produce several times higher peak concentrations for short-term exposure over the background levels (Beck et al., 2003). While the knowledge in relation to coarse and fine particles is significant (Dorevitch et al., 2006; Kukadia et al., 2003), this is nearly non-existent for nanoparticle emissions (see Section 4.2.2).

\subsubsection{Nanoparticle emissions and their characteristics}

One of the rare studies on nanoparticle emission measurements was conducted by Hansen et al. (2008), though their main objectives were to look at the fungal airborne spores during the demolition of a hospital building. They measured the particles at $1.50 \mathrm{~m}$ height above the ground level within 22 and $31 \mathrm{~m}$ distances from the four-storey concrete hospital building in Essen (Germany) that was demolished. The PNCs below $100 \mathrm{~nm}$ size were found to be increased to about 1.6 times during demolition compared with the background PNCs. A recent study by Kumar et al. (2012c) investigated the release of particle number and size distributions in the 5-560 $\mathrm{nm}$ range from the three simulated building activities: the crushing of concrete cubes, the demolition of old concrete slabs, and the recycling of concrete debris. The measurements were taken in a controlled laboratory environment, at about $0.15 \mathrm{~m}$ away from the samples since the aim was to investigate the emission rates of nanoparticles. The measured PNCs were adjusted after subtracting the background PNCs. The net PNCs during cube crushing, slab demolition, and 'dry' and 'wet' recycling events were measured as $\sim 0.77,19.1,22.7$ and $1.8\left(\times 10^{4}\right) \mathrm{cm}^{-3}$, respectively. These preliminary results confirmed the release of nanoparticles, showing the majority of new PNC release below $100 \mathrm{~nm}$ as opposed to the bulk of new particle mass concentrations (PMC) emissions that were above $100 \mathrm{~nm}$. The measured PNCs can, however, change appreciably depending on the factors such as the distance of the sampling location from the source due to transformation of particles (Kumar et al., 2011a). Meteorology, demolition methods and structure type may further affect the measured PNCs in operational conditions. Nanoparticles emitted from building activities are likely to be non-volatile and hence can have a longer atmospheric lifetime (Kumar et al., 2010a) compared with those originated from traffic with a notable volatile fraction (Dall'Osto et al., 2011). This can increase the chances of their escape to surrounding environments and the exposure of the workers and the local community.

\subsection{Ship emissions}




\subsubsection{Source characteristics and nanoparticle formation}

More than $80 \%$ of world trade is transported by ships, making the marine traffic a significant and growing source of diesel emissions to the local and global environments that affect global climate, air quality and human health (Fuglesvedt et al., 2009). Ocean-going ships represent approximately 9\% of global SOx emissions and $18-30 \%$ of the world's NOx pollution. They also produce as much primary PM mass as road traffic $\left(\sim 1.7 \mathrm{Tg} \mathrm{yr}^{-1}\right)$, including $\sim 2 \%$ of global black carbon (BC) from all sources, and $7.5 \%$ of fossil and biofuel sourced organic matter (OM) emissions (Corbett et al., 2010; Eyring et al., 2005; Lack et al., 2009). Most of the studies focus on NOx, SOx, and PM emissions. Recent publications have started to be concerned with nanoparticle emissions and their measurement.

Large ships are primarily powered by diesel propulsion systems that can either use residual fuels or distillates. Residual fuel refers to a broad category of low-grade fuel with longer carbon chain length, high density, high viscosity and high concentration of impurities such as sulphur, ash, asphaltenes, and metals (Sinha et al., 2003). Heavy fuel oil (HFO), pure or nearly pure residual oil, represents over $80 \%$ of the fuel consumed by the world ship fleet (Murphy et al., 2009). Distillates are refined fuels of various grades that are more expensive than residual fuels but by combustion result in smaller pollutant concentrations. Due to their higher costs, distillates are generally used only by the auxiliary engines for port activities for generating electricity for light, heating, ventilation, air-conditioning, cold storage, cooking, etc. (Saxe and Larsen, 2004), and by the main engines for manoeuvring in the harbour area (arriving or leaving the port including turning, braking and accelerating).

Shipping emits both primary and secondary particles. Incomplete combustion of carbon produces primary soot particles. Due to impurities in HFO, these particles also include vanadium and nickel. Emissions of $\mathrm{SO}_{2}$ are determined by the fuel sulphur content; residual fuels produce higher $\mathrm{SO}_{2}$ emissions than distillate fuels. Sulphur is oxidized to $\mathrm{SO}_{2}$ and further to $\mathrm{SO}_{3}$ during combustion. The amount of $\mathrm{SO}_{3}$ depends on the combustion temperature, but the reaction is catalyzed by the presence of vanadium (Isakson et al., 2001). During dilution and cooling $\mathrm{SO}_{3}$ reacts with water vapour forming sulphuric acid which subsequently can nucleate forming secondary particles and/or condense onto pre-existing particles.

Nanoparticle emissions depend on the technology deployed, i.e. engine type (main and auxiliary, age and power), fuel type and consumption, after-treatment system (e.g. selective catalytic reduction, SCR), as well as ship's type and operating conditions (engine load, speed and acceleration, shipping routes) and weather conditions. SCR is able to reduce NOx emission by $90-99 \%, \mathrm{HC}$ and $\mathrm{CO}$ by $80-90 \%$, and soot by $30-$ $40 \%$ for full load (Eyring et al., 2005). Fridell et al. (2008) found that the particle mass emissions reduced to about half, over the whole size range, by using a SCR system. Different scrubbing systems have been commonly applied to diesel power plants on land, but until now their commercial installation on ships have been scarce (Jalkanen et al., 2011). HFO fuel emits more pollutants than distillate fuels.

\subsubsection{Nanoparticle emissions and their characteristics}

Particulate matter, mostly mass concentration but recently also number size distribution, in marine engine exhaust has been studied in laboratory conditions on engine test beds (Kasper et al., 2007; Lyyränen et al., 1999; Petzold et al., 2008), on- 
board from the ship pipe (Agrawal et al., 2008b; Fridell et al., 2008; Moldanova et al., 2009; Murphy et al., 2009), in ship plumes by aircraft (Murphy et al., 2009; Petzold et al., 2008; Sinha et al., 2003) or by ships (Lack et al., 2009), as well as by performing stationary measurements in the port areas (Ault et al., 2009; Healy et al., 2009; Isakson et al., 2001; Jonsson et al., 2011).

In fresh exhaust studied by test bed, at near 100\% engine load, Lyyränen et al. (1999) found that the mass size distributions from medium-speed diesel engines are bimodal with a main mode at $60-90 \mathrm{~nm}$ and a second mode at $7-10 \mu \mathrm{m}$ in aerodynamic diameter. Particle morphology analysis showed that the smallest particles in 40-90 $\mathrm{nm}$ sizes are almost spherical and are generated by nucleation of ash components (V, $\mathrm{Na}, \mathrm{Ca}, \mathrm{Ni}, \mathrm{Al}$, silicon) evaporating during combustion (Lyyränen et al., 1999). These particles further grow by condensation and agglomeration. The larger mode particles are mainly agglomerates of different sizes consisting of the small particles. Microstructure and elemental analysis of ship combustion particles by Moldanova et al. (2009) showed three distinct morphological structures with quite different chemical composition: (i) soot aggregates with significant content of $\mathrm{V}, \mathrm{Ni}$ and $\mathrm{S}$ dominate the sub-micrometer fraction of the mass size distribution, (ii) mineral and ash is found in particles $>200 \mathrm{~nm}$, and (iii) spherically shaped carbonaceous char particles in the micrometer size. Furthermore, organic carbon particles with a size of $100 \mathrm{~nm}$ originating from unburned fuel and/or lubricant oil were observed.

The number size distribution peaked at 40-60 nm (Lyyränen et al., 1999). Somewhat smaller particles peaking at $20-40 \mathrm{~nm}$ and forming a unimodal number size distribution were observed by Kasper et al. (2007) who studied a low-speed marine diesel engine. A four-stroke marine diesel engine showed a bimodal number size distribution peaking at $15 \mathrm{~nm}$ and $50 \mathrm{~nm}$ for engine loads $>75 \%$ but changed to unimodal peaking at $50 \mathrm{~nm}$ for loads $<75 \%$ (Petzold et al., 2008). They concluded that the smallest particles $(<30 \mathrm{~nm})$ were composed predominantly of sulphuric acid water clusters while the large combustion particle mode contains most of the nonvolatile black carbon (BC), organic carbon (OC) and ash. Around $60-70 \%$ of the PNC was evaporated by applying a thermodenuder (Jonsson et al., 2011; Petzold et al., 2008). Kasper et al. (2007) report even a 86\% decrease in total PNCs with a thermodenuder but their SMPS could not record particles smaller than $10 \mathrm{~nm}$.

Performing in-stack measurements on-board, Murphy et al. (2009) also observed a bimodal structure for particle number size distribution; one mode ranging from 5 to 8 $\mathrm{nm}$ and the other from 30 to $100 \mathrm{~nm}$. Sulphur and vanadium had distinctive peaks from both populations of particles. The mass ratio of organic carbon to sulphate was 0.23 and was constant with the particle size.

Measurements of airborne particles showed that the PNCs above the $10 \mathrm{~nm}$ size range near the ship was $7.8 \times 10^{5} \mathrm{~cm}^{-3}$; the majority of the particle size distributions (more than $90 \%$ of PNCs) was found below a diameter of $100 \mathrm{~nm}$ (Murphy et al., 2009). The mass spectrometer (C-ToF-AMS) showed that the airborne particles comprised around $31 \%$ of dry mass based organics at $100 \mathrm{~m}$ distance from the stack; this ratio was almost constant when the ship plume aged and diluted into the marine boundary layer (up to $60 \mathrm{~min}$ ). The non-organic mass appeared to be almost entirely sulphuric acid $(68-70 \%)$. The mass ratio of $\mathrm{OC}: \mathrm{SO}_{4}$ was increased to 0.3 during the first $100 \mathrm{~m}$ from the stack in the particle size range of smaller than $100 \mathrm{~nm}$. This indicated that 
organic condensation occurred very fast after the stack. Recently, Robinson et al (2007) found that most primary organic-particulate emissions are semivolatile and partially evaporate with rapid atmospheric dilution, creating substantial amount of low-volatility gaseous. Photo-oxidation of these gases rapidly generates secondaryorganic aerosol production exceeding that from the original precursors. Lack et al. (2009) chased ship plumes with a research vessel, and report that the PNC was dominated by nucleation mode particles smaller than $13 \mathrm{~nm}$. They also suggest emission or very fast formation of small sulphuric acid particles that subsequently grow by condensation and coagulation. Furthermore, they found that emissions of $\mathrm{SO}_{4}{ }^{2-}$ and $\mathrm{OM}$ linearly correlate with fuel sulphur content while emissions of $\mathrm{BC}$ are heavily dependent on engine type.

In a port area of Ireland, Healy et al. (2009) measured the maximum PNCs of $2.1 \times 10^{5}$ $\mathrm{cm}^{-3}$ for particles in the $20-100 \mathrm{~nm}$ size range. The mass spectrometer (ATOFMS) showed that single particles in the size range $150-900 \mathrm{~nm}$, peaking at $225 \mathrm{~nm}$, contained internally mixed $\mathrm{OC}, \mathrm{EC}, \mathrm{V}, \mathrm{Ni}, \mathrm{Na}, \mathrm{Ca}$, nitrogen-containing organic carbon and sulphate, in agreement with the observation of the other research groups (Ault et al., 2009; Moldanova et al., 2009; Murphy et al., 2009). A local freshly emitted ship exhaust source was suggested to be the origin of these particles.

\subsection{Aircraft and airports}

\subsubsection{Source characteristics and nanoparticle formation}

The commercial air traffic has been increasing over the last decades. Emissions from aircrafts, among them nanoparticles, have been a major concern for climate change since they are emitted in the free troposphere during cruise and might alter cloud properties and the radiation balance (Boucher, 1999; IPCC., 1999). Moreover, aircraft emissions are causing health effects both globally as on the local scale for individuals working at the airports or flight-support facilities or living in the vicinity of airports (Barrett et al., 2010; Unal et al., 2005).

It is well recognized that emissions from aircraft engines together with the auxiliary power unit (APU) and the ground handling equipment contribute significantly to high air pollution concentrations at the apron where the ground handling staff is operating (Ellermann et al., 2011; Kurniawan and Khardi, 2011). Ground handling equipment uses often similar technology (diesel or gasoline engines) as normal road traffic. Road traffic exhaust is not focus of this paper and the emissions from ground handling equipment are also not discussed in detail here. Their contribution to the measured ambient concentrations at airports is however taken into account.

Aircraft related pollutants such as $\mathrm{PM}, \mathrm{BC}, \mathrm{CO}, \mathrm{NO}_{\mathrm{x}}$ and $\mathrm{PAH}$ have been in the focus for a longer time (Agrawal et al., 2008a; Herndon et al., 2005; Petzold et al., 1999; Rogers et al., 2005; Schäfer et al., 2003) and their emission factors are reported in the literature and measured by aircraft manufacturers. International databases for emission factors have been established, e.g. Engine Exhaust Emission Database operated by the International Civil Aviation Organisation (ICAO) hosted by the European Aviation Safety Agency (EASA, 2012) for jet engines or the Swedish FOI (www.foi.se, for turboprops). Several of the more traditional pollutants are regulated by emission limits and air quality standards. 
As for other combustion processes the nanoparticle emissions originate mainly from combustion products of the aircraft fuel or even unburned fuel, lubricants and condensates of low volatile vapours in the exhaust. However, much less information exists in the literature on PNCs and so far no limit values or standards have been established, neither for aircraft emission factors nor ambient concentrations. However health concerns related to nanoparticles have triggered several large studies investigating particle number emissions e.g. the European project PartEmis (Petzold et al., 2003) or the Aircraft Particle Emission eXperiment (APEX) in the US (Kinsey et al., 2010) as well smaller local studies (Ellermann et al., 2011; Herndon et al., 2005; Mazaheri et al., 2009).

\subsubsection{Nanoparticle emissions and their characteristics}

Aircraft emissions are usually characterized in the different operating modes of the landing/take-off (LTO) cycle. As expected emissions and emission index (EI) (expressed as emission per fuel unit) are often found to be very dependent on operating conditions and thrust level as engine start-up, idle, taxi, take off, cruise, and approach (Herndon et al., 2005; Mazaheri et al., 2009). Lower-power operating conditions produce more $\mathrm{CO}$ and hydrocarbons than high power operations, while particle and $\mathrm{NO}_{\mathrm{x}}$ emissions have a nearly linear relationship with engine thrust levels (Mazaheri et al., 2009). The measured particle number emission factor, PNEF $\left(\mathrm{kg}^{-1}\right.$ fuel) from sampling plumes of aircrafts at different airports is in the range $10^{15}-10^{17}$ $\mathrm{kg}^{-1}$ fuel (Herndon et al., 2005; Kinsey et al., 2010; Mazaheri et al., 2009; Zhu et al., 2011). More specific numbers and references regarding aircraft emission are given in Table 1.

Fuel properties especially sulphur content have a significant impact on the emissions. Aircraft fuel has still much higher sulphur content, e.g. 900 ppm (Ellermann et al., 2011) or 50-1270 ppm (Petzold et al., 2003), compared to road vehicle fuels leading to high $\mathrm{SO}_{\mathrm{x}}$ emissions with large potential to form nanoparticles via nucleation of sulphuric acid. Petzold et al. (2003) observed the formation of high numbers of sub10 -nm particles for fuels with high sulphur content. Also the PNEF increased from low to high sulphur content by a factor of 2-3. Kinsey et al. (2010) measured an exponential and linear increase in particle number and mass emissions, respectively, with increasing sulphur content. Such a relationship has been reported consistently in the literature (Agrawal et al., 2008a; Schröder et al., 1998). This is mainly due to the likely connection of sulphuric acid created from the sulphur content in the fuel with nucleation and condensation (Jones et al., 2012; Wåhlin, 2009).

The measured size distribution of particles from aircraft is dominated by small particles with diameters of 10-40 nm (Buonanno et al., 2012b; Kinsey et al., 2010; Mazaheri et al., 2009; Rogers et al., 2005; Zhu et al., 2011). Herndon et al. (2008) observed a mode at about $65 \mathrm{~nm}$ associated with take-off plumes and a smaller mode (about $25 \mathrm{~nm}$ ) for idling plumes.

\subsection{Municipal solid waste (MSW) incineration}

\subsubsection{Source characteristics and nanoparticle formation}

According to the European Waste Incineration Directive (2000/76/EC), the incineration plants must be designed to ensure that the flue gases reach a temperature of at least $850{ }^{\circ} \mathrm{C}$ for 2 seconds to ensure a complete combustion of toxic organic substances. Despite undergoing such a high temperature, a range of particles, starting 
from nanosize up to $75 \mu \mathrm{m}$ can still be detected in the flue gases generated as a result of MSW incineration. The nanoparticles are formed in numerous ways such as (i) homogeneous nucleation of heavy metal vapour after the combustion when gaseous products travel through the flue gas system, followed by their growth through coagulation and condensation of other vaporised materials onto fly ash particles (Carbone et al., 2008; Harrison and Hester, 1994), and (ii) combustion of nanocomposites that remain unsorted during the waste sorting prior to the incineration site (Roes et al., 2012). Besides the above, the nanoparticles can also become airborne from the waste management site where the delivery trucks, trains or containers dump the waste into the containers; although the focus of this article remains limited to stack emissions only. As pointed out by a recent study (Roes et al., 2012), some nanocomposites containing only carbon are fully combusted and converted into $\mathrm{CO}_{2}$, without producing nanoparticles. On the contrary, some of the nanocomposites are released to the environment with the flue gases and others (e.g. $\mathrm{CaCO}_{3}$ ) are destroyed as a result of oxidation, reduction, pyrolysis or a chemical reaction but still end up with the formation of new nanoscale oxides (e.g. $\mathrm{CaO}$ in this case). In addition, new nanoparticles are continuously formed in the form of metal oxides, salts or soot particles regardless of nanocomposites in the waste (Roes et al., 2012). The resulting PNCs depend on the residence time of the flue gas in the combustion system and the treatment system deployed. For instance, the shorter the residence time, less are the opportunity for particles to coagulate and grow, and vice versa (Linak and Wendt, 1993).

\subsubsection{Nanoparticle emissions and their characteristics}

The concentrations of nanoparticles can vary $\left(\sim 10^{5}-10^{7} \mathrm{~cm}^{-3}\right.$ before the flue gas treatment) depending on various factors such as the combustible material and flue-gas treatment system deployed in MSW incinerator plants (Buonanno et al., 2009a; Buonanno et al., 2011; Shi and Harrison, 1999; Urciuolo et al., 2008). As an approximation, 1 tonne of conventional waste can produce a total of $\sim 3.76 \times 10^{15}$ nanoparticles, with about 0.1-1 times of further addition from nanocomposites incineration (Roes et al., 2012).

However, the stack emissions are observed to be much smaller due to the removal of nanoparticles by the treatment systems compared with those prior to the flue gas treatment. The larger sized particles tend to settle prior to the flue gas, but some nanoparticles escape through the off-gas treatment systems. For nanoparticles, studies present varying results on the efficiency of treatment systems and indicate a need for further measurements. For example, Buonanno et al. (2011) measured the PNCs before $\left(2.4 \times 10^{7} \mathrm{~cm}^{-3}\right)$ and after $\left(3.5 \times 10^{2} \mathrm{~cm}^{-3}\right)$ passing through the fabric filter which represent a removal efficiency over $99.99 \%$. For instance, Buonanno et al. (2009a) measured PNCs in the $30 \mathrm{~nm}$ to $10 \mu \mathrm{m}$ size range in the stack of a MSW incinerator in the range $1-2\left(\times 10^{5}\right) \mathrm{cm}^{-3}$ with a peak at about $80 \mathrm{~nm}$ after the flue gas passed through the treatment systems (i.e. selective non-catalytic reduction, electrostatic precipitator spray absorber system and fabric filter) in 2007. Two years later, the authors measured the PNCs in the 3-800 nm range and found the maximum values reported in the stack gas were $2 \times 10^{3} \mathrm{~cm}^{-3}$ with a peak at about $90 \mathrm{~nm}$ compared with the maximum values up to $2.7 \times 10^{7} \mathrm{~cm}^{-3}$ with a peak about $150 \mathrm{~nm}$ before the treatment by the high efficiency fabric filters (Buonanno et al., 2011). The arguments put forward for this notable removal was that the fabric filters, which are deployed for 
eliminating total dust from the flue gas, act on the mechanism of inertial and diffusive deposition that is also significantly important for removal of particles below $100 \mathrm{~nm}$ in size (Hinds, 1999; Kumar et al., 2008). Likewise, Maghun et al. (2003) measured the PNCs in the $17 \mathrm{~nm}-30 \mu \mathrm{m}$ size range in the flue gas of a MSW incineration plant (23 MW) at two sampling points in the flue-gas duct $\left(700\right.$ and $\left.300{ }^{\circ} \mathrm{C}\right)$ as well as in the stack gas $\left(80{ }^{\circ} \mathrm{C}\right)$. The PNCs were found in the range of $\sim 10^{5}-10^{6} \mathrm{~cm}^{-3}$ before the treatment by wet electrostatic dust precipitator compared with of the order of $\sim 10^{3}$ $\mathrm{cm}^{-3}$ after the treatment.

Studies generally indicate a large variation in the generation of PNCs. Before the treatment the PNCs can vary in the $10^{5}-10^{8} \mathrm{~cm}^{-3}$ range depending on the fuel types used which has been found to decrease to $\sim 10^{3}-10^{5} \mathrm{~cm}^{-3}$ depending the efficiency of the flue gas treatment system used on a particular plant. The latter range is similar to that found in urban air, deriving mainly from road traffic.

\subsection{Domestic biomass burning \\ 4.6.1 Source characteristics and nanoparticle formation}

Nearly 3 billion people worldwide rely on solid biomass fuels for household cooking and space heating, and about $50-60 \%$ of them often use the fuels in poorly ventilated indoor situations (Northcross et al., 2012). Particles produced by biomass burning can affect the global radiation budget by both direct (albedo increase) and indirect (cloud formation) effects (Andreae and Crutzen, 1997; Lee et al., 2010). Biomass burning, as one of the largest sources of accumulation mode particles globally, has been closely studied in many forms including laboratory burns, in situ experiments, remote sensing, and modelling (Reid et al., 2005). It is well established that wood-burning stoves and fireplaces as well as wildland and agricultural fires emit significant quantities of known health-damaging pollutants, including several carcinogenic compounds causing adverse effects on human health via several pathways (e.g. lung function, asthma, cancer) leading to 1-2 million premature deaths per year globally (Naeher et al., 2007; WHO, 2002).

Solid biomass fuels consist mainly of carbon, hydrogen and oxygen that get converted to about $90 \%$ into $\mathrm{CO}_{2}, \mathrm{CO}$ and water. However, as with fossil fuels, incomplete combustion of biomass also produces both gaseous and particulate air pollution, such as particles in the nanosize range, fine and coarse particles, $\mathrm{CO}, \mathrm{VOC}, \mathrm{NO}_{2}$ and formaldehyde (Bølling et al., 2009). In particles from biomass burning a number of trace species as metals ( $\mathrm{Na}, \mathrm{K}, \mathrm{S}, \mathrm{Zn}, \mathrm{Ti}, \mathrm{Fe}$ etc.) and inorganic ions (nitrate, sulfate etc.) are reported (Kleeman et al., 1999; Tissari et al., 2008) as well as polycyclic aromatic hydrocarbons (PAH) both in the particle and gas phase (Glasius et al., 2008; Hedberg et al., 2002; Schauer et al., 2001). Biomass burning includes a number of other sources such as wild land fires and agricultural residue or waste burning (see Section 4.7), power generation (Section 4.8), prescribed burning and residential wood combustion (covered here) (Hosseini et al., 2010). A large body of literature and review articles is available on the characteristics of the emissions in terms of particle mass and chemical composition (Andreae and Merlet, 2001; Guofeng et al., 2012; Reid et al., 2005), while articles including particle number emissions are still relatively sparse (see references later in this Section 4.6).

The number and size distributions of particles produced by biomass burning differ substantially depending on the combustion phase (ignition, flaming and smouldering), 
fuel condition (live, dead and varying moisture content), fuel configuration (dense vs. light; softwood vs. lightwood; plain vs. sloped terrain), fuel types (foliage, log, branch) and measurement (or experimental) conditions applied (Hosseini et al., 2010). Since the production of nanoparticles depend significantly on combustion characteristics, it is worth mentioning that unlike 'flaming combustion', 'smouldering combustion' is the least efficient with the limited oxygen, producing most smoke (and larger sized particles) per unit of fuel consumed. Hence the nanoparticles emitted during the smouldering combustion have a higher fraction of volatile species than those generated during the flaming combustion (Maruf Hossain et al., 2012). Similarly, Hueglin et al. (1997) investigated the morphology and size distribution of wood combustion particles and found that the amount of combustion air supply had strong impact on the particle size distribution and the emission of particle bound PAH. Tissari et al. (2008) measured the particle and gaseous emissions from wood combustion finding increases of 3.5 times for $\mathrm{CO}, 14$ times for VOC and 6 times for $\mathrm{PM}_{1}$ during smouldering combustion compared to normal combustion. The emissions of inorganic compounds ('fine ash') and particle number emissions were lower from smouldering combustion compared to normal combustion. According to electron microscopy analyses, the observed ultrafine $(<100 \mathrm{~nm})$ ash particles seemed to occur mainly as separate spherical or irregularly shaped particles but not as agglomerates. Large agglomerates were found to contain mainly carbon and are considered to be primarily soot particles. The ultrafine mode in the particle number distributions was determined mainly by the amount of released ash forming material in combustion, and the shifting of particle size during different combustion conditions was determined by the amount of condensed organic vapour in the flue gas (Tissari et al., 2008).

\subsubsection{Nanoparticle emissions and their characteristics}

As for the case with nanoparticles released from the combustion of fossil fuels (Carpentieri and Kumar, 2011; Dall'Osto et al., 2011), number and size distribution vary both temporally and spatially due to the influence of transformation processes such as nucleation, coagulation and condensation within and downstream of the biomass burning. The key factors causing this uncertainty are the sampling locations, sampling temperature, dilution ratios, combustion conditions and fuel type (Lipsky and Robinson, 2006). While some have found unimodal distributions (Wardoyo, 2007), others have reported bimodal (Maruf Hossain et al., 2012) and even both types of distributions (Zhang et al., 2012) from the combustion of different types of wood. Some studies might miss a coarse mode peak due to the limitations of the particle size range covered by the instruments used. Other studies (Zhang et al., 2012) have also witnessed the gradual conversion of bimodal distributions into unimodal during the last few minutes of the burning period. For instance, Hosseini et al. (2010) tested 8 different wetland fuels and found a major mode of particle size distributions varying in the 29 to $52 \mathrm{~nm}$ size range. They noticed unimodal particle size distributions for most fuel types during the flaming phase and strongly bimodal during the smouldering phase. Hays et al. (2002) also found unimodal distributions during their open fire/combustion of 6 fine (foliar) fuels common to fire-prone U.S. ecosystems. Their experiments mimicked the real world open fire conditions and found geometric mean diameters (GMD) between 100 and $200 \mathrm{~nm}$. Likewise, Chakrabarty et al. (2006) measured the particle size distribution from laboratory combustion of 8 different fuels and measured a count mean diameter (CMD) varying between 30 and $70 \mathrm{~nm}$ for dry fuels which increased to between 120 and $140 \mathrm{~nm}$ for wet fuels (tundra core and 
Montana grass). Further, Hedberg et al. (2002) tested birch wood, which is a widely used biomass fuel for wood stove combustion in Swedish household appliances. They kept the fuel load constant during all their six experiments and found quite constant number size distributions during the start-up phase for the smallest mode, with a GMD of $52 \mathrm{~nm}$. The size-dependent concentrations were more variable for the intermediate and smouldering phases, while the GMD of the two modes were found to be stable at $\sim 26-28 \mathrm{~nm}$ and $125-129 \mathrm{~nm}$, respectively. A recent study by Zhang et al. (2012) characterised the emissions of a locally grown wood in Guizhou province of China. They measured the number and size distributions in the 10-10,000 nm range at about 2-3 $\mathrm{m}$ away from the wood fire in a kitchen and measured bimodal distributions, which were found to be peaking at about $10-20 \mathrm{~nm}$ and $40-50 \mathrm{~nm}$, respectively. The PNCs ranged between 1.8 and $3.7 \times 10^{5} \mathrm{~cm}^{-3}$ depending on the burning periods.

For fast burning (flaming combustion) of the five common tree species found in South East Queensland (Australia) forests, the PNEF were found to be $3.3-5.7 \times 10^{15} \mathrm{~kg}^{-1}$ for wood and $0.5-6.9 \times 10^{15} \mathrm{~kg}^{-1}$ for leaves and branches, with a CMD of $60 \mathrm{~nm}$ during ignition and $30 \mathrm{~nm}$ for the rest of the burning process (Wardoyo et al., 2006). For slow burning (smouldering combustion) the PNEF were found to be $2.8-45 \times 10^{13}$ $\mathrm{kg}^{-1}$ for wood and $0.5-9.3 \times 10^{13} \mathrm{~kg}^{-1}$ for leaves and branches, with a CMD of 120, 60 and $40 \mathrm{~nm}$ during ignition, flaming and smouldering phases, respectively (Wardoyo et al., 2006). Similarly, Hedberg et al. (2002) measured the PNCs from birch wood burning at approximately $1 \mathrm{~m}$ away from the stove. Median PNCs in the 3-920 nm range, which were measured using a DMPS over consecutive 10 min periods after fire start-up excluding the first $10 \mathrm{~min}$, varied in the range $1.5-8 \times 10^{7} \mathrm{~cm}^{-3}$. They found the emission factors in the range $1.3-97 \times 10^{13} \mathrm{~kg}^{-1}$ wood.

\subsection{Forest fires and burning of agriculture residues 4.7.1 Source characteristics and nanoparticle formation}

Burning of agriculture residues (e.g. rice and wheat straw) and forest fire (e.g. hardwood such as oak and softwood such as pine) emit notable emissions of PM (including nanoparticles) to the atmospheric environment. These can adversely affect both the public health (Bølling et al., 2009) and the radiation balance since nanoparticles acts as a cloud condensation nuclei (Petters et al., 2009). Forest wildfires have been on the rise in recent decades, as evident by recent reports of higher large-wildfire frequency, longer wildfire durations, and longer wildfire seasons in western US (Bowman et al., 2009; Westerling et al., 2007). Pollution episodes associated with wildfire emissions affect atmospheric chemistry and radiative properties of particles (Hodzic et al., 2007; Petters et al., 2009) due to the release of fine particles and trace gases in high amounts which are also precursors for ozone. Consequently, wildfires lead to the deterioration of air quality at regional and local scales causing serious health concerns (Bølling et al., 2009). Long-range transport of biomass plumes is an important factor to control the spatial and temporal variability of properties and atmospheric load of particles (Petzold et al., 2007). For example, Fiedler et al. (2011) predicted that during transport across the Atlantic, the aged African smoke particles have a potential to become activated already at very small supersaturation $(0.05 \%)$ which would allow them to act as cloud condensation nuclei in maritime stratiform cloud formation. 
In flaming combustion (higher temperature), particle formation begins with the creation of condensation nuclei such as PAH from ejected fuel gases as well as from a variety of soot-like species (Reid et al., 2005, and references therein) onto which condensable vapours can condensate. In smouldering combustion (lower temperature), the mass fraction of soot in smoke particles is very low, and particles are largely formed by the condensation of volatilised organics on any available particles or surfaces (Reid et al., 2005).

\subsubsection{Nanoparticle emissions and their characteristics}

Reid et al. (2005) give an comprehensive review of biomass burning emissions including fundamentals on particle formation, physical properties (size and morphology), chemical composition, thermodynamic properties and emission factors (in units of $\mathrm{g} / \mathrm{kg}$ dry fuel mass burned). A fuel carbon content of $45 \%$ is usually assumed in order to derive emission factors from emission ratios (Andreae and Merlet, 2001). Fresh smoke particles are composed of $50-60 \%$ organic carbon and $\sim 5-10 \%$ black carbon with count median diameters in the range of 100-160 nm peaking at $\sim 130 \mathrm{~nm}$ and volume median diameter in the range of 250-300 nm (Reid et al., 2005). Petzold et al. (2007) measured the aged forest fire plume using an aboard research aircraft and reported that particle size distributions were characterised by a strong internally mixed accumulation mode centred at 250-300 nm, and all particles contained a non-volatile core.

While emission factors for grassland and savanna are relatively well known very large uncertainty still exists in emission factors (both for mass and number) for boreal, temperate, and some tropical forests. Most of the published emission factors concern $\mathrm{PM}_{10}$ and $\mathrm{PM}_{2.5}$ (Reid et al., 2005; Yokelson et al., 2007). Sinha et al. (2003) measured PNCs in the savanna fire plumes using an aboard research aircraft over southern Africa (SAFARI 2000 project). The PNEFs $(30 \pm 17) \times 10^{15} \mathrm{~kg}^{-1}$ were $3-14$ times greater than the laboratory value $\left(3.4 \times 10^{15} \mathrm{~kg}^{-1}\right)$ given by Andreae and Merlet (2001). Guyon et al. (2005) obtained the average PNEF of $1.5 \times 10^{15} \mathrm{~kg}^{-1}$ for the tropical forest.

A recent review by Janhäll et al. (2010) focuses on particle number and mass emission factors from forest, savanna and grass fire emissions. Emission factors were related to fuel type, burning conditions in terms of modified combustion efficiency (MCE) and $\mathrm{PNC} / \mathrm{CO}$ emissions ratios. Fresh emissions are found to have CMDs of about $120 \mathrm{~nm}$ and PNEF in the range $(1.2-3.4) \times 10^{15} \mathrm{~kg}^{-1}$ and $\mathrm{PNC} / \mathrm{CO}$ emission ratios of $(34 \pm 16)$ $\mathrm{cm}^{-3} \mathrm{ppb}^{-1}$.

Like domestic wood burning (Section 4.6), the combustion of agriculture residue also produces varying particle number and size distributions. A recent study investigated emissions characteristics of particles in the $20-10,000 \mathrm{~nm}$ size range of three combustion conditions (open fire, flaming and smouldering) in laboratory simulations (Maruf Hossain et al., 2012). They found unimodal distributions for rice straw burning in all three combustion conditions. Also a positive shift in the particle mode diameters was observed, peaking at $\sim 53,88$ and $141 \mathrm{~nm}$ for the open burning, smouldering and flaming combustion, respectively. Likewise, Hays et al. (2005) observed unimodal distributions for particles in the 10-400 nm size range during their combustion experiments on wheat straw. Further experiments of Maruf Hossain et al. (2012) reported identical, bimodal, distributions for oak and pine wood combustion. 
Although distinct differences were observed during the flaming and smouldering combustion; flaming produced a large mode at about $200 \mathrm{~nm}$ for both woods compared with smouldering producing a relatively large mode at $\sim 500 \mathrm{~nm}$. One of the key reasons offered for this varying size distributions was the presence of over 200 OC compounds which have a broad range of melting points (less than $0^{\circ} \mathrm{C}$ to more than $250^{\circ} \mathrm{C}$ ), potentially facilitating the process of attachments with other particles (Hays et al., 2005).

\subsection{Power plants}

\subsubsection{Source characteristics and nanoparticle formation}

Power plants combust a blend of fuels, including coal and biomass (e.g. wood, waste and agriculture residue) and hence differ the formation mechanism and size distributions of nanoparticles. Since nanoparticle emissions from the biomass burning have been covered in Sections 4.6 and 4.7, the focus of this section remains on coalfired power plants.

Pulverised coal combustion generally occur in air-blown, oxygen enriched, furnaces which produces both the nanoparticles and PM in abundance (Carbone et al., 2010a). While the supermicron particles are formed via fragmentation, coagulation, or coalescence during pulverized coal combustion (Wang et al., 2008), submicron particles are formed through the vaporisation of metals in the form of refractory oxides, their subsequent heterogeneous or homogeneous nucleation and growth via condensation, sintering or condensation (Carbone et al., 2010a). Chemical analysis of coal-fired power plants induced particles indicate totally different chemical composition of nanoparticles compared with those of fine and coarse fraction (Wang et al., 2008), with high concentrations of easily vaporising elements ( $\mathrm{Na}$ and $\mathrm{S}$ ) in nanosize range that promote condensation/nucleation formation mechanism (Kulmala et al., 2004; Kumar et al., 2011a). The enrichment of such metals has also been reported by other studies focusing on the sampling of stack gas emissions from the coal-fired power plants (Yoo et al., 2005), supporting the vaporisation-condensationnucleation formation route. The elements such as chlorine promotes the formation of volatile compounds, leading to multimodal particle size distributions (Carbone et al., 2010b). Despite the fact that coal-fired power plants produce about $41 \%$ of worldwide electricity (2006 data; http://www.worldcoal.org/coal), there is yet a handful of studies on nanoparticles emissions and their size distributions.

\subsubsection{Nanoparticle emissions and their characteristics}

Nanoparticle emissions have been studied through the laboratory, pilot- and full-scale coal combustor plants (Table 1). Since coal-power plants are largely associated with PM emissions, flue gas treatment devices are mostly applied at the exit point of emissions (Tian et al., 2012). The devices such as the electrostatic precipitator (ESP) are capable of removing over $99 \%$ of the PM from the flue gases but their efficiency decreases with the decrease in particle size and hence are extremely less effective in removing nanoparticles due to their partial or insufficient diffusion charging (see also Section 4.5). Furthermore, the coagulation rates of both carbonaceous and metal particles below $10 \mathrm{~nm}$ diameter drops significantly at high temperatures due to their sticking coefficient for both coagulation and adhesion being orders of magnitudes lower than those expected for larger size particles such as soot (D'Alessio et al., 2005), providing them the ability to survive exhaust conditions and 
to sneak into the ambient atmosphere in notable quantities (Carbone et al., 2008; Carbone et al., 2010a).

Most studies are in consensus that the PNDs from coal-power plants are multimodal and produce notable quantities of PNCs $\left(\sim 10^{8}-10^{10} \mathrm{~cm}^{-3}\right)$ in nanosize range before the flue gas treatment devices. After the treatment, these concentrations can still remain more than 2 orders of magnitude larger (i.e. up to $\sim 10^{5} \mathrm{~cm}^{-3}$ ) over the typical rural background PNCs (i.e. up to $\sim 10^{3} \mathrm{~cm}^{-3}$ ) depending on the efficiency of the flue treatment devices and quality of coal burned. For instance, Wang et al. (2008) studied a $100 \mathrm{MW}$ full scale coal-fired power plant in China. They measured the PNCs in the 5.6-560 nm range at the outlet of a twin-chamber ESP as $6 \times 10^{8} \mathrm{~cm}^{-3}$ which were $\sim 2$ orders of magnitude larger than the unusually high PNCs $\left(3.17 \times 10^{6} \mathrm{~cm}^{-3}\right)$ in surrounding ambient air. Likewise, Li et al (2009) measured the PNDs in the 17-1000 $\mathrm{nm}$ range from a $160 \mathrm{~kW}$ pilot-scale coal combustor which was equipped with a single-wire tubular ESP to collect fly ash particles. The typical PNCs at the ESP inlet were of the order of $\sim 10^{8} \mathrm{~cm}^{-3}$. The ESP removed over 3 orders of magnitude PNCs. The authors also observed increased penetration through the ESP with decreasing particle size below $70 \mathrm{~nm}$ due to their insufficient or partial charging.

Closer inspection of the measured PNDs from the coal combustor plants indicates two or sometimes three modal peaks, mainly in sub-100 nm range, indicating the abundance of PNCs in UFP size range. For instance, Wang et al. (2008) measured bimodal distributions in the pre-treated flue gas from a full-scale power plant peaking at $~ 9.31$ and $60 \mathrm{~nm}$; Zhao et al. (2010) observed peak PND diameters in the 10-20 nm and 200-300 nm range. Zhuang and Biswas (2001) found the geometric mean particle size in the 63-84 $\mathrm{nm}$ range during a bench-scale pulverized coal combustor study. $\mathrm{Li}$ et al (2009) found a dominant peak of PNDs at $\sim 75 \mathrm{~nm}$ during a pilot-scale study. Other pilot-scale studies observed peak of PNDs in the 40-50 nm range for medium sulphur bituminous coal combustion (Chang et al., 2004), and at $\sim 80 \mathrm{~nm}$ for Power River Basin subbituminous coal combustion (Senior et al., 2000). Irrespective of whether the coal combustion is studied through bench-, pilot-, or full-scale studies with any type of coal (e.g. pulverised bituminous, subbituminous), the dominant peaks of PNDs below $100 \mathrm{~nm}$ range indicate a clear consensus that a significant amount of tiny sized PNC are produced and more efficient flue gas treatment devices are needed to control their direct, and precursor gases and elemental species, emissions.

\subsection{Cigarette smoking}

\subsubsection{Source characteristics and nanoparticle formation}

Environmental tobacco smoke from waterpipes, cigars or cigarettes produces a variety of harmful pollutants which can affect both the health of smokers and nonsmokers (Klepeis et al., 2003). As a consequence, smoking of cigarettes has been banned in many public places of the world which has resulted in significant reductions in concentrations of ambient nanoparticles. For instance, Valente et al. (2007) studied the indoor air quality in 40 public places before and after the smoking ban in all indoor public places in Italy. They noticed a significant decrease in mean PNCs of $7.7 \times 10^{4} \mathrm{~cm}^{-3}$ to $3.8 \times 10^{4} \mathrm{~cm}^{-3}$ after 3 months in studied hospitality venues. The scope of this section is limited to emissions from cigarettes only. This does not imply that the waterpipes or cigars do not produce many nanoparticles. In fact they do as studies have found up to 5 times more particle number emissions from a single waterpipe smoking session compared with those emitted by a single cigarette (Daher et al., 
2010). Particle mass based studies also confirm that the equivalent total particle emission rate could be in the range $0.2-0.7 \mathrm{mg} \mathrm{min}^{-1}$ for cigars and $0.7-0.9 \mathrm{mg} \mathrm{min}^{-1}$ for cigarettes (Klepeis et al., 2003). The reason to keep our discussions limited to cigarettes is mainly the brevity of the article and the fact that these are the dominant source of tobacco combustion. Cigarettes produce smoke through both sidestream (i.e. undiluted plume coming from the cigarette smouldering end) and mainstream (i.e. undiluted puff of smoke drawn through cigarette and exhaled by the smoker). The discussions below are focused towards the sidestream emissions.

Numerous physicochemical processes takes place inside a burning end of a cigarette that provide an oxygen-deficient, hydrogen-rich environment with temperatures up to $\sim 950^{\circ} \mathrm{C}$ (Baker, 1980). This process produces thousands of chemicals distributed between both the gas and aerosol phase. Significant amounts of nanoparticles are formed due to the gas-to-particle conversion from the interaction of cigarette smoke with the ambient air. The smoke is formed due to incomplete combustion of tobacco in the presence of varying oxygen and temperature levels and additive ingredients. The extent of nanoparticle emissions is evident from the fact that one cigarette can typically produce particles of the order of $\sim 10^{11}-10^{12} \mathrm{~min}^{-1}$ or a total of $\sim 10^{12}$ cigarette $^{-1}$ (see Section 4.9.2 and Table 1).

\subsubsection{Nanoparticle emissions and their characteristics}

Emissions from cigarettes are difficult to characterise with accuracy because of the complexities of the cigarette combustion process (e.g. varying temperature and oxygen levels) and interaction of the particle plume with the ambient air (Morawska et al., 1997). Further complexities are raised by the units used to measure emissions which make the direct comparison of the results difficult. Some studies characterise

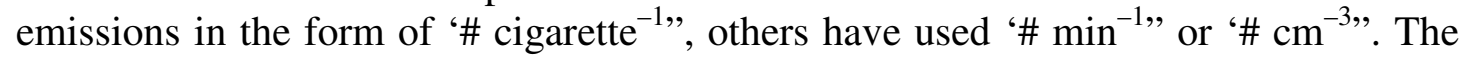
first two units are comparable when duration of smoking was known.

Wu et al. (2011) measured number and size distributions of particles during cigarette smouldering using an SMPS. The mean PNEF in UFP size range were found to be $3.36 \pm 0.34 \times 10^{11} \mathrm{~min}^{-1}$, with only $\sim 7 \%$ standard deviation for number concentrations between the five popular brands of cigarettes used. Other studies reported comparable emissions to that reported by Wu et al. (2011) such as $3.8 \times 10^{11} \mathrm{~min}^{-1}$ (Afshari et al., 2005) and $1.91 \pm 1.92 \times 10^{11} \mathrm{~min}^{-1}$ (He et al., 2004). In terms of total particle number emitted per cigarette, Daher et al. (2010) measured $0.64 \pm 0.19 \times 10^{12}$ cigarette $^{-1}$ averaged over the 4 repetitive cigarette trials. Similar results were reported by a recent study that found a range of total particle number emissions over a wide range of experiments as $1-5.1 \times 10^{12}$ cigarette $^{-1}$ (Wallace and Ott, 2011).

Few studies have characterised cigarette emissions in terms of elevated concentrations in indoor environments. For instance, He et al. (2004) measured PNCs as $2.7 \times 10^{4} \mathrm{~cm}^{-}$ ${ }^{3}$ which were about 1.5 times over the background values. Morawska et al. (2003) reported elevated concentrations in the range $2 \times 10^{5} \mathrm{~cm}^{-3}$ to $3.5 \times 10^{6} \mathrm{~cm}^{-3}$. However, the numbers of cigarette smoked in test rooms were not clear in both these studies. In a study by Hussein et al. (2006), smoking of one cigarette in the living room increased PNCs about 6 times to $3.6 \times 10^{4}$ over the base-line PNCs. Three cigarettes were continuously burned for about 10 minutes during the experiments by Afshari et al. (2005) which resulted in maximum PNCs up to $2.1 \times 10^{5} \mathrm{~cm}^{-3}$ that lasted for about 20 min and took about 300 min to return back to background PNCs. 
Despite different origins, measurement techniques used and combustion conditions available for cigarette smouldering, particle size distributions measured by studies seem to be in consensus with each other. Results indicate a peak in size distributions at about $100 \mathrm{~nm}$, with a notable amount of PNCs over the $100 \mathrm{~nm}$. For example, Wallace and Ott (2011) measured a peak at about $100 \mathrm{~nm}$, and an increase in ambient PNCs from the background $0.6 \times 10^{3} \mathrm{~cm}^{-3}$ to $4.1 \times 10^{4} \mathrm{~cm}^{-3}$ in the $100-400 \mathrm{~nm}$ size range with an indication of a substantial portion of particles over $100 \mathrm{~nm}$ range. Morawska et al. (1997) found peak values at slightly lower sizes (i.e. between 60 and $90 \mathrm{~nm}$ ) while Wu et al. (2011) and Daher et al. (2010) found peaks at sizes above 100 nm (i.e. at $\sim 110$ and $132 \pm 11 \mathrm{~nm}$, respectively).

\subsection{Cooking (restaurant/residential) \\ 4.10.1 Source characteristics and nanoparticle formation}

Cooking is not a direct outdoor source but this often raises concentrations of air pollutants, including nanoparticles, during cooking in indoor environments. This indoor concentration escapes to outdoor ambient environments via ventilation (Schauer et al., 1996b). In this manner, each house acts as an important 'point source' for outdoor emissions. Cooking activities have been investigated both in residential kitchens (He et al., 2004; Morawska et al., 2003; Wan et al., 2011), commercial restaurants (Buonanno et al., 2010; Lee et al., 2001) and open uncontrolled environments such as barbeques (Dennekamp et al., 2001). A large body of literature exist on this topic but a brief overview pertaining to nanoparticle emissions from gas and electric stoves based cooking is included in this chapter. Cooking using solid fuels and biomass (e.g. coal, wood, animal dung, crop residues) are not covered here to avoid repetition (see Section 4.6-4.8).

Nanoparticles are formed, as in other situations, due to the incomplete combustion of fuel, oil, and food. The cooking fumes contain numerous organic and inorganic compounds that lead to nanoparticle formation through gas-to-particle conversion (Wallace et al., 2004). Quantities of emissions depend heavily on type of cooking in European, Asian, Australian and American continents (Buonanno et al., 2010; Zhang et al., 2010) and factors such as intensity of cooking, quantity and type of ingredients used, characteristics of sampling sites, height and location of particle sampling instrument, type of instruments used for nanoparticle monitoring, building geometry, ventilation type (natural or mechanical) and rates of cooking shelters, indoor temperature, relative humidity, quantity of fuel burned and oil used (See and Balasubramanian, 2006).

\subsubsection{Nanoparticle emissions and their characteristics}

As for emissions from sources such as cigarettes, characterising the nanoparticle emissions from cooking and making their direct comparison is a challenging task. This is mainly because of diverse cooking and measurement conditions, besides their measurements in a variety of units (i.e. emissions per minute in $\# \min ^{-1}$ or elevated concentrations over background during a cooking activity in \# $\left.\mathrm{cm}^{-3}\right)$.

Studies indicate that the indoor PNCs can increase between 1 and 30 times over the background values during a range of cooking activities, which can lead to indoor concentration values to about 15 times higher than those observed $\left(7.4 \times 10^{3} \mathrm{~cm}^{-3}\right)$ in outdoors (He et al., 2004). This increase, as expected in the case of stir frying, has 
been reported up to about 85 times higher (See and Balasubramanian, 2006). For instance, this study found PNC levels in the $8-10,000 \mathrm{~nm}$ size range to increase during the cooking hours to $7.7 \times 10^{5} \mathrm{~cm}^{-3}$ over those $\left(9.1 \times 10^{3} \mathrm{~cm}^{-3}\right)$ during the noncooking hours. Another recent study by Zhang et al. (2010) reported similar results and found the average background PNCs $\left(3.7 \times 10^{3} \mathrm{~cm}^{-3}\right)$ to increase rapidly to $3.6 \times 10^{5} \mathrm{~cm}^{-3}$ after frying chicken. They also observed a difference of about 45 -fold (i.e. $1.3 \times 10^{4}$ to $6.0 \times 10^{5} \mathrm{~cm}^{-3}$ ) for a range of Indian (rice, eggs, vegetables, chicken), Italian (pasta, vegetables), Chinese (shrimp and vegetable) and American (fried chicken) cooking activities. Stir frying, which is generally preferred in Chinese cooking, produces many more particles than other cooking methods (Li et al., 1993), as is the case with cooking using a gas stove (e.g. $5.6 \times 10^{6} \mathrm{~cm}^{-3}$ ) compared with an electric stove (e.g. $1.1 \times 10^{6} \mathrm{~cm}^{-3}$ ) (Dennekamp et al., 2001). PNCs are much lower during boiling compared with the highest levels during frying. The PNCs in the ultrafine size range were found to be 10-fold and 20-40 fold over the background in the living room and kitchen, respectively, during a study by Wan et al (2011) in naturally ventilated, non-smoking, homes during Chinese-style cooking. A summary of cooking studies reports the maximum PNCs varying between $1.5 \times 10^{6} \mathrm{~cm}^{-3}$ and $5.6 \times 10^{6} \mathrm{~cm}^{-3}$ (Afshari et al., 2005; Hussein et al., 2006; Morawska et al., 2003; Wu et al., 2011).

As seen in Table 1, few studies have computed the emission rates $\left(\# \mathrm{~min}^{-1}\right.$ ) from cooking activities and reflect similar sorts of variations (i.e. ranging within 2 orders of magnitude between $\sim 10^{10}$ to $\sim 10^{12} \mathrm{~min}^{-1}$ ) as those measured through concentration levels $\left(\# \mathrm{~cm}^{-3}\right)$. For instance, $\mathrm{He}$ et al. (2004) measured emission rates in the 15-685 $\mathrm{nm}$ size range and found them varying between 0.35 and $7.3 \times 10^{11} \mathrm{~min}^{-1}$ for a range of cooking activities, with the emissions during stoving and toasting leading the list with $51.4 \times 10^{11} \mathrm{~min}^{-1}$ and $16.7 \times 10^{11} \mathrm{~min}^{-1}$, respectively. Wu et al. (2011) reported even higher variations in emission rates $\left(4.7-148.3 \times 10^{11} \mathrm{~min}^{-1}\right)$ during their measurements of 6 cooking activities, with the peak diameters of size distributions and count mean diameter varying in the range $16.2-36.1 \mathrm{~nm}$, and $19.7-41.4 \mathrm{~nm}$, respectively. Buonanno et al. (2009b) found the particle number emission rates in the range 2.6-3.4 $\times 10^{12} \mathrm{~min}^{-1}$ for grilling cheese, wurstel (pork meat), bacon and eggplant using a gas stove. The ratio of emission rates between gas and electric stoves was found to be 1.3 for grilling $50 \mathrm{~g}$ of bacon.

In summary, while emissions of nanoparticles are a function of food type, cooking contents and fuel used (see also Section 4.10.1), larger PNEFs are generally observed for both gas and electric stoves at higher cooking temperatures (Buonanno et al., 2009b). Similar to gas and electric stove cooking (Dennekamp et al., 2001), boiling has been found to produce lesser particles compared with frying (Zhang et al., 2010). Irrespective of any type of cooking, number and size distributions are generally dominated by the particles below $100 \mathrm{~nm}$, e.g., showing major peak diameters in the range 16.2-36.1 nm (Wu et al., 2011), $21 \mathrm{~nm}$ (Wan et al., 2011), 20-40 nm (Géhina et al., 2008), 30-50 nm (Li et al., 1993), or 22-72 nm (Dennekamp et al., 2001). This also indicates the presence of most of the particles in the lower size range, with $\sim 80 \%$ of total PNCs below $100 \mathrm{~nm}$ (Wan et al., 2011).

\subsection{Secondary formation of nanoparticles 4.11.1 Source characteristics and nanoparticle formation}


Secondary formation through photochemically induced nucleation and condensation of semi-volatile vapours is an important source of nanoparticles, especially in less polluted environments. Nucleation events are frequently observed in all kinds of clean and polluted environments and several theories and mechanisms for nucleation have been suggested and are highly debated in the community (Holmes, 2007; Kulmala et al., 2005; Kulmala et al., 2004). Still the exact mechanism remains a mystery partly due to the limitation of measuring techniques at very low particle sizes. However, sulphuric acid seems to play a crucial role in the nucleation (Sipila et al., 2010).

In parallel to the initial nucleation, the particles need to grow through condensation of supersaturated vapours on the surface of the nucleated particles. It is believed that particle growth often occurs through the condensation of other gases, including organic and inorganic compounds, than those responsible for nucleation (Holmes, 2007). Besides the nucleation particles, the pre-existing aerosol is a competing sink for condensable gases (condensation sink) and causes nucleation to be favoured by clean environments.

The required low-volatility compounds are usually formed by photochemical reactions between gaseous precursor species in the presence of solar radiation. Photochemically induced particle formation is generally observed during the day time under the following conditions: (i) high solar radiation, (ii) an increased wind speed and boundary layer height leading to dilution of pollutants and the consequent decrease of pollutant concentrations, (iii) the input of $\mathrm{SO}_{2}$ from a source different from traffic exhaust emissions (Reche et al., 2011). The major precursor gases playing a role in photochemical nucleation include $\mathrm{SO}_{2}$ (which form particulate sulphate) and oxidation of terpenes and aromatic hydrocarbons (which form secondary organic aerosols) (Alam et al., 2003; Tunved et al., 2006). Another nucleation mechanism is based on iodine oxides (O'Dowd et al., 2002).

\subsubsection{Nanoparticle emissions and their characteristics}

The contribution of particles from nucleation can be very dominant. Over boreal forests particle nucleation leads to a natural background PNC of about 1-2 $\times 10^{3} \mathrm{~cm}^{-3}$ especially in later spring and early autumn (Dal Maso et al., 2005; Tunved et al., 2006). Kulmala et al. (2005) studied particle formation events in six different sites, representing very different air pollution conditions. The estimated source rate of condensable vapours covered a range of four orders of magnitude. Also the peak PNC during a typical nucleation event depended strongly on the type of environment ranging from only about $2 \times 10^{3} \mathrm{~cm}^{-3}$ in Antarctica over about $10^{4} \mathrm{~cm}^{-3}$ in moderate polluted environments to $10^{5} \mathrm{~cm}^{-3}$ in highly polluted environments (Athens and New Delhi; Kulmala et al., 2005). Particle formation events have frequently (up to $36 \%$ of all days) been observed in the rural and urban environment leading to sudden 5-10 fold increase in particle concentrations (Ketzel et al., 2003; Ketzel et al., 2004; Kristensson et al., 2008).

Reche et al. (2011) measured a number of pollutants, including PNCs, in seven selected urban areas covering road traffic, urban background, urban-industrial, and urban-shipping environments from southern, central and northern Europe. They indicated that photochemistry in Mediterranean regions is a significant source of secondary formation, showing a contribution from 64 to $85 \%$ of PNCs during mid- 
day (11:00-14:00 h UTC) in Southern European cities from sources other than vehicles, including photochemistry (though separate contributions from photochemistry was not estimated). They also concluded that the occurrence of $\mathrm{SO}_{2}$ peaks may also contribute to the occurrence of midday nucleation bursts in specific industrial or shipping-influenced areas, although similar levels of $\mathrm{SO}_{2}$ are recorded at several central European sites without yielding nucleation episodes. A more specific study by Pey et al. (2009) for the urban background in Barcelona city attributed 3\% of total PNCs to photochemically induced nucleation.

A number of past studies have investigated this topic comprehensively and have covered various environments such as the free troposphere (Weber et al., 2001), boreal forests (Tunved et al., 2006; Vehkamaki et al., 2004), coastal areas (Lee et al., 2008), Southern Hemisphere (Cheung et al., 2011; Kulmala et al., 2004), continental urban areas (Birmili and Wiedensohler, 2000; Wu et al., 2008), coastal urban areas (Pey et al., 2009; Reche et al., 2011; Rodríguez et al., 2008), as well as South-East Australian (Ristovski et al., 2010) and Eastern Australian regions (Modini et al., 2009). Therefore, only a brief discussion is presented here for the sake of the completeness of the article.

\section{Relative importance of source strengths}

While some of the sources are measured in terms of increased environmental concentrations due to emissions from an individual source, others are measured in the form of emission rates per unit time or number per unit of quantity (e.g. fuel, weight or length) burned (see Section 4 and Table 1). This makes the inter-comparison of source strengths and establishing their relative importance challenging. We have attempted to make the comparison of emissions from individual sources discussed in Section 4 with the most dominant source of nanoparticles (i.e. road vehicles) so that their relative importance can be approximated.

Road-tyre interaction and re-suspension: Road dust has been recognised as a dominant source of $\mathrm{PM}_{10}$ in urban areas, particularly during spring time in Scandinavia, North America and Japan. The $\mathrm{PM}_{10}$ limit value by $\mathrm{EU}$ has been exceeded in many European cities. Dahl et al. (2006) studied ultrafine particle emissions produced by the road/tire interface on a laboratory road simulator. They reported PNEFs in the range $4-30 \times 10^{11} \mathrm{~km}^{-1}$ at speeds of $50 \mathrm{~km} \mathrm{~h}^{-1}$ and $70 \mathrm{~km} \mathrm{~h}^{-1}$ for studded and non-studded tires, respectively. These emissions corresponded to around $0.1-1 \%$ of the exhaust emissions from a vehicle fleet consisting $95 \%$ gasoline and 5\% diesel-fuelled cars, but are the same order of magnitude with the emission factors from new technology light-duty gasoline vehicles.

Construction and demolition: There is only a handful of data available to compare the emissions of building activities with traffic emissions (see Section 4.2). A recent laboratory investigation found total PNCs about $\sim 2.3,5.2,20.4,25.1\left(\times 10^{4}\right) \mathrm{cm}^{-3}$ which were $\sim 2,3,14$ and 17 times over the background during cube crushing, 'wet' recycling, slab demolition and 'dry' recycling, respectively (Kumar et al., 2012c). Our recent study reviewed a total of about 45 sampling locations in 30 different cities within 15 European countries for quantifying levels of roadside PNCs (Kumar et al., 2012a). Average PNCs at the reviewed roadside were found to be $3.8 \pm 3.2 \times 10^{4} \mathrm{~cm}^{-3}$. Comparison of these values suggest that, except concrete crushing processes, the other three process produce $\sim 1.4,5.3$ and 6.6 times larger concentrations close to the source 
when in continuous operation to those compared with typical roadside PNCs. Furthermore, these values are also comparable with, and in some cases up to an order of magnitude larger than, the levels of PNCs generated from road-tyre interactions for different road surfaces at different vehicle speeds (see Section 4.1.3 and Table 1). This suggests that building activities can be an unexpectedly large local source of UFP dust which previously has been ignored (Kumar et al., 2012b).

Ship emissions: Significant differences in particulate emissions can be observed due to the differences in diesel fuel compared to marine HFO. For instance, Kasper et al. (2007) compared a 2-stroke low-speed marine diesel engine with a passenger diesel car and found that the total PNC emitted by the ship was higher than that of the passenger car, and that the mean particle diameter, $25-40 \mathrm{~nm}$, was smaller than the typical diesel car soot mode 70-90 nm (Maricq et al., 2002). The peak concentration for the ship and the car was around $5 \times 10^{9} \mathrm{~cm}^{-3}$ and $2 \times 10^{8} \mathrm{~cm}^{-3}$, respectively (Kasper et al., 2007). Similar results were reported by Jonsson et al. (2011), who furthermore estimated that the PNEF $\left(\mathrm{kg}^{-1}\right.$ fuel burned) was about a factor of 10 higher for ships in comparison with diesel buses without DPF, and about a factor of 60 higher compared to an older gasoline car. Also found to be higher the particle mass emission factors were about a factor of two compared to diesel buses without DPF. Due to different chemical composition and physical properties of the fuels, as well as different conditions of combustion, the observed morphological and composition structures of ship particles differ from diesel-engine soot. Based on TEM studies and EDS spectra of hot exhaust soot particles Moldovana et al. (2009) concluded that S, V and $\mathrm{Ni}$, which were detected in all types of ship-emitted particles, could be used as a tracer of the HFO combustion. However, the mass spectrum of the organic fraction of the ship particles strongly resembles that of emissions from a diesel bus (Murphy et al., 2009).

Aircraft and airports: The emission rates for particle number from aircraft vary in a relatively wide range $\left(\sim 10^{15}-10^{17} \mathrm{~kg}^{-1}\right.$ fuel burned) depending on the engine thrust level. This includes values of about a factor 10 higher compared to the emission rates for road vehicle engine nanoparticles $\left(\sim 2-11 \times 10^{15} \mathrm{~kg}^{-1}\right.$ fuel burned). Measurements at the apron of an airport show 2-3 times higher average PNCs compared to a busy traffic location. With respect to particle size distribution aircraft emissions cover a similar range as traffic emission with peak values around 20-40 nm (see Table 1).

Domestic biomass burning: A large body of literature demonstrates a typical range of PNCs $\left(\sim 10^{3}-10^{5} \mathrm{~cm}^{-3}\right)$ and PNEF $\left(\sim 10^{13}-10^{15} \mathrm{~kg}^{-1}\right.$ wood) as a consequence of domestic biomass burning under varying combustion conditions (see Table 1). These concentrations are comparable to those found near the roadsides in urban areas $\left(\sim 10^{4}\right.$ $10^{5} \mathrm{~cm}^{-3}$ ) (Kumar et al., 2010c). The case of the PNEFs is not that different. Each $\mathrm{kg}$ of fast and slow wood burning produces nearly the same number of particles as for each $\mathrm{km}$ driven by a HDV $\left(\sim 10^{15} \mathrm{veh}^{-1} \mathrm{~km}^{-1}\right)$ and $\operatorname{LDV}\left(\sim 10^{13}-10^{14} \mathrm{veh}^{-1} \mathrm{~km}^{-1}\right)$, respectively (Kumar et al., 2011a). In fact, fast wood burning produce emissions of particle numbers in a similar order as generally emitted by forest fires (see below); these both are also identical to those produced by traffic $(2.2-11) \times 10^{15} \mathrm{~kg}^{-1}$ (Kittelson et al., 2004). Measurement campaigns in several residential areas in Denmark, where woodstoves are used in the wintertime for space heating, have revealed the contribution of wood burning emissions to the ambient particle size distributions. The part of the size distribution that is attributed to the wood stoves has a maximum at 
about 40-100nm and an average PNC in the 10-700 nm size range of $0.6-1.5 \times 10^{3}$ $\mathrm{cm}^{-3}$ in peak hours up to $4 \times 10^{3} \mathrm{~cm}^{-3}$ (Glasius et al., 2008; Wåhlin et al., 2010). This corresponds to a 10-60\% increase above background levels of about $2.5-5 \times 10^{3} \mathrm{~cm}^{-3}$. Similarly Krecl et al. (2008) reported average PNCs in a Northern Swedish town during winter time of about $5 \times 10^{3} \mathrm{~cm}^{-3}$. Residential wood combustion was estimated to contribute with $44-57 \%$ to PNC with a peak in the $60-300 \mathrm{~nm}$ size range, while local traffic and long-range transport contributed with 43 and $0-13 \%$, respectively. Thus, domestic biomass burning emissions are similar to traffic emissions both in terms of PNEF ( $\mathrm{kg}^{-1}$ fuel) and can give as well similar contributions to air quality on terms of ambient PNC.

Forest fires: Pollution episodes associated with wildfire emissions have been recognised all over the world and an increasing trend of them has been observed. The PNEF estimated from the burning of biomass during forest fires can vary in the range of $(1-30) \times 10^{15} \mathrm{~kg}^{-1}$, the same order as traffic nanoparticle emission factors $(2.2-$ 11) $\times 10^{15} \mathrm{~kg}^{-1}$ (Kittelson et al., 2004), but 2-3 orders of magnitude higher than PNEFs form domestic biomass burning. However, freshly emitted forest fire particles are typically larger than traffic particles; the number size distribution is peaking at $~ 120$ nm.

MSW incineration and power plants: The PNCs produced by MSW incineration plants are generally reported similar to rural background $\left(\sim 10^{3} \mathrm{~cm}^{-3}\right)$. Emission strength of this source appears to be up to 4 orders of magnitude smaller than those generally measured at the tailpipe of road vehicles $\left(\sim 10^{7} \mathrm{~cm}^{-3}\right)$, presumably due to the high combustion temperature and efficient emission control measures used on current technology plants (see Section 7.7). Conversely, the PNC measured at laboratory, pilot or full scale power plants have been found to vary between $\sim 10^{8}$ and $10^{10} \mathrm{~cm}^{-3}$ at the inlet of flue gas treatment devices which has been reported to comes down to the range of $\sim 10^{5}-10^{8} \mathrm{~cm}^{-3}$ after the treatment. The treated PNCs can be up to an order of magnitude larger than those measured close to the tailpipe of road vehicles $\left(\sim 10^{7} \mathrm{~cm}^{-}\right.$ ${ }^{3}$ ) and a few orders of magnitude larger than those generally observed along the roadsides in urban areas $\left(\sim 10^{4} \mathrm{~cm}^{-3}\right)$. About 7.1 billion tons of coal was combusted worldwide in 2011 alone and this consumption trend is even likely to increase and emissions from road vehicles may fall in future (see Section 3). This evidence suggests that coal-fired power plants can emerge as a dominant source for nanoparticle emissions, although dispersion from elevated sources will lead to much reduced ground-level concentrations.

Cigarette smoking and cooking: Emissions from burning of a cigarette can increase the PNCs up to an order of magnitude over the indoor background levels (Table 1). Each cigarette produces on average $\sim 10^{12}$ particles, meaning that 1000 cigarettes burned will produce a total of $\sim 10^{15}$ particles which are equivalent to those produced by a $\operatorname{HDV}\left(\sim 10^{15} \mathrm{~km}^{-1}\right)$ when travelling for $1 \mathrm{~km}$. Likewise, cooking activities can raise the PNC levels up to 2 orders of magnitude over the indoor background levels, and the PNEF can broadly range between $\sim 10^{10}$ and $10^{12} \mathrm{~min}^{-1}$ (see Table 1). If we take the upper values of PNEF, about 1 minutes of cooking can produce the similar particles generated by $\sim 10$ minutes of cigarette smoking $\left(@ \sim 10^{11} \mathrm{~min}^{-1}\right.$ ) or $1 \mathrm{~m}$ travel by a HDV (@ 10 $\left.0^{12} \mathrm{~m}^{-1}\right)$. 
Secondary formation of nanoparticles: The rates at which nanoparticles are formed are usually very high during the nucleation burst and can easily dominate the ambient PNC with more than $90 \%$ during the nucleation event. Also in urban background and street locations secondary nanoparticle formation has been observed, especially on clean and sunny days, and can lead to 5-10 fold increase of PNCs (Ketzel et al., 2003; Ketzel et al., 2004). Both in particle size and timing of occurrence the secondary nanoparticle formation might be mistaken for traffic emission and the measurements at both and urban background and street levels are essential for avoiding confusion. Secondary formation might be a significant source in background or remote areas. However, since the formed nanoparticles are expected to be droplets without a solid core, it is not likely that specific health effects are related to them and hence these are not discussed separately in Section 7.

\section{Receptor modelling of source emission contributions}

Currently, there are major technical challenges in using atmospheric measurements to estimate the contributions of multiple sources to airborne nanoparticle concentrations. This is a very important issue if emissions of manufactured nanoparticles are to be detected in the ambient, non-workplace atmosphere which would be a pre-requisite for determining human exposures. The ideal would be a real-time instrument capable of determining particles across the full nanoparticle size range and determining their chemical composition from which their source might be inferred, but this is not currently available.

\subsection{Direct measurement methods}

Characterisation of airborne particles may be conducted on a single particle basis or upon time-averaged bulk particles sampled onto an air filter, or onto a substrate in a cascade impactor. The problem with time-averaged samples is that chemical analysis subsequent to collection will provide an average composition, and even if only a narrow size range is sampled, information on individual particle types is lost as it is the entire ensemble of particles which is analysed. If, however, a type of manufactured nanomaterial contained a characteristic chemical component not normally present in the background aerosol at significant concentrations (e.g. cerium in nanoparticulate fuel additives), then an analysis of that chemical component in a specific size fraction might provide a good measure of the abundance of that type of nanoparticle in the air sample. However, where chemical components have multiple sources and can be present in many different kinds of particle, bulk analysis will not be informative unless combined with a receptor model, as outlined in Section 6.2. In order to collect physical samples of such nanoparticles, there are a very limited number of instruments available. Those most commonly used are low pressure impactors such as the Berner or Dekati impactor (Fushimi et al., 2008) in which the pressure reduction leads to a modification in the Cunningham slip correction allowing collection of very small particles by impaction, or a Micro-Orifice Uniform Deposit Impactor which combines both high jet velocities and reductions in pressure to facilitate impaction. A variant on the Micro-Orifice Uniform Deposit Impactor (MOUDI), known as the nano-MOUDI as used by Lin et al. (2005), is specifically designed to fractionate particles within the nanoparticle size range. However, use of this sampler in conjunction with bulk chemical analysis is challenging because of the relatively small masses of material collected which may make differentiation from the substrate and reagent blank difficult, and the fact that semi-volatile materials are very 
poorly collected in these kinds of impactors in which the reduced pressures encourage volatilisation.

An alternative to impaction sampling is the use of a differential mobility analyser (DMA) to select a specific size of particle from the air which is then collected on a filter for subsequent chemical analysis or examination by electron microscopy. This method depends upon electrical charging of particles as they enter the instrument and selection of a specific size of charged particle based upon its mobility within an electric field in the DMA. Provided particles receive only a single electrical charge, it is only particles of a given diameter which exit the DMA and are collected. This is a very inefficient means of particle separation (due to low charging efficiencies and losses in the DMA) but has the advantage of operating at atmospheric pressure and has been used for the sampling of particles containing semi-volatile constituents (Prashintsev et al., 2011; Ruiz-Jimenez et al., 2011).

The alternative to bulk techniques is the use of single particle analysis. This breaks down further into techniques based upon electron microscopy, and real-time techniques based upon mass spectrometry. In the former case, particles collected on a filter or directly onto an electron microscope grid can be examined using a transmission electron microscope (Jefferson, 2000; Maynard, 2000) or possibly an atomic force microscope which will allow sizing resolution down to 1 nanometre or potentially even smaller sizes. In the case of the electron microscope, but not the atomic force microscope, it may be possible to collect information on the chemical constitution of individual particles from the secondary x-ray spectra. However, the smaller the particle, the less intense such spectra, and consequently it is very difficult to provide detailed characterisation of such particles in the absence of prior compositional knowledge. Another difficulty with such techniques is the laborious nature, even with automated instruments, of characterising sufficient particles to be statistically representative.

Mass spectrometric techniques are highly sensitive and may operate either at a single particle or a bulk level. The Aerosol Time-of-Flight Mass Spectrometer (ATOFMS) is an instrument which creates a beam of particles at its inlet as they are drawn in through a nozzle or focussing lens and accelerate into the reduced pressure within the instrument. Particle sizing is achieved by measuring the time of transit between two low powered lasers before the particle enters the source of the mass spectrometer where it is ablated by a high powered laser (Suess and Prather, 1999). This creates chemical fragments which are characterised in positive and negative mode reflectron ATOFMS giving both positive and negative mass spectra from the particle. The technique is highly sensitive, but commercial instruments which were available until recently have a lower cut-off of around $200 \mathrm{~nm}$ primarily because the light scattering intensities from the sizing lasers become too low at smaller particle sizes (Kane et al., 2001). However, Prather and co-workers were able to develop an instrument with greater sensitivity which characterises particles as small as $50 \mathrm{~nm}$ diameter ( $\mathrm{Su}$ et al., 2004). Nonetheless, the mass spectral measurements in the ATOFMS are subject to substantial matrix effects and there are challenges to particle characterisation arising from differential sensitivity between elements, and the fact that the laser ablation process does not ablate the entire particle and quantification is even more challenging (Dall'Osto et al., 2006). 
The Aerodyne Aerosol Mass Spectrometer (AMS) has proved extremely valuable as a continuous measurement instrument for non-refractory components of airborne particles to a lower limit of around $50 \mathrm{~nm}$ (Jayne et al., 2000). The instrument depends upon collection of an ensemble of particles on a hot impaction plate which are vaporised into the mass spectrometer source. A system chopping the incoming particle beam uses time-of-flight to achieve size separation. Size differentiation is obtained, and hence major non-refractory components are quantified as a function of particle size. Those components measured by the AMS are typically sulphate, nitrate, chloride and organic carbon. However, by application of the Positive Matrix Factorisation (PMF) programme to the mass spectra obtained, it may be possible to disaggregate the organic carbon into generic categories, typically hydrocarbon-like organic aerosol (HOA) and oxidised organic aerosol (OOA), the latter sometimes being sub-divided into low volatility and high volatility sub-categories. Using a combination of aerosol mass spectrometry and measures of particle hygroscopicity and volatility (Sakurai et al., 2005; Smith et al., 2005) has demonstrated the presence of new particles $(6-15 \mathrm{~nm})$ comprised entirely of ammonium sulphate since no other compounds were detected in these small particles. However, such observations are relatively uncommon. Evidence of the contribution of semi-volatile compounds to the condensational growth of new particles larger than $33 \mathrm{~nm}$ was also reported by Zhang et al. (2004) from measurements with an AMS. Nucleation appeared to involve sulphate and subsequently ammonia, with condensation of organics subsequently contributing primarily to particle growth.

Similar techniques, specifically the Thermal Desorption Particle Beam Mass Spectrometer (TDPBMS) have been applied to particles collected from engine emissions, sometimes in combination with a volatilisation and humidification tandem differential mobility analyser. This allows measurements of chemical composition derived from mass spectra to be viewed alongside particle physical properties (volatility; hygroscopicity) allowing inferences over particle composition. Schneider et al. (2005) demonstrated the importance of sulphate in initial nucleation of particles in diesel exhaust while other studies (Sakurai et al., 2003; Tobias et al., 2001) have shown the presence of branched alkanes and alkyl-substituted alkanes from lubricating oil and unburnt fuel making up a substantial part of the nanoparticle mass in diesel engine emissions. Using the Ultrafine Aerosol Time-of-Flight Mass Spectrometer (UF-ATOFMS) referred to above, Sodeman et al. (2005) examined emitted particles from gasoline engines in the range 50-300 nm aerodynamic diameter, finding the dominant class comprised elemental carbon internally mixed with calcium, phosphate, sulphate and a lower abundance of organic carbon.

\subsection{Source Apportionment}

There are a number of methods known as receptor modelling for source apportionment of airborne particulate matter based upon chemically-speciated ambient air quality data, see review by Viana et al. (2008). The most commonly used methods are the Chemical Mass Balance (CMB) model and the multivariate statistical models (Watson et al., 2002). The CMB model is based upon the assumption that the composition of particles measured in the atmosphere is a linear sum of the composition of the individual contributing sources weighted by their relative contributions. Such a model is difficult to apply to nanoparticles in the atmosphere as the chemical composition of each source in the relevant size fraction must be known, and such information is generally available only for $\mathrm{PM}_{2.5}, \mathrm{PM}_{10}$ and TSP size 
fractions. On the other hand, the multivariate statistical techniques require no a priori knowledge of source composition. Rather, they work by examining correlations between components in a multi-dimensional space, hence identifying those components which are associated with one another even though one element may be associated in different particle types with a number of other elements. Techniques which have been widely used include Principal Component Analysis (PCA) and PMF, both of which are variants of Factor Analysis. PMF has the advantage of weighting variables according to their analytical uncertainty, and unlike PCA, is constrained not to give negative solutions.

By far the greatest number of applications of PCA, PMF and related techniques has been to large multi-component chemical datasets of ambient measurements. As a general guideline, the number of independent samples should exceed the number of analytical variables by at least a factor of three (Pant and Harrison, 2012), and the fact that most studies involve 20 or more analytical variables requires a large number of samples in order to generate stable outcomes. While such methods have been applied in very many studies to $\mathrm{PM}_{2.5}, \mathrm{PM}_{10}$ and TSP fractions of particles, there have been few, if any applications directly to nanoparticles because of the difficulty of collecting multiple sequential samples of nanoparticles from the atmosphere. The relatively long time intervals required to sample a sufficient mass of nanoparticles makes the job of the statistical programme more difficult as time averaging will tend to smear out the impact of individual sources which might otherwise be more readily identified in the data. Pey et al. (2009) combined multi-element chemical measurements in $\mathrm{PM}_{2.5}$ and $\mathrm{PM}_{10}$ with nine particle number size bins between 13-800 $\mathrm{nm}$ in a PCA analysis. The main contribution in Barcelona to PNCs in the 13-800 nm size range were vehicle exhaust $(65 \%)$ and regional/urban background (24\%). Regional photochemically induced nucleation accounted for 3\% of PNCs in the 13-800 nm range, but $23 \%$ of $\mathrm{PNCs}$ in the 13-20 $\mathrm{nm}$ range.

A small number of studies have applied PMF or a related technique to multiple measurements of particle number size distribution. For example, Harrison et al. (2011) applied PMF to hourly particle size distribution data collected over a three week period adjacent to a busy London highway. The data were in 103 size bins from $15 \mathrm{~nm}$ to $10 \mu \mathrm{m}$ diameter and 10 separate factors were identified representing the contributions of different source types to the measured size distributions. By this means it was possible to separate and quantify the contributions of the nucleation mode of traffic exhaust centred on $20 \mathrm{~nm}$ from the solid particle mode in traffic exhaust with a mode at 50-60 nm diameter. Because of the highly dynamic nature of aerosol size distributions in urban air, factor analysis methods struggle to split out individual size distributions. Working in a street canyon situation where there are predominant sources, and inputting other traffic-related and meteorological variables makes the task more tractable (Harrison et al., 2011). Other studies which have also applied PMF to repeated measurements of particle size distributions include those of Ogulei et al. (2006a; 2006b).

In another study of vehicle emissions, Klems et al. (2011) correlated spikes in PNCs with fast changes in ultrafine particle chemical composition measured with a nanoaerosol mass spectrometer in order to determine the contribution of motor vehicles to the total ambient ultrafine particle mass. They concluded that motor vehicles contribute $48 \%$ of the ultrafine particle mass at their site during a winter measurement 
period but only $16 \%$ in the summer period. Chemical components used to identify the motor vehicle contribution were sulphate, nitrate, ammonium, low $\mathrm{O}: \mathrm{C}$ ratio organic compounds and high $\mathrm{O}: \mathrm{C}$ ratio organic compounds. These are rather non-specific measurements but by using correlations with particle number count at a roadside site, were effective in identifying the vehicular contributions.

These studies of vehicle emissions are illustrative of the techniques available, as few studies have sought to quantify NES nanoparticles. Examples are the urban studies of Alam et al. (2003) and Reche et al. (2011) in which particles formed by atmospheric nucleation were differentiated from those due to traffic by using markers of traffic emissions. Fast-response measurements of nanoparticles close to airport runways have been used to identify particles arising from jet engines (Hsu et al., 2012; Hu et al., 2009). Peak nanoparticle concentrations were elevated by a factor 440 relative to background levels during a jet departure (Hu et al., 2009), but all landing and take-off activities contributed median values of $9.8 \%$ and $6.6 \%$ of longer-term average concentrations at two sites adjacent to an airport's principal runway (Hsu et al., 2012).

\section{Exposure risks, health and regulatory implications \\ 7.1 Road-tyre interaction and re-suspension}

The mechanisms and properties that make particles from the road-tyre interaction more or less toxic are not well understood. Some metals such as $\mathrm{Fe}, \mathrm{Cu}$, $\mathrm{Pb}$, and $\mathrm{Zn}$ appear to be ubiquitous and have been repeatedly reported to display high concentrations in brake linings (Thorpe and Harrison, 2008). Around 13\% of the tyre debris material is organic, present in the various curing agents, accelerators and other additives. Some organic material (tyre polymer and extender oils) can be vaporised leading to highly carcinogenic volatile compounds such as PAHs which subsequently condense onto small particles (Aatmeeyata et al., 2009). In spite of contrasting results, the European regulation has required the discontinuation of the use of high aromatic oil containing PAH in the manufacture of tyres starting in 2010 (European Commissions, 2005). For example, Kreider et al. (2010) used the gas chromatography coupled with 2D mass spectrometry for coarse particles. They found that the total PAH content of the tread wear particles (in ppm of particle mixture) represented only $5 \%$ of the total PAH content of the road wear particles. This indicated that other sources such as natural sources, asphalt, automobile exhaust and fuel combustion products significantly contribute to the PAH content of road wear particles. Gustafsson et al. (2008) conducted cell studies on particles sampled from road simulator tests with studded tyres on two road surfaces. The results indicated that particles from studded tyre wear of pavements can induce inflammation in airways and that the type of stone material used in pavement is important for the level of this contribution. Karlsson et al. (2011) examined the toxicoproteomic effects on human monocyte derived macrophages after exposure to wear particles generated from the interface of studded tyres and a granite-containing pavement. They found that proteins associated with inflammatory response were increased and proteins involved in cellular functions were decreased.

\subsection{Construction and Demolition}

Construction and demolition activities have been found to increase particle mass concentrations in the close vicinity of building sites. This increase is likely to be for brief periods (Dorevitch et al., 2006) but may adversely affect the respiratory health of nearby residents. While there are such exposure-response relationship are available 
for the coarse and fine particles (Atkinson et al., 2010; Nauenberg and Basu, 1999), the contribution to such effects is yet to be established for nanoparticles, especially those generated from building activities. These, unlike traffic generated nanoparticles (Morawska et al., 2008), can have a substantial non-volatile fraction (Kumar et al., 2010a).

There are currently no regulations in place to control nanoparticles at building sites. Though there are individual guidelines for coarse particles, such as those recommended by the Building Research Establishment (BRE) for the UK (Kukadia et al., 2003). Control measures adopted are generally 'low-tech' like spraying of water which has been found to decrease the $\mathrm{PM}_{10}$ concentrations by up to 10 times during demolition (Kukadia et al., 2003). For nanoparticles, a Health and Safety Research Report (HSE, 2006) suggests assessment measures, but the scope of the report is limited to 'engineered nanoparticles (i.e. those produced from engineering processes)' and related exposure in workplaces (Kuhlbusch et al., 2011). Despite the notable advances in construction methods and materials used, continuously increasing awareness towards emerging air pollutants and ever increasing strictness of the Health and Safety regulations, no existing or visible plans appear to exist currently for developing risk assessment and management strategies for nanoparticles related to building activities (Kumar et al., 2012b).

A number of psychosocial hazards and exposure risks occur routinely at building sites. This require prevention through close cooperation between governments, employers and workers (Murie, 2007). Exposure to building derived nanoparticles is one such risk to site workers, passers-by and nearby residents which has not been adequately assessed to date (Kumar et al., 2012b), though a few studies exist on the exposure assessment of $\mathrm{PM}_{10}$ (Beck et al., 2003; Dorevitch et al., 2006). As discussed in Kumar et al. $(2012 b ; 2012 c)$, there is a need to determine emission rates of nanoparticle dust from a range of building activities for developing emission inventories for different situations.

\subsection{Ship emissions and seaports}

Ship emissions are one of the least regulated sources of anthropogenic emissions (Eyring et al., 2005). The International Maritime Organization (IMO) which is responsible for the international regulations of pollutants from ships has set the emission limits for NOx and SOx in the revised Marpol Annex VI rules (IMO, 1998). National or regional regulations call for even more stringent limits than those given by the IMO. For example, in June 2004, the EU environment ministers agreed a $1.5 \%$ sulphur limit for fuels used by all ships in the Baltic Sea, North Sea and English Channel, and $0.25 \%$ sulphur limit on fuel used by seagoing ships at berth in EU ports (Eyring et al., 2005). Additionally, because the Baltic Sea is an emission control area for SOx (SECA) the ships operating there must use reduced-sulphur fuels (fuel sulphur content less than or equal to $1 \%$ by weight) from 1 July 2010, and this will be decreased to $0.1 \%$ in January 2015 . The Baltic Sea is a busy area for short-sea marine traffic; about 3500-5000 different vessels are in operation every month (Jalkanen et al., 2011). Stringent limits for the sulphur content of marine fuels will also decrease PM emissions, as the major part of the PM emissions is in the form of sulphate.

No regulations regarding particles were introduced. However, the contribution from shipping $\mathrm{PM}_{10}$ emissions globally is the same order as the contribution from road 
traffic, 1.7 and $2.1 \mathrm{Tg} \mathrm{yr}^{-1}$, respectively (Eyring et al., 2005). A major part of ship emissions $(\sim 70 \%)$ occurs within $400 \mathrm{~km}$ of coastlines leading to reduced air quality in coastal areas and harbours. Isakson et al. (2001) report that in the harbour of Göteborg, exposure of PNCs smaller than $100 \mathrm{~nm}$ increased by a factor of 3 when a ship plume was recorded; however, simultaneously the mass particle size distribution was not significantly affected. Corbett et al. (2007) estimated that shipping-related $\mathrm{PM}_{2.5}$ emissions are responsible for approximately 60,000 premature cardiopulmonary and lung cancer deaths annually at a global scale. Their method was based on the ship emission inventory data sets, atmospheric transportation and chemistry models, exposure and mortality estimations. The highest mortality rates were reported near coastlines in Europe, East Asia, and South Asia surrounded by large populations. No such estimates are available for nanoparticle exposure due to the lack of the shipping nanoparticle emission data sets.

\subsection{Aircraft and airports}

Buonanno et al., (2012b) measured the PNC at two fixed locations at an aviation base and occupational personal exposure of workers at the base. Personal exposure concentrations were, as expected, higher (by factors 1.5 to 3 ) than at the fixed sites due to the lower distances experienced by the workers to the main sources. Despite the absolute exposure levels measured in this study being lower than rush-hour concentrations at busy streets, the relationship between concentrations at fixed monitoring sites and personal exposure has to been taken into account in health related assessments.

A Danish study showed that the average PNC $(6-700 \mathrm{~nm})$ was about two to three times higher at the apron of Copenhagen airport compared to a busy road in downtown Copenhagen. About $85-90 \%$ of the PNCs consisted of particles with diameter between 6 and $40 \mathrm{~nm}$. Analysis of the wind direction and time dependence could clearly show that the nanoparticles originate from combustion of jet fuel and diesel at the apron. At the outskirts of the airport the PNCs were 20-40\% lower than on a downtown street. No limit values currently exist for airborne PNCs at airports, but the high PNCs have raised concern regarding possible health effects. As a result, the airport authorities have recently presented an air quality action plan for the airport (CPH., 2011). Suggested actions are a promotion of the introduction of electrical vehicles and handling equipment, reduction of idle emissions from vehicles and APU operation times by raising awareness among pilots and airport workers. Also technical improvements are suggested that require and international efforts and coordination as particle filters on APU's and lower sulphur content in jet fuel. Moreover, the National Board of Industrial Injuries in Denmark has recognised several cancer cases most likely caused by air pollution in airports. The Copenhagen study received international attention and similar measurements have now been initiated in several European airports. The linkage from nanoparticle exposure at airports to health effects for the workers at the airport is not yet fully established due to the large number of possible co-contaminants and other influencing factors. Epidemiological studies comparing the health records of airport staff with reference groups are underway.

\subsection{Domestic biomass burning}

About 14\% and 11\% of the world's final energy consumption in 2000 and 2001, respectively, came from biomass energy (IEA, 2003). Hence the assessment of nanoparticle emissions and exposure during cooking is particularly important since 
the biomass is a primary energy source for about 2.4 billion people in developing countries (IEA, 2003) and adverse effects might be associated with the increased exposure to domestic wood smoke which are hitherto unknown (Nielsen et al., 2008). As well in the developed countries woodstoves for space heating have become more popular in recent years since fuel prices in general are increasing and wood is considered a $\mathrm{CO}_{2}$-neutral and renewable energy source. Burning of biomass produces particle number emissions that are highly variable in total number and size distributions, as well as chemical characteristics (Section 4.6). These physicochemical changes are also likely to influence the biological effects produced by wood smoke particles (Bølling et al., 2009). Review studies on the health effects of such particles indicate somewhat greater respiratory effects compared with cardiovascular effects (Naeher et al., 2007) since their exposure affects both systemic and lung biomarkers (Barregar et al., 2006; Barregard et al., 2008). Recent classification by the International Agency for Research on Cancer (IARC) for indoor emissions from household combustion of biomass fuel (mainly wood) indicated it to be probably carcinogenic (group 2A) to humans (Straif et al., 2006). However, there are yet no policy guidelines to limit exposure to wood combustion produced nanoparticles. A recent Danish study (Nielsen et al., 2008) established health effects of wood combustion-derived fine particles on mortality rates, though a similar study for nanoparticles was beyond the scope of this work.

\subsection{Forest fires}

Forest fires emit hazardous gases $\mathrm{CO}, \mathrm{NO}_{\mathrm{x}}, \mathrm{SO}_{2}, \mathrm{HC}$, and $\mathrm{PAH}$ in addition to high PNCs. Nanoparticle emissions from forest fires are beyond the regulatory control, although no such regulations currently exist even for prescribed burning. There is only a rudimentary understanding of the health effects of wildfire smoke on human health. Recent research report increased hospital attendances for asthma, respiratory symptoms, chronic obstructive pulmonary disease and chest pain during smoke-haze episodes; greater in those with pre-existing heart or lung conditions and age $>65$ years (Bowman and Johnston, 2005). During the 1997 smoke-haze episode in Indonesia, outpatient visits increased two to three fold during the main haze episode and daily respiratory disease outpatient visits more than threefold in Malaysia (Heil and Goldammer, 2001). However, most of current research focuses on health effects related to gaseous pollutants or for $\mathrm{PM}_{10}$ exposure from wildfire smokes and similar kind of exposure-response relationships are yet to be established for PNCs.

\subsection{MSW incineration}

Even the most technologically advanced incinerators release hazardous byproducts through the stack into the ambient air. Besides nanoparticles, $\mathrm{PM}_{2.5}, \mathrm{PM}_{10}$ and ash, these may also contain organic chemicals, including dioxins, heavy metals, and halogenated organic compounds. The physical and chemical nature of MSW incineration emissions is continuously changing. For instance, the growing use of nanotechnology-integrated products is likely to increase the presence of nanomaterial containing products within the municipal waste, meaning a greater likelihood of nanocomposites combustion through MSW incineration. However, the work of Buonanno et al. (2008, 2009a; 2011) and Angelucci et al. (2010) indicates that the flue gas treatment used on current technology incinerators is highly efficient, reducing nanoparticle concentrations in stack gases to levels comparable with ambient air. Consequently, the PNCs associated with MSW incineration are likely to be 
considerably smaller in quantity compared with a major source such as road traffic emissions (Dall'Osto et al., 2011; Kumar et al., 2010c).

\subsection{Power plants}

The coal used in power plants contain large amount of inorganic impurities (e.g. $\mathrm{Cr}, \mathrm{Ni}$, pyrite) that are transformed into the potentially harmful by-products such as nanoparticles at high temperatures. Lack of nanoparticle emission legislation and the limited efficiency of after treatment devices such as the ESP (Biswas and Wu, 2005) allow them to escape into the ambient environment for human inhalation. Given the potentially bioreactive nature of such transition metal-bearing nanoparticles, there is likely to be an increased health risk associated with their inhalation (Silva and da Boit, 2011). However, there are no studies currently available which have apportioned the health impacts of power plants derived nanoparticles from those arising from other sources (e.g. road vehicles). As for other sources, the only assumption considered whiles assessing their health impacts is that the particle toxicity increases with decreasing particle size and the health effects depends more on the PNCs than on their mass (Heal et al., 2012; Oberdorster et al., 2002).

\subsection{Cigarette emissions}

Cigarette smoke contains hundreds of toxic chemicals (Baker, 1980), including a notable amount of nanoparticles (Section 4.9). Active smoking is widely recognised as one of the major causes of coronary artery disease, cancer (particularly lung cancer), and chronic obstructive pulmonary disease in adults (USDHHS, 2006), as well as impacting the function of the endothelium and causing altered gene expression in endothelial cells via their ability to generate ROS and nitrogen species (Bercher et al., 2007; Mo et al., 2012). Insoluble nanoparticles are capable of translocation from the lung to other parts such as the lymph nodes, spleen, heart and bone marrow; their high surface to mass ratio increases biological activity relative to larger particles of the same chemical composition (Oberdörster et al., 2005; Kreyling et al., 2010). Recent research indicate that co-exposure to ambient nanoparticles and cigarette smoke extract causes enhanced injury to endothelial cells and may cause combined effects on activation of endothelial cells and dysfunction of the endothelium by oxidative stress through activation of NADPH oxidase (Mo et al., 2012). However, there are so far no studies available which have apportioned the effect of cigarette derived nanoparticle exposure from effects caused by other ambient nanoparticles.

On $26^{\text {th }}$ March 2006, $2^{\text {nd }}$ April 2007, 30 ${ }^{\text {th }}$ April 2007 and $1^{\text {st }}$ July 2007, a ban on smoking in all enclosed workplaces and/or public places was introduced as a consequence of the Health Act 2006 in Scotland, Wales, Northern Ireland and England, respectively. Similar bans to smoke tobacco are already in place in over 100 countries worldwide including Ireland, a few states in USA, New Zealand, Norway, Germany, and Italy to reduce passive smoke exposure to the general population. Recent studies have found notable reductions in nanoparticle exposure in public indoor places as a consequence of such bans (Valente et al., 2007). Such regulations are not directly targeted towards nanoparticle exposure but these do so indirectly as a consequence of reduced environmental tobacco smoke. However there is as yet no control on tobacco smoking in residential indoor environments and studies informing detailed physicochemical characteristics of cigarette emitted nanoparticles are needed.

\subsection{Cooking (restaurant / residential)}


Cooking fumes contain nanoparticles in large quantities and other organic and inorganic toxic contaminants and may be harmful to residential cooks, chefs, building occupants and to those visiting commercial hot food outlets (Kim et al., 2011). Past studies have shown direct relations between the exposure to gas-stove cooking fumes and respiratory ailments and lung cancer (Ko et al., 2000). During cooking the PNCs can exceed an order of magnitude over the indoor background and few times higher than outdoor concentrations and can persist for up to an hour in living rooms and an hour and a half in the kitchen (Wan et al., 2011) even after the cooking (see Section 4.10.2), indicating greater exposure levels. Furthermore, the large surface areas of nanoparticles can absorb harmful pollutants (e.g. PAH and nitrated PAHs) on their surfaces which can further enhance the risk to exposed individuals (See and Balasubramanian, 2006).

Numerous guidelines have been suggested by a number of agencies (e.g. Environmental Protection Agency, Occupational Safety and Health Administration; World Health Organisation; see complete list and details of included pollutants in Table 6 of Kim et al., 2011) worldwide to protect public health from cooking smoke; by far the main risks arises from emissions from solid fuels burned unvented in a confined space. However, health guidelines for cooking are generally limited to pollutants such as CO, BTX (Benzene, Toluene, and Xylene) and formaldehyde. Currently, there are no guidelines or regulations in place for commercial or residential cooking for nanoparticle emissions, though forming such regulations are a difficult task given the variability in emissions as discussed in Section 4.10. For accurate hazard identification, exposure assessment and risk characterization, detailed knowledge of the temporal and spatial variation of number and size distributions, and morphological and chemical characteristics, for a range of cooking activities is a need.

\section{Summary, conclusions and future research challenges}

The article comprehensively reviews the characteristics of 11 major NES to discuss their related importance against the major source of nanoparticles (i.e. road vehicles) and implications towards the exposure to public health and regulations. Future research needs and challenges are also highlighted. The formation mechanism of covered NES can be broadly divided into three categories: (i) combustion of fuel, oil and biomass, (ii) mechanical attrition during building activities or road-tyre interaction, and (iii) secondary formation in the atmosphere. While nanoparticle emissions from a few NES have been studied well, the others such as construction and demolition, road-tyre interaction, and MSW incineration appear to have extremely limited information, indicating a need for further research. The key conclusions related to the individual NES are summarised below.

- The formation mechanism of nanoparticles from road-tyre interaction is poorly understood and the reported PNEFs for road-tyre interaction vary more than an order of magnitude. More measurements are needed to find out the particle number (and mass) emission factors for direct road wear and indirect emissions due to suspension, and their dependences on many variables including vehicle speed, tyre type, road wetness, and springtime activities such as dust binding and street cleaning. This information, for example, can be utilised by the air quality models such as recently developed non-exhaust emission model 'NORTRIP' for $\mathrm{PM}_{10}$ (Berger and Denby, 2011; Johansson et al., 2012). 
- Construction and demolition activities are essential to address the need of growing world's population. While a handful of studies currently exist to draw conclusions about the extent of release of nanoparticle emissions, recent research has strengthened the view that construction and demolition processes can significantly release particles in the nanosize range (Kumar et al., 2012c), depending on factors such as construction and demolition method, meteorological conditions, structure type, and type of material demolished (Kumar et al., 2012b). The likely exposure to site workers, passers-by or the people living in the vicinity of building sites are still to be established.

- Many factors such as fuel, after-treatment system and engine load affect ship emissions which vary in the $1.3-6 \times 10^{16} \mathrm{~km}^{-1}$ range, with the PNDs peaking at about 10-20 and 50-100 $\mathrm{nm}$. More measurements are needed to study the effects of engine technology (fuel, lubricant oil, after-treatment system) on ship exhaust. Special interest concerns ships equipped with a SCR or scrubbing system. To improve the quantification of indirect effects of $\mathrm{SO}_{2}$, better estimates of particle size distributions as well as quantification and location of emissions are needed (Fuglesvedt et al., 2009).

- Airports are a significant source of nanoparticles generated by airplane engines and ground service activities both to the workers at the airport and residents in the surroundings. Several studies have shown high ambient levels of PNC, and measured PNEFs $\left(\mathrm{kg}^{-1}\right.$ fuel) are higher than comparable values for road traffic. Despite a lack of toxicological studies related to airport emissions, a likely health effect due to airport nanoparticle emissions appears possible.

- $M S W$ incineration is known to produce many chemical compounds besides nanoparticle emissions. The extent of nanoparticle release varies depending on the type of waste incinerated, as well as flue gas treatment system deployed. There is a need to investigate the release of nanoparticles as a function of the MSW incineration process and abatement plant.

- Emission factors from domestic biomass burning show a large range of variation due to the variability in burning conditions, fuels used and other less controlled parameters. There is a clear indication that both indoor and ambient exposures due to domestic biomass burning cause adverse health effects in the affected population. Experimental studies indicate that each $\mathrm{kg}$ of wood burned during a fast and slow combustion process can produce nanoparticle emissions equivalent to those emitted per km by a HDV and LDV, respectively, in typical operational conditions. Following renewable energy initiatives, use of biomass within the European Union has nearly tripled over past decades compared with the 1999 levels (Khan et al., 2009). This indicates an increasing importance of this source, which still requires due attention to understand nanoparticle emissions with more confidence.

- The properties of nanoparticles produced by forest fires vary substantially depending on the combustion phase, fuel type and moisture, wind conditions and many other variables (Reid et al., 2005). Furthermore, during dispersion a transformation of particles occurs and changes their physical, chemical and optical properties rapidly. While emission factors for grassland and savanna are relatively well known, very large uncertainty still exists in nanoparticle emission factors for boreal, temperate, and some tropical forests. Regional and 
global climate models need more accurate information. Enhanced co-ordination and networking among the smoke-haze-affected countries, including a standardisation of measurement and reporting procedures, could improve the management of forest fires (Heil and Goldammer, 2001).

- Emissions from coal power plants have been studied extensively in the past, mainly due to their association with large PM and gaseous emissions, but data on nanoparticle emissions and their size distributions is still scarce. Available research indicates substantial nanoparticle emissions (over 2 orders of magnitude larger in treated flue gas than urban background; Table 1) due to their survival from the coagulation process and after treatment systems since combustion takes place at a high temperature that promotes the metal vaporisation-nucleation pathway (Carbone et al., 2010b). The effect of enhanced oxygen on combustion conditions plays a key role in defining the quantities of nanoparticles which has yet to be studied in detail, as is the case with the effectiveness of after treatment systems ( $\mathrm{Li}$ et al., 2009). Since the collection efficiency of after treatment systems is dependent on the diffusive properties (which increase with decreased particle size) and field charging (which decreases with increased particle size), better methods for efficiently charging nanoparticles are needed for effective control.

- Cigarette smoke and cooking are the dominant sources of nanoparticles in indoor environments, and they both also act as an important point source of emissions to outdoor environments. Regardless of the types of cigarettes used, their nanoparticle emissions are consistently high, but comparable to each other, producing a peak at about $100 \mathrm{~nm}$. Conversely, most of the particles produced by cooking are below $100 \mathrm{~nm}$, with the dominant peak being below $50 \mathrm{~nm}$. Very little knowledge currently exists on the nanoparticle emissions and changes in their physicochemical characteristics after emission. Given that these are among the dominant sources of indoor nanoparticle emissions, their accurate quantification is essential for both actively and passively exposed people.

- Secondary formation is a large source of nanoparticles especially in the remote areas and rural background but can also give significant contributions in urban environments. Large efforts have been made to understand the underlying principles and precursors of particle formation but still the exact mechanism remains uncertain. Secondary nanoparticles require research on both formation and climate processes, but have less relevance for health than many other sources.

- Given that a number of nanoparticle sources, including both exhaust and nonexhaust emissions contribute to pollution of the ambient environment, samples collected from the atmosphere contain a complex mixture of nanoparticles. Analysis of chemical composition to provide unique fingerprints to allow source identification and hence the opportunity to target an individual source for developing mitigation strategies is a key goal. There have been tremendous advances in online and offline methods for chemical characterisation and source apportionment of nanoparticles (Section 6). These are though not good enough for routine applications warranting further research on the development of quantitative methods for determining the molecular composition of individual 
nanoparticles, including the development of alternative ionisation methods and improved measurement sensitivity (Bzdek et al., 2012).

- For most of the 11 NES sources the toxicity of the nanoparticles and subsequent health effects due to the exposure are largely unknown and require further work. This calls for the need to enhance understanding of their physical (e.g. size, shape, morphology), chemical (e.g. oxidative potential and toxicity) and biological (e.g. fungal spores, moulds) properties as thoroughly as those produced by vehicles in order to appreciate their potential effects on the local air quality and exposed public, and design relevant mitigation exposure measures.

Some toxicological studies have indicated that nanoparticles are considerable more toxic per unit mass than the coarser particles of the same material (Donaldson et al., 1988). Although the evidence base is as yet weak, there is accumulating evidence that nanoparticle exposure is associated with adverse health outcomes affecting particularly the cardiovascular system (Heal et al., 2012). These are still emitted unabated from most of the NES covered here and their effect on public health is yet to be established, with the associated mortality and morbidity quantified. Studies have found that every $10 \mu \mathrm{g} \mathrm{m}^{-3}$ increase in $\mathrm{PM}_{2.5}$ levels is associated with a $4 \%$ increase in deaths from all causes, a $6 \%$ increase in deaths from cardiopulmonary illness and an $8 \%$ increase in lung cancer mortality (Pope et al., 2002). Few studies have developed exposure-response relationships for nanoparticles (Atkinson et al., 2010; Stölzel et al., 2007) based on epidemiological evidence. Many more such direct exposureresponse functions are needed to reflect relationships with numerous NES. One of the major hindrances in establishing such relationships is the incomplete knowledge of the biological mechanisms through which nanoparticles affect human health. Consequently no consensus has been reached to regulate airborne nanoparticles and these are being emitted unabated from various NES, unlike those emitted from road vehicles which are controlled through Euro 5/6 emission standards in Europe. Some of the sources such as the secondary atmospheric formation are, though, directly beyond the regulatory control and reducing the emissions of precursor gases seems to be the only control strategy.

\section{Acknowledgements}

PK thanks the British Council, India, for the UKIERI grant. LP and MK thank for the support from the Nordic Council of Ministers (NMR) within the project NORTRIP (Johansson et al., 2012). Authors also thank the anonymous reviewers for their valuable time to read the manuscript and constructive comments.

\section{References}

Aatmeeyata, Kaul, D.S., Sharma, M., 2009. Traffic generated non-exhaust particulate emissions from concrete pavement: A mass and particle size study for two-wheelers and small cars. Atmospheric Environment 43, 5691-5697.

AEA, 2010. UK Emissions of Air Pollutants 1970 to 2008. Department for Environment, Food and Rural Affairs (DEFRA), http://ukair.defra.gov.uk/reports/cat07/1009030925_2008_Report_final270805.pdf (accessed 10 June 2012).

Afshari, A., Matson, U., Ekberg, L.E., 2005. Characterization of indoor sources of fine and ultrafine particles: a study conducted in a full-scale chamber. Indoor Air 15, 141-150. 
Agrawal, H., Sawant, A.A., Jansen, K., Wayne Miller, J., Cocker III, D.R., 2008a. Characterization of chemical and particulate emissions from aircraft engines. Atmospheric Environment 42, 4380-4392.

Agrawal, H., Welch, W.A., Miller, J.W., Cocker, D.R., 2008b. Emission measurements form a crude oil tankder at sea. Environmental Science \& Technology 42, 7098-7103.

Alam, A., Shi, J.P., Harrison, R.M., 2003. Observations of new particle formation in urban air. Journal of Geophysical Research 108, 4093-4107.

Andreae, M.O., Crutzen, P.J., 1997. Atmospheric aerosols: Biogeochemical sources and role in atmospheric chemistry. Science 276, 1052-1058.

Andreae, M.O., Merlet, P., 2001. Emission of trace gases and aerosols from biomass burning. Global Biochemical Cycles 15, 955-966.

Angelucci, G., Bedin, K., Tirler, W., Donega, M., 2010. Ultra-fine particles in emissions of a municipal solid waste incinerator and wood. In Proceedings Venice, 2010, Third International Symposium on Energy from Biomass and Waste. Venice, Italy, 8-11 November, 2010.

AQEG, 1999. Source apportionment of airborne particulate matter in the United Kingdom. Report of the Airborne Particles Expert Group pp. 158.

AQEG, 2005. Particulate matter in the United Kingdom, AQEG. Defra London.

Atkinson, R.W., Fuller, G.W., Anderson, H.R., Harrison, R.M., Armstrong, B., 2010. Urban ambient particle metrics and health: A time-series analysis. Epidemiology 21, 501-511.

Ault, A.P., Moore, M.J., Furutani, H., Prather, K.A., 2009. Impact of emissions from the Los Angeles part region on San Diego air quality during regional transport events. Environmental Science \& Technology 43, 3500-3506.

Baker, R.R., 1980. Mechanisms of smoke formation and delivery. Recent Advances in Tobacco Smoke 6, 184-224.

Baldauf, R., Thoma, E., Hays, M., Shores, R., Kinsey, J., Gullett, B., Kimbrough, S., J., B., 2008. Traffic and meteorological impacts on near-road air quality: Summary of methods and trends from the Raleigh near-road study Journal of the Air and Waste Management Association 58 865-878.

Barregar, L., Sällsten, G., Gustafson, P., Andersson, L., Johansson, L., Basu, S., Stigendal, L., 2006. Experimental exposure to wood-smoke particles in healthy humans: effects on markers of inflammation, coagulation, and lipid peroxidation. Inhalation Toxicology 18, 845-853.

Barregard, L., Sällsten, G., Andersson, L., Almstrand, A.C., Gustafson, P., Andersson, M., Olin, A.C., 2008. Experimental exposure to wood smoke: effects on airway inflammation and oxidative stress. Occupational Environmental Medicine 65, 319-324.

Barrett, S.R.H., Britter, R.E., Waitz, I.A., 2010. Global mortality attributable to aircraft cruise emissions. Environmental Science \& Technology 44, 7736-7742.

Beck, C.M., Geyh, A., Srinivasan, A., Breysse, P.N., Eggleston, P.A., Buckley, T.J., 2003. The impact of a building implosion on airborne particulate matter in an urban community. Journal of Air and Waste Management Association 53, 1256-1264.

Bercher, R., Bucht, A., Ovrevik, J., Hongslo, J.K., Dahlman, H.J., Samuelsen, J.T., Schwarze, P.E., 2007. Involvement of NADPH oxidase and iNOS in rodent pulmonary cytokine responses to urban air and mineral particles. Inhalation Toxicology 19, 645-655.

Berger, J., Denby, B., 2011. A generalised model for traffic induced road dust emissions. Model description and evaluation. Atmospheric Environment 45, 3692-3703.

Birmili, W., Wiedensohler, A., 2000. New particle formation in the continental boundary layer: meteorological and gas phase parameter influence. Geophysical Research Letters 27, 3325-3328.

Biswas, P., Wu, C.-Y., 2005. Nanoparticle and the environment. Journal of Air and Waste Management Association 55, 708-746.

Bølling, A.K., Pagels, J., Yttri, K.E., Barregard, L., Sallsten, G., Schwarze, P.E., Boman, C., 2009. Health effects of residential wood smoke particles: the importance of combustion 
conditions and physicochemical particle properties. Particle and Fibre Toxicology 6, 29, doi:10.1186/1743-8977-1186-1129.

Boucher, O., 1999. Influence of air traffic on cirrus occurrence. Nature 397, 30-31.

Bowman, D.M.J.S., Johnston, F.H., 2005. Wildfire smoke, fire management, and human health. EcoHealth 2, 76-80.

Bowman, D.M.J.S. et al., 2009. Fire in the earth system. Science 324, 481-484.

Buonanno, G., Ficco, G., Stabile, L., 2008. Size distribution of ultrafine particles and trends of concentration near a linear (major highway) and point source (waste incinerator). Chemical Engineering Transactions 16, 95-104.

Buonanno, G., Ficco, G., Stabile, L., 2009a. Size distribution and number concentration of particles at the stack of a municipal waste incinerator. Waste Management 29, 749-755.

Buonanno, G., Morawska, L., Stabile, L., 2009b. Particle emission factors during cooking activities. Atmospheric Environment 43, 3235-3242.

Buonanno, G., Morawska, L., Stabile, L., Viola, A., 2010. Exposure to particle number, surface area and PM concentrations in pizzerias. Atmospheric Environment 44, 39633969.

Buonanno, G., Stabile, L., Avino, P., Belluso, E., 2011. Chemical, dimensional and morphological ultrafine particle characterization from a waste-to-energy plant. Waste Management 31, 2253-2262.

Buonanno, G., Morawska, L., Stabile, L., Wang, L., Giovinco, G., 2012a. A comparison of submicrometer particle dose between Australian and Italian people. Environmental Pollution 169, 183-189.

Buonanno, G., Bernabei, M., Avino, P., Stabile, L., 2012b. Occupational exposure to airborne particles and other pollutants in an aviation base. Environmental Pollution 170, 78-87.

Bzdek, B.R., Ross Pennington, M., Johnston, M.V., 2012. Single particle chemical analysis of ambient ultrafine aerosol: A review. Journal of Aerosol Science 52, 109-120.

Carbone, F., Barone, A.C., Pagliara, R., Beretta, F., D'Anna, A., D'Alessio, A., 2008. Ultrafine particles formed by heating-up of droplets of simulated ash containing metals. Environmental Engineering Science 25, 1379-1388.

Carbone, F., Beretta, F., D'Anna, A., 2010a. Size distribution functions of ultrafine ashes from pulverized coal combustion. Combustion Science and Technology 182, 668-682.

Carbone, F., Beretta, F., D’Anna, A., 2010b. Multimodal ultrafine particles from pulverized coal combustion in a laboratory scale reactor. Combustion and Flame 157, 1290-1297.

Carpentieri, M., Kumar, P., 2011. Ground-fixed and on-board measurements of nanoparticles in the wake of a moving vehicle. Atmospheric Environment 45, 5837-5852.

Chakrabarty, R.K., Moosmüller, H., Garro, M.A., Arnott, W.P., Walker, J., Susott, R.A., Babbitt, R.E., Wold, C.E., Lincoln, E.N., Hao, W.M., 2006. Emissions from the laboratory combustion of wildland fuels: Particle morphology and size. J. Geophys. Res. 111, D07204, doi:07210.01029/02005JD00665.

Chan, Y.C., Simpson, R.W., Mctainsh, G.H., Vowles, P.D., Cohen, D.D., Bailey, G.M., 1999. Source apportionment of PM2.5 and PM10 aerosols in Brisbane (Australia) by receptor modelling. Atmospheric Environment 33, 3251-3268.

Chang, M.C.O., Chow, J.C., Watson, J.G., Hopke, P.K., Yi, S.M., England, G.C., 2004. Measurement of ultrafine particle size distributions from coal-, oil-, and gas-fired stationary combustion sources. Journal of Air \& Waste Management Association 54, 1494-1505.

Cheung, H.C., Morawska, L., Ristovski, Z.D., 2011. Observation of new particle formation in subtropical urban environment. Atmospheric Chemistry and Physics 11, 3823-3833.

Corbett, J.J., Lack, D.A., Winebrake, J.J., Harder, S., Sillberman, J.A., Gold, M., 2010. Arctic shipping emissions inventories and future scenarios. Atmospheric Chemistry and Physics 10, 9689-9704. 
Corbett, J.J., Winebrake, J.J., Green, E.H., Kasibhatla, P., Eyring, V., Lauer, A., 2007. Mortality from ship emissions: A global assessment. Environmental Science \& Technology 41, 8512-8518.

CPH., 2011. Handlingsplan til forbedring af luftkvaliteten i Københavns Lufthavn (In Danish, Action plan to improve the air quality at Copenhagen Airport). Copenhagen Airports A/S. $\quad$ http://www.projektcleanair.dk/menu/documents/Handlingsplan-luftkvalitetCPH2011.pdf (accessed 10 June 2012).

Daher, N., Saleh, R., Jaroudi, E., Sheheitli, H., Badr, T., Sepetdjian, E., Al Rashidi, M., Saliba, N., Shihadeh, A., 2010. Comparison of carcinogen, carbon monoxide, and ultrafine particle emissions from narghile waterpipe and cigarette smoking: Sidestream smoke measurements and assessment of second-hand smoke emission factors. Atmospheric Environment 44, 8-14.

Dahl, A., Gharibi, A., Swietlicki, E., Gudmundsson, A., Bohgard, M., Ljungman, A., Blomqvist, G., Gustafsson, M., 2006. Traffic-generated emissions of ultrafine particles from pavement-tire interface. Atmospheric Environment 40, 1314-1323.

Dal Maso, M., Kulmala, M., Riipinen, I., Wagner, R., Hussein, T., Aalto, P.P., Lehtinen, K.E.J., 2005. Formation and growth of fresh atmospheric aerosols: Eight years of aerosol size distribution data from SMEAR II, Hyytiälä, Finland. Boreal Environment Research $10,323-336$

Dall'Osto, M., Harrison, R.M., Beddows, D.C.S., Freney, E.J., Heal, M.R., Donovan, R.J., 2006. Single particle detection efficiencies of Aerosol Time-of-Flight Mass Spectrometry during the North Atlantic marine boundary layer experiment. Environmental Science \& Technology 40, 5029-5035.

Dall'Osto, M., Thorpe, A., Beddows, D.C.S., Harrison, R.M., Barlow, J.F., Dunbar, T., Williams, P.I., Coe, H., 2011. Remarkable dynamics of nanoparticles in the urban atmosphere. Atmospheric Chemistry and Physics 11, 6623-6637.

D'Alessio, A., Barone, A.C., Cau, R., D'Anna, A., Minutolo, P., 2005. Surface deposition and coagulation efficiency of combustion generated nanoparticles in the size range from 1 to $10 \mathrm{~nm}$. Proceedings of the Combustion Institute 30, 2595-2603.

Deacon, A.R., Derwent, R.G., Harrison, R.M., Middleton, D.R., Moorcrott, S., 1997. Analysis and interpretation of measurements of suspended particulate matter at urban background sites in the United Kingdom. Science of the Total Environment 203, 17-36.

Dennekamp, M., Howarth, S., Dick, C.A.J., Cherrie, J.W., Donaldson, K., Seaton, A., 2001. Ultrafine particles and nitrogen oxides generated by gas and electric cooking. Occupational and Environmental Medicine 58, 511-516.

Donaldson, K., Li, X.Y., MacNee, W., 1988. Ultrafine (nanometer) particle mediated lung injury. Journal of Aerosol Science 29, 553-560.

Dorevitch, S., Demirtas, H., Perksy, V.W., Erdal, S., Conroy, L., Schoonover, T., Scheff, P.A., 2006. Demolition of high-rise public housing increases particulate matter air pollution in communities of high-risk asthmatics. Journal of Air and Waste Management Association 56, 1022-1032.

EASA, 2012. Engine Exhaust Emission Database operated by the International Civil Aviation Organisation (ICAO) hosted by the European Aviation Safety Agency. Link: http://easa.europa.eu/environment/edb/aircraft-engine-emissions.php.

Ellermann, T., Massling, A., Løfstrøm, P., Winther, M., Nøjgaard, J.K., Ketzel, M., 2011. Investigation of air pollution at the apron at Copenhagen airport in relation to working environment. (Danish with English summary) DCE - Danish Centre for Environment and Energy, Aarhus University. Technical Report from DCE - Danish Centre for Environment and Energy nr. 5. http://www.dmu.dk/Pub/TR5.pdf. pp. 148.

EU, 2008. Commission Regulation (EC) No 692/2008. Official Journal of the European Union, pp 136.

European Commissions, 2005. Directive 2005/69/EC of the European Parliament and of the Council. Official Journal of the European Union. L 323/51-54. 
Eyring, V., Köhler, H.W., van Aardenne, J., Lauer, A., 2005. Emissions from international shipping: 1. The last 50 years. Journal of Geophysical Research 110, D17305, doi:17310.11029/12004JK005619.

Fiedler, V., Arnold, F., Ludmann, S., Minikin, A., Pirjola, L., Dörnbrack, A., Schlager, H., 2011. African biomass burning plumes over the Atlantic: aircraft based measurements and implications for $\mathrm{H}_{2} \mathrm{SO}_{4}$ and $\mathrm{HNO}_{3}$ mediated smoke particle activation. Atmospheric Chemistry and Physics 11, 3211-3235.

Fan, S., Wong, Y-W., Shen, L., Lu, W., Wang, T., Yu, A., Shen, Q., 2012. The effectiveness of DustBubbles on dust control in the process of concrete drilling. Safety Science 50, 1284-1289.

Fitz, D.R., Bumiller, K., Etyemezian, V., Kuhns, H., Nikolich, G., 2005. Measurement of PM10 emission rate from roadways in Las Vegas, Nevada using a SCAMPER mobile platform with real-time sensors. Presented in the14 International Emission Inventory Conference, April 12, S14, Las Vegas, Nevada.

Fraser, M.P., Yue, Z.W., Buzcu, B., 2003. Source apportionment of fine particulate matter in Houston, TX, using organic molecular markers. Atmospheric Environment 37, 21172123.

Fridell, E., Steen, E., Peterson, K., 2008. Primary particles in ship emission. Atmospheric Environment 42, 1160-1168.

Fuglesvedt, J., Berntsen, T., Eyring, V., Isaksen, I., Lee, D.S., Sausen, R., 2009. Shipping emissions: From cooling to warming of climate - and reducing impacts on health. Environmental Science \& Technology 43, 9057-9062.

Fuller, G.W., Green, D., 2004. The impact of local fugitive PM10 from building works and road works on the assessment of the European Union Limit Value. Atmospheric Environment 38, 4993-5002.

Fushimi, A., Hasegawa, S., Takahashi, K., Fujitani, Y., Tanabe, K., Kobayashi, S., 2008. Atmospheric fate of nuclei-mode particles estimated from the number concentrations and chemical composition of particles measured at roadside and background sites. Atmospheric Environment 42, 949-959.

Garg, B.D., Cadle, S.H., Mulawa, P.A., Groblicki, P.J., Laroo, C., Parr, G.A., 2000. Brake wear particulate matter emissions. Environmental Science \& Technology 34, 4463-4469.

Géhina, E., Ramalhob, O., Kirchnerb, S., 2008. Sizedistribution and emissionrate measurement of fine and ultrafine particle from indoor human activities. Atmospheric Environment 42, 8341-8352.

Glasius, M., Ketzel, M., Wåhlin, P., Bossi, R., Stubkjær, J., Hertel, O., Palmgren, F., 2008. Characterization of particles from residential wood combustion and modelling of spatial variation in a low-strength emission area. Atmospheric Environment 42, 8686-8697.

Guofeng, S., Siye, W., Wen, W., Yanyan, Z., Yujia, M., Bin, W., Rong, W., Wei, L., Huizhong, S., Ye, H., Yifeng, Y., Wei, W., Xilong, W., Xuejun, W., Shu, T., 2012. Emission factors, size distributions, and emission inventories of carbonaceous particulate matter from residential wood combustion in rural China. Environmental Science \& Technology 46, 4207-4214.

Gustafsson, M., Blomqvist, G., Gudmundsson, A., Dahl, A., Swietlicki, E., Bohgard, M., Lindbom, J., Ljungman, A., 2008. Properties and toxicological effects of particles from the interaction between tyres, road pavement and winter traction material. Science of the Total Environment 393, 226-240.

Guyon, P., Frank, G.P., Welling, M.N., Chand, D., Artaxo, P., Rizzo, L., Nishioka, G., Kolle, O., Fritsch, H., Silva Dias, M.A.F., L. V. Gatti, L.V., Cordova, A.M., Andreae, M.O., 2005. Airborne measurements of trace gas and aerosol particle emissions from biomass burning in Amazonia. Atmospheric Chemistry and Physics 5, 2989-3002.

Hansen, D., Blahout, B., Benner, D., Popp, W., 2008. Environmental sampling of particulate matter and fungal spores during demolition of a building on a hospital area. Journal of Hospital Infection 70, 259-264. 
Harrison, R.M., ApSimon, H., Clarke, A.G., Dewent, R.G., Fisher, B., Hickman, J., Mark, D., Murrells, T., McAughey, J., Pooley, F., Richards, R., Stedman, J., Vawda, Y., Williams, M., Coster, S., Mayland, R., Prosser, H., Hall, I., McMohan, N., 1999. Source apportionement of airborne particulate matter in the United Kingdom. Technical Report, Department of Environment, Transport \& the Regions, the Welsh Office, the Scottish Office \& the Department of the Environment (North Ireland).

Harrison, R.M., Beddows, D.C.S., Dall'Osto, M., 2011. PMF analysis of wide-range particle size spectra collected on a major highway. Environmental Science and Technology 45, 5522-5528.

Harrison, R.M., Hester, R.E., 1994. Waste Incineration and the Environment. RSC Publications ISBN: 978-0-85404-205-0

Hays, M.D., Fine, P.M., Geron, C.D., Kleeman, M.J., Gullett, B.K., 2005. Open burning of agricultural biomass: Physical and chemical properties of particle-phase emissions. Atmospheric Environment 39, 6747-6764.

He, C., Morawska, L., Hitchins, J., Gilbert, D., 2004. Contribution from indoor sources to particle number and mass concentrations in residential houses. Atmospheric Environment 38, 3405-3415.

Heal, M.R., Kumar, P., Harrison, R.M., 2012. Particles, air quality, policy and health. Chemical Society Reviews 41, 6606-6630.

Healy, R.M., O'Connor, I.P., Hellebust, S., Allanic, A., Sodeau, J.R., Wenger, J.C., 2009. Characterisation of single particles from in-port ship emissions. Atmospheric Environment 43, 6408-6414.

Hedberg, E., Kristensson, A., Ohlsson, M., Johansson, C., Johansson, P.-Å., Swietlicki, E., Vesely, V., Wideqvist, U., Westerholm, R., 2002. Chemical and physical characterization of emissions from birch wood combustion in a wood stove. Atmospheric Environment 36, 4823-4837.

Heil, A., Goldammer, J.G., 2001. Snoke-haze pollution: a review of the 1997 episode in Souteast Asia. Regional Environmental Change 2, 24-37.

Herndon, S.C., Jayne, J.T., Lobo, P., Onasch, T.B., Fleming, G., Hagen, D.E., Whitefield, P.D., Miake-Lye, R.C., 2008. Commercial aircraft engine emissions characterization of in-use aircraft at Hartsfield-Jackson Atlanta International Airport. Environmental Science \& Technology 42, 1877-1883.

Herndon, S.C., Onasch, T.B., Frank, B.P., Marr, L.C., Jayne, J.T., Canagaratna, M.R., Grygas, J., Lanni, T., Anderson, B.E., Worsnop, D., Miake-Lye, R.C., 2005. Particulate emissions from in-use commercial aircraft. Aerosol Science and Technology 39, 799809.

Hinds, W.C., 1999. Aerosol technology: Properties, behaviour and measurement of airborne particles. John Wiley \& Sons, UK, pp. 483.

Hodzic, A., Madronich, S., Bohn, B., Massie, S., Menut, L., Wiedinmyer, C., 2007. Wildfire particulate matter in Europe during summer 2003: meso-scale modeling,of smoke emissions, transport and radiative effects. Atmospheric Chemistry and Physics 7, 40434046.

Holmes, N., 2007. A review of particle formation events and growth in the atmosphere in the various environments and discussion of mechanistic implications. Atmospheric Environment 41, 2183-2201.

Hosseini, S., Li, Q., Cocker, D., Weise, D., Miller, A., Shrivastava, M., Miller, J.W., Mahalingam, S., Princevac, M., Jung, H., 2010. Particle size distributions from laboratory-scale biomass fires using fast response instruments. Atmospheric Chemistry and Physics 10, 8065-8076.

Hsu, H.-H., Adamkiewicz, G., Houseman, A., Vallarino, J., Melly, S.J., Wayson, R.L., Spengler, J.D., Levy, J.I., 2012. The relationship between aviation activities and ultrafine particulate matter concentrations near a mid-sized airport. Atmospheric Environment 50, 328-337. 
Hu, S., Fruin, S., Kozawa, K., Mara, S., Winer, A.M., Paulson, S.E., 2009. Aircraft emission impacts in a neighborhood adjacent to a general aviation airport in Southern California. Environmental Science and Technology 43, 8039-8045.

Hueglin, C., Gaegauf, C., Künzel, S., Burtscher, H., 1997. Characterization of wood combustion particles: morphology, mobility, and photoelectric activity. Environmental Science \& Technology 31, 3439-3447.

Hussein, T., Glytsos, T., Ondráček, J., Dohányosová, P., Ždímal, V., Hämeri, K., Lazaridis, M., Smolík, J., Kulmala, M., 2006. Particle size characterization and emission rates during indoor activities in a house. Atmospheric Environment 40, 4285-4307.

Hussein, T., Johansson, C., Karlsson, H., Hansson, H.-C., 2008. Factors affecting non-tailpipe aerosol particle emissions from paved roads: On-road measurements in Stockholm, Sweden. Atmospheric Environment 42, 688-702.

IARC, 2012. International Agency for Research on Cancer (IARC) Monographs on the Evaluation of Carcinogenic Risks to Humans, Volume 105: Diesel and gasoline engine exhausts and some nitroarenes Lyon, France, 5-12 June 2012.

IEA, 2003. International Energy Agency: Energy Balances of non-OECD countries 20002001. IEA, Paris.

Iijama, A., Sato, K., Yano, K., Tago, H., Kato, M., Kimura, H., Furuta, N., 2007. Particle size and composition distribution analysis of automotive brake abrasion dusts for the evaluation of antimony sources of airborne particulate matter. Atmospheric Environment 41, 4908-4919.

IMO, 1998. International Maritime Organization: Regulations for the prevention of air pollution from ships and NOx technical code. Annex VI of the MARPOL convention 73/78 London, 1998.

IPCC., 1999. Ed. Aviation and the Global Atmosphere; Cambridge University Press: Cambridge, U.K.

Isakson, J., Persson, T.A., Lindgren, E.S., 2001. Identification and assessment of ship emissions and their effects in the harbour of Göteborg, Sweden. Atmospheric Environment 35, 3659-3666.

Jalkanen, J.-P., Johansson, L., Kukkonen, J., Brink, A., Kalli, J., Stipa, T., 2011. Extension of an assessment model of ship traffic exhaust emissions for particulate matter and carbonmonoxide. Atmospheric Chemistry and Physics Discussion 11, 22129-22172.

Janhäll, S., Andreae, M.O., Pöschl, U., 2010. Biomass burning aerosol emissions from vegetation fires: particle number and mass emission factors and size distributions. Atmospheric Chemistry and Physics 10, 1427-1439.

Jayne, J.T., Leard, D.C., Zhang, X., Davidovits, P., Smith, K.A., Kolb, C.E., Worsnop, D.R., 2000. Development of an aerosol mass spectrometer for size and composition analysis of submicron particles. Aerosol Science and Technology 33, 49-70.

Jefferson, D.A., 2000. The surface activity of ultrafine particles. Philosophical Transactions of the Royal Society of London, Series A 358, 2683-2692.

Johansson, C., Denby, B.R., I. Sundvor, I., Kauhaniemi, M., Härkönen, J., Kukkonen, J., Karppinen, A., Kangas, L., Omstedt, G., Ketzel, M., Massling, A., Pirjola, L., Norman, M., Gustafsson, M., Blomqvist, G., Bennet, C., Kupiainen, K., Karvosenoja, N., 2012. NOn-exhaust Road TRaffic Induced Particle (NORTRIP) emissions - Development of a model for assessing the effect on air quality and exposure. ITM-report 212, Stockholm University, June 2012.

Johansson, C., Norman, M., Gidhagen, L., 2007. Spatial \& temporal variaitons of PM10 and particle number concentrations in urban air. Environmental Monitoring and Assessment $127,477-487$.

Jones, A.M., Harrison, R.M., Barratt, B., Fuller, G., 2012. A large reduction in airborne particle number concentrations at the time of the introduction of "sulphur free" diesel and the London Low Emission Zone. Atmospheric Environment 50, 129-138. 
Jonsson, Å.M., Westerlund, J., Hallquist, M., 2011. Size-resolved particle emission factors for individual ships. Geophysical Research Letters 38, L13809, doi:13810.11029/12011GL047672.

Kane, D.B., Oktem, B., Johnston, M.V., 2001. Nanoparticle detection by aerosol mass spectrometry. Aerosol Science and Technology 34, 520-527.

Karlsson, H., Lindbom, J., Ghafouri, B., Lindahl, M., Tagesson, C., Gustafsson, M., Ljungman, A.G., 2011. Wear particles from studded tires and granite pavement induce proinflammatory alterations in human monocyte-derived macrophages: a proteomic study. Chemical Research in Toxicology 24, 45-53.

Kasper, A., Aufdenblatten, S., Forss, A., Mohr, M., Burtscher, H., 2007. Particulate emissions from a low-speed marine diesel engine. Aerosol Science and Technology 41, 24-32.

Ketzel, M., Wahlin, P., Berkowicz, R., Palmgren, F., 2003. Particle and trace gas emission factors under urban driving conditions in Copenhagen based on street and roof-level observations. Atmospheric Environment 37, 2735-2749.

Ketzel, M., Wahlin, P., Kristensson, A., Swietlicki, E., Berkowicz, R., Nielsen, O.J., Palmgren, F., 2004. Particle size distribution and particle mass measurements at urban, near-city and rural level in the Copenhagen area and Southern Sweden. Atmospheric Chemistry and Physics 4, 281-292.

Khan, A.A., de Jong, W., Jansens, P.J., Spliethoff, H., 2009. Biomass combustion in fluidized bed boilers: Potential problems and remedies. Fuel Processing Technology 91, 21-50.

Khettabi, R., Songmene, V., Zaghbani, I., Masounave, J., 2010. Modeling of particle emission during dry orthogonal cutting. Journal of Materials Engineering and Performance 19, 776-789.

Kim, K.-H., Pandey, S.K., Kabir, E., Susaya, J., Brown, R.J.C., 2011. The modern paradox of unregulated cooking activities and indoor air quality. Journal of Hazardous materials $195,1-10$.

Kinsey, J.S., Dong, Y., Williams, D.C., Logan, R., 2010. Physical characterization of the fine particle emissions from commercial aircraft engines during the Aircraft Particle Emissions eXperiment (APEX) 1 to 3. Atmospheric Environment 44, 2147-2156.

Kittelson, D.B., Watts, W.F., Johnson, J.P., 2004. Nanoparticle emissions on Minnesota highways. Atmospheric Environment 38, 9-19.

Kleeman, M.J., Schauer, J.J., Cass, G.R., 1999. Size and composition distribution of fine particulate matter emitted from wood burning, meat charbroiling, and cigarettes. Environmental Science \& Technology 33, 3516-3523.

Klems, J.P., Pennington, M.R., Zordan, C.A., McFadden, L., Johnston, M.V., 2011. Apportionment of motor vehicle emissions from fast changes in number concentration and chemical composition of ultrafine particles near a roadway intersection. Environmental Science \& Technology 45, 5637-5643.

Klepeis, N.E., Apte, M.G., Gundel, L.A., Sextro, R.G., Nazaroff, W.W., 2003. Determining size-specific emission factors for environmental tobacco smoke particles. Aerosol Science and Technology 37, 780-790.

Ko, Y.C., Cheng, L.S., Lee, C.H., Huang, J.J., Huang, M.S., Kao, E.L., Wang, H.Z., Lin, H.J., 2000. Chinese food cooking and lung cancer in women nonsmokers. American Journal of Epidemiology 151, 140-147.

Knibbs, L., He, C., Duchaine, C., Morawska, L., 2012. Vacuum cleaner emissions as a source of indoor exposure to airborne particles and bacteria. Environmental Science \& Technology 46, 534-542.

Knibbs, L.D., Cole-Hunter, T., Morawska, L., 2011. A review of commuter exposure to ultrafine particles and its health effects. Atmospheric Environment 45, 2611-2622.

Krecl, P., Hedberg Larsson, E., Ström, J., Johansson, C., 2008. Contribution of residential wood combustion and other sources to hourly winter aerosol in Northern Sweden determined by positive matrix factorization. Atmospheric Chemistry and Physics 8, 3639-3653 
Kreider, M.L., Panko, J.M., McAtee, B.L., Sweet, L.I., Finley, B.L., 2010. Physical and chemical characterization of tire-related particles: Comparison of particles generated using different methodologies. Science of the Total Environment 408, 652-659.

Kreyling, W.G., Hirn, S., Schleh, C., 2010. Nanoparticles in the lung. Nature Biotechnology 28, 1275-1276.

Kristensson, A., Dal Maso, M., Swietlicki, E., Hussein, T., Zhou, J., Kerminen, V.M., Kulmala, M., 2008. Characterization of new particle formation events at a background site in Southern Sweden: relation to air mass history. Tellus B 60, 330-344.

Kuhlbusch, T., Asbach, C., Fissan, H., Gohler, D., Stintz, M., 2011. Nanoparticle exposure at nanotechnology workplaces: A review. Particle and Fibre Toxicology 8, 22.

Kuhns, H., Etyemezian, V., Landwehr, D., MacDougall, C., Pitchford, M., Green, M., 2001. Testing re-entrained aerosol kinetic emissions from roads (TRAKER): a new approach to infer silt loading on roadways. Atmospheric Environment 35, 2815-2825.

Kukadia, V., Upton, S., Grimwood, C., 2003. Contorlling particles, vapour and noise pollution from construction sites; Part 2: Site Preparation, demolition, earthworks and landscaping. BRE Pollution Guide, 1-8.

Kulmala, M., Petäjä, T., Mönkkönen, P., Koponen, I.K., Dal Maso, M., Aalto, P.P., Lehtinen, K.E.J., Kerminen, V.M., 2005. On the growth nucleation mode particles: Source rates of condensable vapor in polluted and clean environments. Atmospheric Chemistry and Physics 5, 409-416.

Kulmala, M., Vehkamaki, H., Petaja, T., Dal Maso, M., Lauri, A., Kerminen, V.-M., Birmili, W., McMurry, P.H., 2004. Formation and growth rates of ultrafine atmospheric particles: a review of observations. Journal of Aerosol Science 35, 143-176.

Kumala, M., Asmi, A., Lappalainen, H. K., Baltensperger, U., Brenguier, J.-L., Facchini, M. C., Hansson H.-C., et al., 2011. General overview: General overview: European Integrated project on Aerosol Cloud Climate and Air Quality interactions (EUCAARI) - integrating aerosol research from nano to global scales. Atmospheric Chemistry and Physics 11, 13061-13143.

Kumar, P., Fennell, P., Symonds, J., Britter, R., 2008. Treatment of losses of ultrafine aerosol particles in long sampling tubes during ambient measurements. Atmospheric Environment 42, 8819-8826.

Kumar, P., Fennell, P., Robins, A., 2010a. Comparison of the behaviour of manufactured and other airborne nanoparticles and the consequences for prioritising research and regulation activities. Journal of Nanoparticle Research 12, 1523-1530.

Kumar, P., Robins, A., ApSimon, H., 2010b. Nanoparticle emissions from biofuelled vehicles - their characteristics and impact on the number-based regulation of atmospheric particles. Atmospheric Science Letters 11, 327-331.

Kumar, P., Robins, A., Vardoulakis, S., Britter, R., 2010c. A review of the characteristics of nanoparticles in the urban atmosphere and the prospects for developing regulatory controls. Atmospheric Environment 44, 5035-5052.

Kumar, P., Ketzel, M., Vardoulakis, S., Pirjola, L., Britter, R., 2011a. Dynamics and dispersion modelling of nanoparticles from road traffic in the urban atmospheric environment - a review. Journal of Aerosol Science 42, 580-603.

Kumar, P., Robins, A., Vardoulakis, S., Quincey, P., 2011b. Technical challenges in tackling regulatory concerns for urban atmospheric nanoparticles. Particuology 9, 566-571.

Kumar, P., Morawska, L., Harrison, R.M., 2012a. Nanoparticles in European cities and associated health impacts. In: The Handbook of Environmental Chemistry (SpringerVerlag Berlin Heidelberg; Volume editor: Viana, M.) DOI: 10.1007/698_2012_161, pp. $1-27$.

Kumar, P., Mulheron, M., Fisher, B., Harrison, R.M., 2012b. New Directions: Airborne ultrafine particle dust from building activities - a source in need of quantification. Atmospheric Environment 56, 262-264. 
Kumar, P., Mulheron, M., Som, C., 2012c. Release of ultrafine particles from three simulated building processes. Journal of Nanoparticle Research 14, 771, DOI 10.1007/s11051-0120771-2.

Kupiainen, K., Pirjola, L., 2011. Vehicle non-exhaust emissions from the tyre-road interface Effect of stud properties and traction sanding. Atmospheric Environment 45, 4141-4146.

Kupiainen, K., Tervahattu, H., Raisanen, M., Makela, T., Aurela, M., Hillamo, R., 2005. Size and composition of airborne particles from pavement wear, tyres, and traction sanding. Environmental Science and Technology 39, 699-706.

Kurniawan, J.S., Khardi, S., 2011. Comparison of methodologies estimating emissions of aircraft pollutants, environmental impact assessment around airports. Environmental Impact Assessment Review 31, 240-252.

Lack, D.A., Corbett, J.J., Onasch, T., Lerner, B., Massoli, P., Quinn, P.K., Bates, T.S., Covert, D.S., Coffman, D., Sierau, B., Herndon, S., Allan, J., Baynard, T., Lovejoy, E.A., 2009. Particulate emission from commercial shipping: Chemical, physical and optical properties. Journal of Geophysical Research 114, D00F04, doi: 10.1029/2008JD011306.

Lee, S., Ghim, Y.S., Kim, S.-W., Yoon, S.-C., 2010. Effect of biomass burning and regional background aerosols on $\mathrm{CCN}$ activity derived from airborne in-situ measurements. Atmospheric Environment 44, 5227-5236.

Lee, S.C., Li, W.M., Chan, L.Y., 2001. Indoor air quality at restaurants with different styles of cooking in metropolitan Hong Kong. Science of the Total Environment 279, 181-193.

Lee, Y., Lee, H., Kim, M., Choi, C.Y., Kim, J., 2008. Characteristics of particle formation events in the coastal region of Korea in 2005. Atmospheric Environment, 3729-3739.

Lee, M-H., McClellan, W.J., Candela, J., Andrews, D., Biswas, P., 2007. Reduction of nanoparticle exposure to welding aerosols by modification of the ventilation system in a workplace. Journal of Nanoparticle Research 9, 127-136.

Li, C.S., Lin, W.H., Jenq, F.T., 1993. Size distributions of submicrometer aerosols from cooking. Environmental International 19, 147-154.

Li, Y., Suriyawong, A., Daukoru, M., Zhuang, Y., Biswas, P., 2009. Measurement and capture of fine and ultrafine particles from a pilot-scale pulverized coal combustor with an electrostatic precipitator. Journal of Air and Waste Management Association 59, 553559.

Lin, C.-C., Chen, S.-J., Juang, K.-L., 2005. Characteristics of metals in nano-ultrafine/fine/ coarse particles collected beside a heavily trafficked road. Environmental Science \& Technology 39, 8113-8122.

Linak, W.P., Wendt, J.O.L., 1993. Toxic metal emissions from incineration: Mechanisms and control. Progress in Energy and Combustion Science 19, 145-185.

Lipsky, E.M., Robinson, A.L., 2006. Effects of dilution on fine particle mass and partitioning of semivolatile organics in diesel exhaust and wood smoke. Environmental Science \& Technology 40, 155-162.

Luhana, L., Sokhi, R., Warner, L., Mao, H., Boulter, P., McCrae, I.S., 2004. Measurement of non-exhaust particulate matter. Characterisation of exhaust particulate emissions from road vehicles (PARTICULATES). Deliverable 8 of the European Commission DG TrEn 5th Framework PARTICULATES project.

Lyyränen, J., Jokiniemi, J., Kauppinen, E.I., Joutsensaari, J., 1999. Aerosol characterisation in medium-speed diesel engines operating with heavy fuel oils. Journal of Aerosol Science 30, 771-784.

Maghun, J., Karg, E., Kettrup, A., Zimmermann, R., 2003. On-line analysis of the size distribution of fine and ultrafine aerosol particles in flue and stack gas of a municipal waste incineration plant: effect of dynamic process control measures and emission reduction devices. Environmental Science and Technology 37, 4761-4770.

Maricq, M.M., Chase, R.E., Xu, N., Laing, P.M., 2002. The effects of the catalytic converter and fuel sulphur level on moteo vehicle particulate matter emissons: light duty diesel vehicle. Environmental Science \& Technology 36, 283-289. 
Maruf Hossain, A.M.M., Park, S., Kim, J.-S., Park, K., 2012. Volatility and mixing states of ultrafine particles from biomass burning. Journal of Hazardous materials 205-206, 189197.

Mathissen, M., Scheer, V., Vogt, R., Benter, T., 2011. Investigation on the potential generation of ultrafine particles from the tire-road interface. Atmospheric Environment In Press, doi: 10.1016/j.atmosenv.2011.1008.1032.

Maynard, A.D., 2000. Overview of methods for analysing single ultrafine particles. Philosophical Transactions of the Royal Society of London, Series A 358, 2593-2609.

Mazaheri, M., Johnson, G.R., Morawska, L., 2009. Particle and gaseous emissions from commercial aircraft at each stage of the landing and takeoff cycle. Environmental Science \& Technology 43, 441-446.

Mazaheri, M., Johnson, G.R., Morawska, L., 2011. An inventory of particle and gaseous emissions from large aircraft thrust engine operations at an airport. Atmospheric Environment 45, 3500-3507.

McGarry, P., Morawska, L., He, C., Jayaratne, R., Falk, M., Tran, Q., Wang, H., 2011. Exposure to particles from laser printers operating within office workplaces. Environmental Science \& Technology 45, 6444-6452.

Mo, Y., Wan, R., Feng, L., Chien, S., Tollerud, D.J., Zhang, Q., 2012. Combination effects of cigarette smoke extract and ambient ultrafine particles on endothelial cells. Toxicology in Vitro 26, 295-303.

Modini, R.L., Ristovski, Z.D., Johnson, G.R., He, C., Surawski, N., Morawska, L., Suni, T., Kulmala, M., 2009. New particle formation and growth at a remote, sub-tropical coastal location. Atmospheric Chemistry and Physics 9, 7607-7621.

Moldanova, J., Fridell, E., Popovicheva, O., Demirdjian, B., Tishkova, V., Faccinetto, A., Focsa, C., 2009. Characterisation of particulate matter and gaseous emissions from a large ship diesel engine. Atmospheric Environment 43, 2632-2641.

Morawska, L., He, C., Hitchins, J., Mengersen, K., Gilbert, D., 2003. Characteristic of particle number and mass concentrations in residential houses in Brisbane, Australia. Atmospheric Environment 37, 4195-4203.

Morawska, L., Jamriska, M., Bofingerb, N.D., 1997. Size characteristics and ageing of the environmental tobacco smoke. Science of the Total Environment 196, 43-55.

Morawska, L., Jayaratne, E.R., Knibbs, L.D., Megatmokhtar, M., 2010. Regulations and policy measures related to the reduction of ambient particulate matter. In Urban Particulate Matter: Origins, Chemistry, Fate and Health Impacts (Zereini, F. and Wiseman, C. Eds.) Springer, Berlin, Germany.

Morawska, L., Ristovski, Z., Jayaratne, E.R., Keogh, D.U., Ling, X., 2008. Ambient nano and ultrafine particles from motor vehicle emissions: Characteristics, ambient processing and implications on human exposure. Atmospheric Environment 42, 8113-8138.

Murie, F., 2007. Building safety - An international perspective. International Journal of Occupation and Environmental Health 13, 5-11.

Murphy, S.M., Agrawal, H., Sorooshian, A., Padró, L.T., Gates, H., Hersey, S., Welch, W.A., Jung, H., Miller, J.W., Cocker, D.R., Nenes, A., Jonsson, H.H., Flagan, R.C., Seinfeld, J.H., 2009. Comprehensive simultaneous shipboard and airborne characterization of exhaust from a modern container ship at sea. Environmental Science \& Technology 43, 4626-4640.

Naeher, L.P., Brauer, M., Lipsett, M., Zelikoff, J.T., Simpson, C.D., Koenig, J.Q., Smith, K.R., 2007. Woodsmoke health effects: a review. Inhalation Toxicology 19, 67-106.

Nauenberg, E., Basu, K., 1999. Effect of insurance coverage on the relationship between asthma hospitalizations and exposure to air pollution. Public Health Reports 114, 135148.

Nazari, A., Riahi, S., 2011. Splitting tensile strength of concrete using ground granulated blast furnace slag and $\mathrm{SiO} 2$ nanoparticles as binder. Energy and Buildings 43, 864-872. 
Nielsen, E., Dybdahl, M., Larsen, P.B., 2008. Health effects assessment of exposure to particles from wood smoke. Danish Ministry of The Environment, Environmental Protection Agency Environmental Project No. 1235, pp. 110.

Northcross, A.L., Hammond, S.K., Canuz, E., R., S.K., 2012. Dioxin inhalation doses from wood combustion in indoor cookfires. Atmospheric Environment 49, 415-418.

O'Dowd, C., Jimenez, J.L., Bahreinl, R., Flagan, R.C., Seinfeld, J.H., Hamerl, D., Pirjola, L., Kulmala, M., Jennings, S.G., Hoffmann, T., 2002. Marine aerosol formation from biogenic iodine emissions. Nature 417, 632.

Oberdörster, G., Oberdörster, E., Oberdörster, J., 2005. Nanotoxicology: an emerging discipline evolving from studies of ultrafine particles. Environmental Health Perspectives 113, 823-839.

Oberdorster, G., Sharp, Z., Atudorei, V., Elder, A., Gelein, R., A., L., Kreyling, W., Cox, C., 2002. Extrapulmonary translocation of ultrafine carbon particles following whole-body inhalation exposure of rats. Journal of Toxicology and Environmental Health, Part A 65, 1531-1543.

Ogulei, D., Hopke, P.K., Wallace, L.A., 2006a. Analysis of indoor particle size distribution in an occupied townhouse using positive matrix factorization. Indoor Air, 204-215.

Ogulei, D., Hopke, P.K., Zhou, L., Pancras, J.P., Nair, N., Ondov, J.M., 2006b. Source apportionment of Baltimore aerosol from combined size distribution and chemical composition data. Atmospheric Environment 40, S396-S410.

Pant, P., Harrison, R.M., 2012. Critical review of receptor modelling for particulate matter: A case study of India. Atmospheric Environment 49, 1-12.

Petters, M.D., Carrico, C.M., Kreidenweis, S.M., A.J. Prenni, A.J., DeMott, P.J., Collett, J.L., Moosmüller, J.H., 2009. Cloud condensation nucleation activity of biomass burning aerosol. Journal of Geophysical Research 114, D22205.

Petzold, A., Hasselbach, J., Lauer, P., Baumann, R., Franke, K., Gurk, C., Schlager, H., Weingartner, E., 2008. Experimental studies on particle emissions from cruising ship, their characteristic properties, transformation and atmospheric lifetime in the marine boundary layer. Atmospheric Chemistry and Physics 8, 2387-2403.

Petzold, A., Stein, C., Nyeki, S., Gysel, M., Weingartner, E., Baltensperger, U., Giebl, H., Hitzenberger, R., Döpelheuer, A., Vrchoticky, S., Puxbaum, H., Johnson, M., Hurley, C.D., Marsh, R., Wilson, C.W., 2003. Properties of jet engine combustion particles during the PartEmis experiment: Microphysics and Chemistry. Geophysical Research Letters 30, 1719.

Petzold, A., Ström, J., Schröder, F.P., Kärcher, B., 1999. Carbonaceous aerosol in jet engine exhaust: emission characteristics and implications for heterogeneous chemical reactions. Atmospheric Environment 33, 2689-2698.

Petzold, A., Weinzierl, B., Huntrieser, H., Stohl, A., Real, E., Cozic, J., Fiebig, M., Hendricks, J., Lauer, A., Law, K., Roiger, A., Schlager, H., Weingartner, E., 2007. Perturbation of the European free troposphere aerosol by North American forest fire plumes during the ICARTT-ITOP experiment in summer 2004. Atmospheric Chemistry and Physics 7, 5105-5127.

Pey, J., Querol, X., Alastuey, A., Rodríguez, S., Putaud, J.P., Van Dingenen, R., 2009. Source apportionment of urban fine and ultra fine particle number concentration in a Western Mediterranean city. Atmospheric Environment 43, 4407-4415.

Pirjola, L., Kupiainen, K.J., Perhoniemi, P., Tervahattu, H., Vesala, H., 2009. Non-exhaust emission measurement system of the mobile laboratory SNIFFER. Atmospheric Environment 43, 4703-4713.

Pope, C.A., Burnett, R.T., Thun, M.J., Calle, E.E., Krewski, D., Ito, K., Thurston, G.D., 2002. Lung cancer, cardiopulmonary mortality, and long-term exposure to fine particulate air pollution. Journal of the American Medical Association 287, 1132-1141.

Prashintsev, J., Ruiz-Jimenez, T., Petaja, T., Hartonen, K., Kulmala, M., Riekkola, M.-L., 2011. Comparison of quartz and Teflon filters for simultaneous collection of size- 
separated ultrafine aerosol particles and gas-phase zero samples. Analytical and Bioanalytical Chemistry 400, 3527-3535.

Pope III, C.A., Dockery, D.W., 2006. Health effects of fine particulate air pollution: Lines that connect. Journal of Air \& Waste Management Association 56, 707-742.

Reche, C., Querol, X., Alastuey, A., Viana, M., Pey, J., Moreno, T., Rodríguez, S., Y. González, Y., Fernández-Camacho, R., de la Rosa, J., Dall'Osto, M., Prévôt, A.S.H., Hueglin, C., Harrison, R.M., Quincey, P., 2011. New considerations for PM, Black Carbon and particle number concentration for air quality monitoring across different European cities. Atmospheric Chemistry and Physics 11, 6207-6227.

Reddington, C. L., Carslaw, K.S., Spracklen, D.V., Frontoso, M.G., Collins, L., Merikanto, J., Minikin, A., Hamburger, T., Coe, H., Kulmala, M., et al., 2011. Primary versus secondary contributions to particle number concentrations in the European boundary layer. Atmospheric Chemistry and Physics 11, 12007-120036.

Reid, J.S., Eck, T.F., Christopher, S.A., Koppmann, R., Dubovik, O., Eleuterio, D.P., Holben, B.N., Reid, E.A., Zhang, J., 2005. A review of biomass burning emissions part III: intensive optical properties of biomass burning particles. Atmospheric Chemistry and Physics 5, 827-849.

Ristovski, Z.D., Suni, T., Kulmala, M., Boy, M., Meyer, N.K., Duplissy, J., Turnipseed, A., Morawska, L., Baltensperger, U., 2010. The role of sulphates and organic vapours in growth of newly formed particles in a eucalypt forest. 10, 2919-2926.

Robinson, A.L., Donahue, N.M., Shrivastava, M.K., Weitkamp, E.A., Sage, A.M., Grieshop, A.P., Lane, T.E., Pierce, J.R., Pandis, S.N. , 2007. Rethinking organic aerosols: Semivolatile emissions and photochemical aging. Science 315, 1259-1262.

Rodríguez, S., Cuevas, E., González, Y., Ramos, R., Romero, P.M., Pérez, N., Querol, X., Alastuey, A., 2008. Influence of sea breeze circulation and road traffic emissions on the relationship between particle number, black carbon, PM1, PM2.5 and PM2.5-10 concentrations in a coastal city. Atmospheric Environment 42, 6523-6534.

Roes, L., Patel, M.K., Worrell, E., Ludwig, C., 2012. Preliminary evaluation of risks related to waste incineration of polymer nanocomposites. Science of the Total Environment, In press.

Rogers, F., Arnott, P., Zielinska, B., Sagebiel, J., Kelly, K.E., Wagner, D., Lighty, J.S., Sarofim, A.F., 2005. Real-time measurements of jet aircraft engine exhaust. Journal of Air \& Waste Management Association 55, 583-593.

Ruiz-Jimenez, J., Parshintsev, J., Laitinen, T., Hartonen, K., Riekkola, M.-L., Petaja, T., Virkkula, A., Kulmala, M., 2011. A complete methodology for the reliable collection, sample preparation, separation and determination of organic compounds in ultrafine 30 $\mathrm{nm}, 40 \mathrm{~nm}$ and $50 \mathrm{~nm}$ atmospheric aerosol particles. Analytical Methods 3, 2501-2509.

Sakurai, H., Fink, M.A., McMurry, P.H., Mauldin, L., Moore, K.F., Smith, J.N., Eisele, F.L., 2005. Hygroscopy and volatility of 4-10 nm particles during summertime atmospheric nucleation events in urban Atlanta. Journal of Geophysical Research 110, D22S04, doi: 10.1029/2005JD005918.

Sakurai, H., Tobias, K., Park, D., Zarling, K.S., Docherty, D., Kittelson, D.B., McMurry, P.H., Zeimann, P.J., 2003. On-line measurements of diesel nanoparticle composition and volatility. Atmospheric Environment 37, 1199-1210.

Sanders, P.G., Xu, N., Dalka, T.M., Maricq, M.M., 2003. Airborne brake wear debris: size distributions, composition, and a comparison of dynamometer and vehicle tests. Environmental Science \& Technology 37, 4060-4069.

Saxe, H., Larsen, T., 2004. Air pollution from ships in three Danish ports. Atmospheric Environment 38, 4057-4067.

Schäfer, K., Jahn, C., Sturm, P., Lechner, B., Bacher, M., 2003. Aircraft emission measurements by remote sensing methodologies at airports. Atmospheric Environment $37,5261-5271$. 
Schauer, J.J., Hildermann, L.M., Mazurek, M.A., Cass, G.R., Simoneit, B.R.T., 1996a. Source apportionment of airborne particulate matter using organic compounds as tracers. Atmospheric Environment 30, 3837-3855.

Schauer, J.J., Kleeman, M.J., Cass, G.R., Simoneit, B.R.T., 2001. Measurement of emissions from air pollution sources. 3. C1-C29 organic compounds from fireplace combustion of wood. Environmental Science \& Technology 35, 1716-1728.

Schauer, J.J., Rogge, W.F., Hildemann, L.M., Mazurek, M.A., Cass, G.R., 1996b. Source apportionment of airborne particulate matter using organic compounds as tracers. Atmospheric Environment 30, 3837-3855.

Schneider, J., Hock, N., Weimer, S., Borrmann, S., 2005. Nucleation particles in diesel exhaust: Composition inferred from in situ mass spectrometric analysis. Environmental Science \& Technology 39, 6153-6161.

Schröder, F., Petzold, A., Kärcher, B., 1998. Ultrafine particulate jet aircraft emissions depending on fuel sulfur content and contrail processing. Journal of Aerosol Science 29, S561-S562.

See, S.W., Balasubramanian, R., 2006. Risk assessment of exposure to indoor aerosols associated with Chinese cooking. Environmental Research 102, 197-204.

Senior, C.L., Bool, L.E., Srinivasachar, S., Pease, B.R., Porle, K., 2000. Pilot scale-study of trace element vaporization and condensation during combustion of a pulverized subbituminous coal. Fuel Processing Technology 63, 149-165.

Shi, P.J., Harrison, R.M., 1999. Investigation of ultrafine particle formation during diesel exhaust dilution. Envrionmental Science \& Technology 33, 3730-3736.

Silva, L.F., da Boit, K.M., 2011. Nanominerals and nanoparticles in feed coal and bottom ash: implications for human health effects. Environmental Monitoring and Assessment 174, 187-197.

Sinha, P., Hobbs, P.V., Yokelson, R.J., Christian, T.J., Kirchstetter, T.W., Bruintjes, R., 2003. Emissions of trace gases and particles from two ships in the southern Atlantic Ocean. Atmospheric Environment 37, 2139-2148.

Sipila, M., Berndt, T., Petaja, T., Brus, D., Vanhanen, J., Stratmann, F., Patokoski, J., Mauldin III, R.L., Hyvärinen, A.P., Lihavainen, H., Kulmala, M., 2010. The role of sulfuric acid in atmospheric nucleation. Science 327, 1243-1246.

Smith, J.N., Moore, K.F., Eisele, F.L., Voisin, D., Ghimire, A.K., Sakuri, H., McMurry, P.H., 2005. Chemical composition of atmospheric nanoparticles during nucleation events in Atlanta. Journal of Geophysical Research 110, D22S03, doi:10.1029/2005JD005912.

Sodeman, D.A., Toner, S.M., Prather, K.A., 2005. Determination of single particle mass spectral signatures from light-duty vehicle emissions. Environmental Science \& Technology 39, 4569-4580.

Stölzel, M., Breitner, S., Cyrys, J., Pitz, M., Wölke, G., Kreyling, W., Heinrich, J., Wichmann, H.E., Peters, A., 2007. Daily mortality and particulate matter in different size classes in Erfurt, Germany. Journal of Exposure Science and Environmental Epidemiology 17, 458-467.

Straif, K., Baan, R., Grosse, Y., Secretan, B., El Ghissassi, F., Cogliano, V., 2006. Carcinogenicity of household solid fuel combustion and of high-temperature frying. Lancet Oncol 7, 977-978.

Su, V., Sipin, M.F., Furutani, H., Prather, K.A., 2004. Development and characterization of an Aerosol Time-of-Flight Mass Spectrometer with increased detection efficiency. Analytical Chemistry 76, 712-719.

Suess, D.T., Prather, K.A., 1999. Mass spectrometry of aerosols. Chemical Reviews 99, 30073035.

Tervahattu, H., Kupiainen, K.J., Räisänen, M., Mäkelä, T., 2006. Generation of urban road dust from anti-skid and asphalt concrete aggregates. Journal of Hazardous materials 132, $30-46$.

Thorpe, A., Harrison, R.M., 2008. Sources and properties of non-exhaust particulate matter form road traffic: A review. Science of the Total Environment 400, 270-282. 
Tian, H., Cheng, K., Wang, Y., Zhao, D., Lu, L., Jia, W., Hao, J., 2012. Temporal and spatial variation characteristics of atmospheric emissions of $\mathrm{Cd}, \mathrm{Cr}$, and $\mathrm{Pb}$ from coal in China. Atmospheric Environment 50, 157-163.

Tissari, J., Lyyränen, J., Hytönen, K., Sippula, O., Tapper, U., Frey, A., Saarnio, K., Pennanen, A.S., Hillamo, R., Salonen, R.O., Hirvonen, M.R., Jokiniemi, J., 2008. Fine particle and gaseous emissions from normal and smouldering wood combustion in a conventional masonry heater. Atmospheric Environment 42, 7862-7873.

Tobias, H.J., Beving, D., Ziemann, P.J., 2001. Chemical analysis of diesel engine nanoparticles using a nano-DMA/thermal desorption particle beam mass spectrometer. Environmental Science \& Technology 35, 2233-2243.

Tunved, P., Hansson, H.-C., Kerminen, V.-M., Ström, J., Dal Maso, M., Lihavainen, H., Viisanen, Y., Aalto, P.P., Komppula, M., Kulmala, M., 2006. High natural aerosol loading over boreal forests. Science 312, 261-263.

Unal, A., Hu, Y., Chang, M.E., Talat Odman, M., Russell, A.G., 2005. Airport related emissions and impacts on air quality: Application to the Atlanta International Airport. Atmospheric Environment 39, 5787-5798.

Urciuolo, M., Barone, A., D'Alessio, A., Chirone, R., 2008. Fine and ultrafine particles generated during fluidized bed combustion of different solid fuels. Environmental Engineering Science 25, 1399-1406.

USDHHS, 2006. US Department of Health and Human Services. The health consequences of involuntary expsoure to tobacco smoke: a report of the Surgeon General. DHHS, Washington, DC http://www.ncbi.nlm.nih.gov/books/NBK44324/ Accessed online 15.05.2012.

Valente, P., Forastiere, F., Bacosi, A., Cattani, G., Di Carlo, S., Ferri, M., Figà-Talamanca, I., Marconi, A., Paoletti, L., Perucci, C., Zuccaro, P., 2007. Exposure to fine and ultrafine particles from secondhand smoke in public places before and after the smoking ban, Italy 2005. Tobacco Control 16, 312-317.

Vehkamaki, H., Dal Maso, M., Hussein, T., Flanagan, R., Hyvarinen, A., Lauros, J., Merikanto, P., Monkkonen, M., Pihlatie, K., Salminen, K., Sogacheva, L., Thum, T., Ruuskanen, T.M., Keronen, P., Aalto, P.P., Hari, P., Lehtinen, K.E.J., Rannik, U., Kulmala, M., 2004. Atmospheric particle formation events at Varrio measurement station in Finnish Lapland: 1998-2002. Atmospheric Chemistry and Physics 4, 2015-2023.

Viana, M., Kuhlbusch, T.A.J., Querol, X., Alastuey, A., Harrison, R.M., Hopke, P.K., Winiwarter, W., Vallius, M., Szidat, S., Prévôt, A.S.H., Hueglin, C., Bloemen, H., Wåhlin, P., Vecchi, R., Miranda, A.I., Kasper-Giebl, A., Maenhaut, W., Hitzenberger, R., 2008. Source apportionment of particulate matter in Europe: A review of methods and results. Journal of Aerosol Science 39, 827-849.

Wåhlin, P., 2009. Measured reduction of kerbside ultrafine particle number concentrations in Copenhagen. Atmospheric Environment 43, 3645-3647.

Wåhlin, P., Berkowicz, R., Palmgren, F., 2006. Characterisation of traffic-generated particulate matter in Copenhagen. Atmospheric Environment 40, 2151-2159.

Wåhlin, P., Olesen, H.R., Bossi, R., Stubkjær, J., 2010. Air pollution from residential wood combustion in a Danish village. Measuring campaign and analysis of results. National Environmental Research Institute, Aarhus University Denmark NERI Technical Report No. 777, pp. 49, Download from: http://www.dmu.dk/Pub/FR777.pdf.

Wåhlin, P., Palmgren, F., Van Dingenen, R., 2001. Experimental studies of ultrafine particles in streets and the relatioship of traffic. Atmospheric Environment 35, S63-S69.

Wallace, L., Ott, W., 2011. Personal exposure to ultrafine particles. Journal of Exposure Science and Environmental Epidemiology 21, 20-30.

Wallace, L.A., Emmerich, S.J., Howard-Reed, C., 2004. Source strengths of ultrafine and fine particles due to cooking with a gas stove. Environmental Science \& Technology 38, 2304-2311.

Wan, M.-P., Wu, C.-L., Sze To, G.-N., Chan, T.-C., Chao, C.Y.H., 2011. Ultrafine particles, and PM2.5 generated from cooking in homes. Atmospheric Environment 45, 6141-6148. 
Wang, H.L., Hao, Z.P., Zhuang, Y.H., Wang, W., Liu, X.Y., 2008. Characterization of inorganic components of size-segregated particles in the flue gas of a coal-fired power plant. Energy and Fuels 22, 1636-1640.

Wardoyo, A.Y.P., 2007. Biomass burning: particle emissions, characteristics, and airborne measurements. PhD Thesis. Quensland University of Technology, Brisbane Australia, pp. 218.

Wardoyo, A.Y.P., Morawska, L., Ristovski, Z.D., Marsh, J., 2006. Quantification of Particle Number and Mass Emission Factors from Combustion of Queensland Trees. Environmental Science \& Technology 40, 5696-5703.

Weber, R.J., Moore, K., Kapustin, V., Clarke, A., Mauldin, R.L., Kosciuch, E., Cantrell, C., Eisele, F., Anderson, B., Thornhill, L., 2001. Nucleation in the equatorial pacific during PEM-tropics B: Enhanced boundary layer $\mathrm{H} 2 \mathrm{SO} 4$ but no particle production: NASA global tropospheric experiment Pacific Exploratory Mission in the tropics phase B, Part 1: Measurement and analyses (PEM-Tropics B). Journal of Geophysical Research 106, 32767-32776.

Westerling, A.L., Hidalgo, H.G., Cayan, D.R., Swetnam, T.W., 2007. Warming and earlier spring increase western U.S. forest wildfire activity. Science 313, 940-942.

WHO, 2002. World health report: Reducing risks, promoting healthy life. Geneva: World Health Organization.

Wu, C.L., Chao, Y.H.C., Sze-ToM, G.N., Wan, P., Chan, T.C., 2011. Ultrafine particle emissions from cigarette smouldering, incense burning, vacuum cleaner motor operation and cooking. Indoor and Built Environment in press. doi: 10.1177/1420326X11421356.

Wu, Z., Hu, M., Lin, P., Liu, S., Wehner, B., Wiedensohler, A., 2008. Particle number size distribution in the urban atmosphere of Beijing, China. Atmospheric Environment 42, 7967-7980.

Yi, H., Hao, J., Duan, L., Li, X., Guo, X., 2006. Characteristics of inhalable particulate matter concentration and size distribution from power plants in China. Journal of Air \& Waste Management Association 56, 1243-1251.

Yokelson, R.J., Karl, T., Artaxo, P., Blake, D.R., Christian, T.J., Griffith, D.W.T., Guenther, A., Hae, W.M., 2007. The tropical forest and fire emisions experiment: overview and airborne fire emission factor measurements. Atmospheric Chemistry and Physics 7, 5175-5196.

Yoo, J.I., Seo, Y.C., Shinagawa, T., 2005. Particle size distribution and heavy metal partitioning in emission gas from different coal-fired power plants. Environmental Engineering Science 22, 272-279.

Zhang, H., Wang, S., Hao, J., Wan, L., Jiang, J., Zhang, M., Mestl, H.E.S., Alnes, L.W.H., Aunan, K., Mellouki, A.W., 2012. Chemical and size characterization of particles emitted from the burning of coal and wood in rural households in Guizhou, China. Atmospheric Environment in press, doi: 0.1016/j.atmosenv.2012.1001.1042.

Zhang, Q., Gangupomu, R.H., Ramirez, D., Zhu, Y., 2010. Measurement of ultrafine particles and other air pollutants emitted by cooking activities. International Journal of Environmental Research and Public Health 7, 7(4): 1744-1759.

Zhang, Q., Stanier, C.O., Canagaratna, M.R., Jayne, J.T., Worsnop, D.R., Pandis, S.N., Jimenez, J.L., 2004. Insights into the chemistry of new particle formation and growth events in Pittsburgh based on aerosol mass spectrometry. Environmental Science \& Technology 38, 4797-4809.

Zhao, Y., Wang, S., Nielsen, C.P., Li, X., Hao, J., 2010. Establishment of a database of emission factors for atmospheric pollutants from Chinese coal-fired power plants. Atmospheric Environment 44, 1515-1523.

Zhu, N., Ma, Z., Wang, S., 2009. Dynamic characteristics and energy performance of buildings using phase change materials: A review. Energy Conversion and Management 50, 3169-3181. 
Citation details:

Kumar, P., Pirjola, L., Ketzel, M., Harrison, R.M. 2013. Nanoparticle emissions from 11 non-vehicle exhaust sources - a review. Atmospheric Environment 67, 252-277. http://dx.doi.org/10.1016/j.atmosenv.2012.11.011

Zhu, Y., Fanning, E., Yu, R.C., Zhang, Q., Froines, J.R., 2011. Aircraft emissions and local air quality impacts from takeoff activities at a large International Airport. Atmospheric Environment 45, 6526-6533.

Zhuang, Y., Biswas, P., 2001. Submicrometer particle formation and control in a bench-ccale pulverized coal combustor. Energy and Fuels 15, 510-516. 
Table 1. Sample summary of nanoparticle emissions from various NES to atmospheric environment. The abbreviations $P, L$ and A refer to point (fixed point emissions), line (emissions in a continuous row) and area (spread over an area) sources, respectively.

\begin{tabular}{|c|c|c|c|c|c|c|}
\hline Sources & Type & $\begin{array}{l}\text { PNC }\left(\mathrm{cm}^{-3}\right) / \text { PNEF }(\# \\
\left.\mathrm{km}^{-1} \text { or \# } \mathrm{kg}^{-1}\right) \pm \\
\text { STDEV }\end{array}$ & Instrument & $\begin{array}{l}\text { Size } \\
\text { range } \\
(\mathrm{nm})\end{array}$ & Remarks & $\begin{array}{l}\text { Authors } \\
\text { (year) }\end{array}$ \\
\hline \multirow[t]{4}{*}{ Road-tyre interaction } & $\mathrm{L}$ & $\begin{array}{l}4-10 \times 10^{11} \mathrm{~km}^{-1} \text { for } \\
\text { non-studded tyre } \\
6-30 \times 10^{11} \mathrm{~km}^{-1} \\
\text { for studded tyre }\end{array}$ & SMPS & $15-700$ & $\begin{array}{l}\text { vehicle speed } \\
50-70 \mathrm{~km} \mathrm{~h}^{-1}\end{array}$ & $\begin{array}{l}\text { Dahl et al. } \\
\text { (2006) }\end{array}$ \\
\hline & $\mathrm{L}$ & $\begin{array}{l}0.14-0.17 \times 10^{4} \mathrm{~cm}^{-3} \\
0.72-0.82 \times 10^{4} \mathrm{~cm}^{-3} \\
1.81-2.65 \times 10^{4} \mathrm{~cm}^{-3}\end{array}$ & $\begin{array}{l}\text { SMPS } \\
\text { SMPS } \\
\text { SMPS }\end{array}$ & $\begin{array}{l}15-700 \\
15-700 \\
15-700\end{array}$ & $\begin{array}{l}30 \mathrm{~km} \mathrm{~h}^{-1} \\
50 \mathrm{~km} \mathrm{~h}^{-1} \\
60 \mathrm{~km} \mathrm{~h}^{-1}\end{array}$ & $\begin{array}{l}\text { Gustafsson } \\
\text { et al. } \\
\text { (2008) }\end{array}$ \\
\hline & $\mathrm{L}$ & $1 \times 10^{11} \mathrm{~km}^{-1}$ & EEPS & $6-562$ & summer tyre & $\begin{array}{l}\text { Mathissen } \\
\text { et al. } \\
\text { (2011) }\end{array}$ \\
\hline & $\mathrm{L}$ & $1 \times 10^{7} \mathrm{~cm}^{-3}$ & EEPS & $6-562$ & $\begin{array}{l}\text { full stop } \\
\text { braking }\end{array}$ & $\begin{array}{l}\text { Mathissen } \\
\text { et al. } \\
\text { (2011) }\end{array}$ \\
\hline Construction and demolition & A & $\begin{array}{l}{ }^{\mathrm{a}} 1.91 \times 10^{5} \mathrm{~cm}^{-3} \\
{ }^{\mathrm{a}} 2.27 \times 10^{5} \mathrm{~cm}^{-3} \\
{ }^{\mathrm{a}} 1.76 \times 10^{4} \mathrm{~cm}^{-3} \\
{ }^{\mathrm{a}} 0.77 \times 10^{4} \mathrm{~cm}^{-3}\end{array}$ & $\begin{array}{l}\text { DMS50 } \\
\text { DMS50 } \\
\text { DMS50 } \\
\text { DMS50 } \\
\end{array}$ & $\begin{array}{l}5-560 \\
5-560 \\
5-560 \\
5-560 \\
\end{array}$ & $\begin{array}{l}\text { Demolition } \\
\text { Dry recycling } \\
\text { Wet recycling } \\
\text { crushing }\end{array}$ & $\begin{array}{l}\text { Kumar et } \\
\text { al. }(2012 \mathrm{c})\end{array}$ \\
\hline \multirow[t]{7}{*}{ Ship emissions } & $\mathrm{L}$ & $\begin{array}{l}(1.26 \pm 0.51) \times 10^{15} \\
\mathrm{~cm}^{-3} \text { as raw exhaust }\end{array}$ & CPC & $>10$ & $\begin{array}{l}\text { Aircraft based } \\
\text { measurement } \\
2004\end{array}$ & $\begin{array}{l}\text { Petzold et } \\
\text { al. (2008) }\end{array}$ \\
\hline & $\mathrm{L}$ & $7.8 \times 10^{5} \mathrm{~cm}^{-3}$ & DMA & $10-800$ & $\begin{array}{l}\text { Aircraft based } \\
\text { measurement } \\
2007\end{array}$ & $\begin{array}{l}\text { Murphy et } \\
\text { al. (2009) }\end{array}$ \\
\hline & $\mathrm{L}$ & $2.1 \times 10^{5} \mathrm{~cm}^{-3}$ & $\begin{array}{l}\text { SMPS3081 } \\
\text { TSI }\end{array}$ & $20-600$ & Harbour & $\begin{array}{l}\text { Healy et al. } \\
\text { (2009) }\end{array}$ \\
\hline & $\mathrm{L}$ & $\begin{array}{l}(6.2 \pm 0.6) \times 10^{16} \mathrm{~kg}^{-1} \\
\text { fuel }\end{array}$ & $\begin{array}{l}\text { CNC3025 } \\
\text { TSI }\end{array}$ & $3-3000$ & $\begin{array}{l}\text { Aircraft based } \\
\text { measurement } \\
2000\end{array}$ & $\begin{array}{l}\text { Sinha et al. } \\
(2003)\end{array}$ \\
\hline & $\mathrm{L}$ & $\begin{array}{l}(1.36 \pm 0.24) \times 10^{16} \\
\mathrm{~kg}^{-1} \text { fuel }\end{array}$ & $\mathrm{CPC}$ & $>10$ & $\begin{array}{l}\text { Aircraft based } \\
\text { measurement } \\
2004\end{array}$ & $\begin{array}{l}\text { Petzold et } \\
\text { al. (2008) }\end{array}$ \\
\hline & $\mathrm{L}$ & $\begin{array}{l}(1.3 \pm 0.2) \times 10^{16} \\
\mathrm{~kg}^{-1} \text { fuel }\end{array}$ & $\begin{array}{l}\text { CPC3025 } \\
\text { TSI }\end{array}$ & $>3$ & $\begin{array}{l}\text { Aircraft based } \\
\text { measurement } \\
2007\end{array}$ & $\begin{array}{l}\text { Murphy et } \\
\text { al. (2009) }\end{array}$ \\
\hline & $\mathrm{L}$ & $\begin{array}{l}(2.46 \pm 0.11) \times 10^{16} \\
\mathrm{~kg}^{-1} \text { fuel } \\
(3.19 \pm 0.41) \times 10^{16} \\
\mathrm{~kg}^{-1} \text { fuel } \\
\end{array}$ & $\begin{array}{l}\text { EEPS3090 } \\
\text { TSI } \\
\text { CPC3775 } \\
\text { TSI } \\
\end{array}$ & $\begin{array}{l}5.6- \\
560 \\
>3 \\
\end{array}$ & $\begin{array}{l}\text { Harbour } \\
\text { Harbour }\end{array}$ & $\begin{array}{l}\text { Jonsson et } \\
\text { al. (2011) }\end{array}$ \\
\hline \multirow[t]{7}{*}{ Aircraft emissions } & $\mathrm{L}$ & $\begin{array}{l}4.2-54 \times 10^{15} \\
\mathrm{~kg}^{-1} \text { fuel }\end{array}$ & SMPS & $4-710$ & $\begin{array}{l}\text { Various } \\
\text { modes in } \\
\text { landing/take- } \\
\text { off cycle } \\
\end{array}$ & $\begin{array}{l}\text { Mazaheri } \\
\text { et al. } \\
\text { (2009) }\end{array}$ \\
\hline & $\mathrm{L}$ & $\begin{array}{l}1.98 \times 10^{24} \mathrm{yr}^{-1} \\
\text { (Airport annual total } \\
\text { number emissions) }\end{array}$ & SMPS & $4-710$ & $\begin{array}{l}\text { Brisbane } \\
\text { airport total } \\
\text { emissions }\end{array}$ & $\begin{array}{l}\text { Mazaheri } \\
\text { et al. } \\
\text { (2011) }\end{array}$ \\
\hline & $\mathrm{L}$ & $3-50 \times 10^{15} \mathrm{~kg}^{-1}$ fuel & $\begin{array}{l}\text { CPC 3022a } \\
\text { TSI }\end{array}$ & $>7$ & $\begin{array}{l}\text { Idle and take- } \\
\text { off plumes }\end{array}$ & $\begin{array}{l}\text { Herndon et } \\
\text { al. }(2008)\end{array}$ \\
\hline & $\mathrm{L}$ & $10^{15}-10^{17} \mathrm{~kg}^{-1}$ fuel & $\begin{array}{l}\text { EEPS3090 } \\
\text { TSI }\end{array}$ & $\begin{array}{l}5.6- \\
560\end{array}$ & $\begin{array}{l}\text { Idle and take- } \\
\text { off plumes }\end{array}$ & $\begin{array}{l}\text { Kinsey et } \\
\text { al. (2010) }\end{array}$ \\
\hline & $\mathrm{L}$ & $3.4 \times 10^{16} \mathrm{~kg}^{-1}$ fuel & $\begin{array}{l}\text { SMPS } \\
\text { /CPC } 3785 \\
\text { TSI } \\
\end{array}$ & $7-320$ & $\begin{array}{l}\text { Take off } \\
\text { plumes }\end{array}$ & $\begin{array}{l}\text { Zhu et al. } \\
\text { (2011) }\end{array}$ \\
\hline & A & $\begin{array}{l}4 \times 10^{4} \mathrm{~cm}^{-3} \text { (average) } \\
3-6 \times 10^{5} \mathrm{~cm}^{-3} \text { (peaks) }\end{array}$ & DMPS & $6-700$ & $\begin{array}{l}\text { Handling } \\
\text { Area }\end{array}$ & $\begin{array}{l}\text { Ellermann } \\
\text { et al. } \\
(2011) \\
\end{array}$ \\
\hline & A & $\begin{array}{l}2.6 \times 10^{4} \mathrm{~cm}^{-3} \text { (runway) } \\
1.7 \times 10^{4} \mathrm{~cm}^{-3} \text { (hangar) } \\
\text { (both average } 8 \mathrm{~h} \\
\text { working day) }\end{array}$ & $\begin{array}{l}\text { FMPS } 3091 \\
\text { CPC } 3775\end{array}$ & $\begin{array}{l}5-560 \\
>4\end{array}$ & $\begin{array}{l}\text { Near runway } \\
\text { and hangar at } \\
\text { an aviation } \\
\text { base }\end{array}$ & $\begin{array}{l}\text { Buonanno } \\
\text { et al. } \\
\text { (2012b) }\end{array}$ \\
\hline Domestic biomass burning & $\mathrm{P}$ & $\begin{array}{l}\mathrm{b}^{\mathrm{b}} 34 \times 10^{15} \times(1-\mathrm{MCE}) \\
\mathrm{kg}^{-1}(\mathrm{PNEF})\end{array}$ & $\begin{array}{l}\text { Fit based } \\
\text { on }\end{array}$ & $\begin{array}{l}\text { Variou } \\
\mathrm{s}\end{array}$ & $\begin{array}{l}\text { Vegetation } \\
\text { fires }\end{array}$ & $\begin{array}{l}\text { Janhäll et } \\
\text { al. (2010) }\end{array}$ \\
\hline
\end{tabular}


Kumar, P., Pirjola, L., Ketzel, M., Harrison, R.M. 2013. Nanoparticle emissions from 11 non-vehicle exhaust sources - a review. Atmospheric Environment 67, 252-277. http://dx.doi.org/10.1016/j.atmosenv.2012.11.011

\begin{tabular}{|c|c|c|c|c|c|c|}
\hline & & $\begin{array}{l}(34 \pm 16) \mathrm{cm}^{-3} \mathrm{ppb}^{-1} \\
\text { Ratio of } \mathrm{PN} \text { emissions } \\
\text { relative to } \mathrm{CO} \\
\text { emissions }\end{array}$ & $\begin{array}{l}\begin{array}{l}\text { literature } \\
\text { data }\end{array} \\
\text { Fit based } \\
\text { on } \\
\text { literature } \\
\text { data }\end{array}$ & $\begin{array}{l}\text { studies } \\
\text { and } \\
\text { instrum } \\
\text { ents } \\
\text { Typical } \\
1 \text { size } \\
\text { range } \\
>20\end{array}$ & $\begin{array}{l}\text { (MCE }= \\
\text { modified } \\
\text { combustion } \\
\text { efficiency) }\end{array}$ & \\
\hline & $\mathrm{P}$ & $2 \times 10^{3} \mathrm{~cm}^{-3}$ & DMPS & $6-700$ & $\begin{array}{l}\text { Increase in } \\
\text { outdoor PNC } \\
\text { due to } \\
\text { residential } \\
\text { wood } \\
\text { combustion } \\
\end{array}$ & $\begin{array}{l}\text { Glasius et } \\
\text { al. (2008); } \\
\text { Wåhlin et } \\
\text { al. (2010) }\end{array}$ \\
\hline & $\mathrm{P}$ & $\begin{array}{l}3.3-5.7 \times 10^{15} \mathrm{~kg}^{-1} \\
\text { (wood) } \\
0.5-6.9 \times 10^{15} \mathrm{~kg}^{-1} \\
\text { (leaves) } \\
2.8-45 \times 10^{13} \mathrm{~kg}^{-1} \\
\text { (wood) } \\
0.5-9.3 \times 10^{13} \mathrm{~kg}^{-1} \\
\text { (leaves) }\end{array}$ & DMPS & $10-600$ & $\begin{array}{l}\text { PNEF; Fast } \\
\text { burning } \\
\text { PNEF; Fast } \\
\text { burning } \\
\text { PNEF; Slow } \\
\text { burning } \\
\text { PNEF; Slow } \\
\text { burning }\end{array}$ & $\begin{array}{l}\text { Wardoyo } \\
\text { et al. } \\
(2006)\end{array}$ \\
\hline & $\mathrm{P}$ & $\begin{array}{l}1.5-8 \times 10^{7} \mathrm{~cm}^{-3} \\
(\text { Median) } \\
0.13-9.7 \times 10^{14} \mathrm{~kg}^{-1} \\
(\mathrm{PNEF})\end{array}$ & DMPS & $3-920$ & Birch wood & $\begin{array}{l}\text { Hedberg et } \\
\text { al. (2002) }\end{array}$ \\
\hline & $\mathrm{P}$ & $1.8-3.7 \times 10^{5} \mathrm{~cm}^{-3}$ & $\begin{array}{l}\text { WCPC + } \\
\text { WPC }\end{array}$ & $\begin{array}{l}10- \\
10,000\end{array}$ & $\begin{array}{l}\text { Range for } \\
\text { locally grown } \\
\text { wood burning } \\
\text { in different } \\
\text { stages of } \\
\text { combustion }\end{array}$ & $\begin{array}{l}\text { Zhang et } \\
\text { al. (2012) }\end{array}$ \\
\hline \multirow[t]{4}{*}{ Forest fires } & $\mathrm{A}$ & $1.5 \times 10^{15} \mathrm{~kg}^{-1}$ fuel & $\mathrm{CPC}$ & $8-300$ & $\begin{array}{l}\text { Aircraft } \\
\text { measurement } \\
\text { in the tropical } \\
\text { forest plume } \\
2002\end{array}$ & $\begin{array}{l}\text { Guyon et } \\
\text { al.,(2005) }\end{array}$ \\
\hline & A & $\begin{array}{l}(30 \pm 17) \times 10^{15} \mathrm{~kg}^{-1} \\
\text { fuel }\end{array}$ & $\mathrm{CPC}$ & $3-3000$ & $\begin{array}{l}\text { Aircraft } \\
\text { measurement } \\
\text { in the } \\
\text { savannah } \\
\text { burning } \\
\text { plume } 2000\end{array}$ & $\begin{array}{l}\text { Sinha et al. } \\
(2004)\end{array}$ \\
\hline & $\mathrm{A}$ & $3.4 \times 10^{15} \mathrm{~kg}^{-1}$ fuel & $\begin{array}{ll}- \\
-\end{array}$ & $\begin{array}{l}\text { Conde } \\
\text { nsation } \\
\text { nuclei } \\
\end{array}$ & $\begin{array}{l}\text { Laboratory } \\
\text { studies }\end{array}$ & $\begin{array}{l}\text { Andreae } \\
\text { and Merlet } \\
(2001) \\
\end{array}$ \\
\hline & $\mathrm{A}$ & $\begin{array}{l}(1.2-3.4) \times 10^{15} \\
\mathrm{~kg}^{-1} \text { fuel }\end{array}$ & $\begin{array}{l}\text { PCASP for } \\
\text { grass; } \\
\text { CPC for } \\
\text { forest }\end{array}$ & $\begin{array}{l}>100 \\
\mathrm{~nm} ; \\
8-300 \\
\mathrm{~nm}\end{array}$ & $\begin{array}{l}\text { Forest, } \\
\text { savanna, } \\
\text { grass }\end{array}$ & $\begin{array}{l}\text { Janhäll et } \\
\text { al. (2010) }\end{array}$ \\
\hline \multirow[t]{3}{*}{ MSW incineration } & $\mathrm{P}$ & ${ }^{\mathrm{c}} \sim 10^{3} \mathrm{~cm}^{-3}$ & $\begin{array}{l}\text { APS+SMP } \\
\mathrm{S}\end{array}$ & $\begin{array}{l}17- \\
30000\end{array}$ & -- & $\begin{array}{l}\text { Maghun et } \\
\text { al. (2003) }\end{array}$ \\
\hline & $\mathrm{P}$ & ${ }^{\mathrm{d}} 1-2 \times 10^{5} \mathrm{~cm}^{-3}$ & ELPI & $\begin{array}{l}30- \\
10000\end{array}$ & May 2007 & $\begin{array}{l}\text { Buonanno } \\
\text { et al. } \\
(2009 a)\end{array}$ \\
\hline & $\mathrm{P}$ & ${ }^{\mathrm{e}} 0.35 \pm 1 \times 10^{3} \mathrm{~cm}^{-3}$ & $\begin{array}{l}\mathrm{CPC}+\mathrm{SMP} \\
\mathrm{S}\end{array}$ & $3-800$ & October 2009 & $\begin{array}{l}\text { Buonanno } \\
\text { et al. } \\
(2011)\end{array}$ \\
\hline \multirow[t]{3}{*}{ Power plants } & $\mathrm{P}$ & $\begin{array}{l}\sim 10^{8} \mathrm{~cm}^{-3} \text { (at ESP } \\
\text { inlet) } \\
\sim 10^{5} \mathrm{~cm}^{-3} \text { (at ESP } \\
\text { outlet) }\end{array}$ & $\begin{array}{l}\text { SMPS+EL } \\
\text { PI }\end{array}$ & $\begin{array}{l}17- \\
10000\end{array}$ & $\begin{array}{l}160 \mathrm{~kW} \\
\text { Pilot-scale } \\
\text { coal } \\
\text { combustor }\end{array}$ & $\begin{array}{l}\text { Li et al. } \\
(2009)\end{array}$ \\
\hline & $\mathrm{P}$ & $\begin{array}{l}6 \times 10^{8} \mathrm{~cm}^{-3} \text { (at ESP } \\
\text { outlet) }\end{array}$ & EEPS+APS & $\begin{array}{l}3- \\
10000\end{array}$ & $\begin{array}{l}100 \mathrm{MW} \\
\text { Ignite- } \\
\text { powered } \\
\text { power plants }\end{array}$ & $\begin{array}{l}\text { Wang et al. } \\
(2008)\end{array}$ \\
\hline & $\mathrm{P}$ & $\begin{array}{l}1.7-20.3 \times 10^{6} \mathrm{~cm}^{-3} \text { (at } \\
\text { ESP inlet) } \\
1.7-20.3 \times 10^{6} \mathrm{~cm}^{-3} \text { (at } \\
\text { ESP outlet) } \\
2.4 \times 10^{6} \mathrm{~cm}^{-3} \text { (at } \\
\text { baghouse filter inlet) }\end{array}$ & ELPI & $\begin{array}{l}30- \\
10000\end{array}$ & $\begin{array}{l}\text { Coal-fired } \\
\text { power plants }\end{array}$ & $\begin{array}{l}\text { Yi et al. } \\
(2006)\end{array}$ \\
\hline
\end{tabular}


Kumar, P., Pirjola, L., Ketzel, M., Harrison, R.M. 2013. Nanoparticle emissions from 11 non-vehicle exhaust sources - a review. Atmospheric Environment 67, 252-277. http://dx.doi.org/10.1016/j.atmosenv.2012.11.011

\begin{tabular}{|c|c|c|c|c|c|c|}
\hline & & $\begin{array}{l}6.1 \times 10^{3} \mathrm{~cm}^{-3} \text { (at } \\
\text { baghouse filter outlet) }\end{array}$ & & & & \\
\hline \multirow[t]{6}{*}{ Cigarette smoking } & $\mathrm{L} / \mathrm{P}$ & $1-5.1 \times 10^{12}$ cigarette $^{-1}$ & SMPS & $10-445$ & $\begin{array}{l}\text { Cigarettes } \\
\text { smouldering }\end{array}$ & $\begin{array}{l}\text { Wallace } \\
\text { and Ott } \\
(2011)\end{array}$ \\
\hline & $\mathrm{L} / \mathrm{P}$ & $\begin{array}{l}0.64 \pm 0.19 \times 10^{12} \\
\text { cigarette }^{-1}\end{array}$ & EEPS & $5-560$ & $\begin{array}{l}\text { Cigarette } \\
\text { smouldering }\end{array}$ & $\begin{array}{l}\text { Daher et al. } \\
(2010)\end{array}$ \\
\hline & $\mathrm{L} / \mathrm{P}$ & $3.36 \pm 0.34 \times 10^{11} \mathrm{~min}^{-}$ & SMPS & $17-661$ & $\begin{array}{l}\text { Cigarette } \\
\text { smouldering }\end{array}$ & $\begin{array}{l}\text { Wu et al. } \\
(2011)\end{array}$ \\
\hline & $\mathrm{L} / \mathrm{P}$ & $1.91 \pm 1.92 \times 10^{11} \mathrm{~min}^{-1}$ & SMPS/CPC & $7-808$ & $\begin{array}{l}\text { Cigarette } \\
\text { smouldering }\end{array}$ & $\begin{array}{l}\text { He et al. } \\
(2004)\end{array}$ \\
\hline & $\mathrm{L} / \mathrm{P}$ & $2.13 \times 10^{5} \mathrm{~cm}^{-3}$ & $\mathrm{CPC}$ & $\begin{array}{l}20- \\
1000\end{array}$ & $\begin{array}{l}\text { Cigarette } \\
\text { smouldering } \\
\text { (max PNCs in } \\
\text { chamber) }\end{array}$ & $\begin{array}{l}\text { Afshari et } \\
\text { al. (2005) }\end{array}$ \\
\hline & $\mathrm{L} / \mathrm{P}$ & $3.6 \times 10^{4} \mathrm{~cm}^{-3}$ & SMPS & $14-552$ & $\begin{array}{l}\text { Cigarette } \\
\text { smouldering } \\
\text { (max PNCs in } \\
\text { living room) } \\
\end{array}$ & $\begin{array}{l}\text { Hussein et } \\
\text { al. (2006) }\end{array}$ \\
\hline \multirow[t]{6}{*}{$\begin{array}{l}\text { Cooking (restaurant / } \\
\text { residential) }\end{array}$} & $\mathrm{P}$ & $4.7-148.3 \times 10^{11} \mathrm{~min}^{-1}$ & SMPS & $17-661$ & $\begin{array}{l}\text { Six types of } \\
\text { cooking } \\
\text { activities }\end{array}$ & $\begin{array}{l}\text { Wu et al. } \\
(2011)\end{array}$ \\
\hline & $\mathrm{P}$ & $\begin{array}{l}1.2-1.5 \times 10^{12} \mathrm{~min}^{-1} \\
1.1-2.3 \times 10^{12} \mathrm{~min}^{-1} \\
1.1-2.7 \times 10^{10} \mathrm{~min}^{-1}\end{array}$ & $\begin{array}{l}\text { SMPS+AP } \\
\text { S } \\
\text { SMPS+AP } \\
\text { S } \\
\text { SMPS+AP } \\
\text { S }\end{array}$ & $\begin{array}{l}\text { 6- } \\
20000 \\
6- \\
20000 \\
6- \\
20000\end{array}$ & $\begin{array}{l}\text { Backon } \\
\text { grilling over a } \\
\text { gas stove } \\
\text { Frying of } \\
\text { chips over gas } \\
\text { stove } \\
\text { Frying of } \\
\text { chips over } \\
\text { electric stove }\end{array}$ & $\begin{array}{l}\text { Buonanno } \\
\text { et al. } \\
(2009 \mathrm{~b})\end{array}$ \\
\hline & $\mathrm{P}$ & $0.35-7.3 \times 10^{11} \mathrm{~min}^{-1}$ & SMPS/CPC & $7-808$ & $\begin{array}{l}\text { Nine types of } \\
\text { cooking } \\
\text { activities }\end{array}$ & $\begin{array}{l}\text { He et al. } \\
(2004)\end{array}$ \\
\hline & $\mathrm{P}$ & $0.13-6 \times 10^{5} \mathrm{~cm}^{-3}$ & SMPS & $8-289$ & $\begin{array}{l}\text { Range of } \\
\text { Indian, } \\
\text { Italian, } \\
\text { Chinese and } \\
\text { American } \\
\text { cooking } \\
\end{array}$ & $\begin{array}{l}\text { Zhang et } \\
\text { al. (2010) }\end{array}$ \\
\hline & $\mathrm{P}$ & $1.8 \times 10^{4} \mathrm{~cm}^{-3}$ & SMPS & $14-552$ & $\begin{array}{l}\text { Seven types } \\
\text { of cooking } \\
\text { activities }\end{array}$ & $\begin{array}{l}\text { Hussein et } \\
\text { al. (2006) }\end{array}$ \\
\hline & $\mathrm{P}$ & $7.7 \times 10^{4} \mathrm{~cm}^{-3}$ & ELPI & $\begin{array}{l}8- \\
10000\end{array}$ & Stir cooking & $\begin{array}{l}\text { See and } \\
\text { Balasubra } \\
\text { manian } \\
(2006) \\
\end{array}$ \\
\hline Photochemical nucleation & $\mathrm{A}$ & $\begin{array}{l}\left(0.59 \times \_10^{3} ; 3 \% \text { of }\right. \\
\text { ToN }),\end{array}$ & CPC+DMA & $13-800$ & $\begin{array}{l}\text { 2003-2004; } \\
\text { Urban } \\
\text { background; } \\
\text { Barcelona }\end{array}$ & $\begin{array}{l}\text { Pey et al. } \\
(2009)\end{array}$ \\
\hline
\end{tabular}

Note: DMS $=$ Differential Mobility Spectrometer CPC $=$ Condensation Particle Counter; EEPS $=$ Engine Exhaust Particle Sizer; ELPI $=$ Electrical Low Pressure Impactor; APS = Aerodynamic Particle Sizer; DMA = Differential Mobility Analyser; WCPC = Water-based Condensation Particle Counter; WPS $=$ Wide-range Particle Spectrometer; PCASP $=$ Passive Cavity Aerosol Spectrometer Probe

${ }^{\text {a }}$ These are net PNCs (after subtracting the background) measured close to the source; experiments were simulated in the laboratory on a samples.

${ }^{\mathrm{b}} \mathrm{The}$ modified combustion efficiency is defined as $\mathrm{MCE}=\left(\Delta \mathrm{C}_{\mathrm{CO} 2}\right) /\left(\Delta \mathrm{C}_{\mathrm{CO} 2}+\Delta \mathrm{C}_{\mathrm{CO}}\right)$

${ }^{\mathbf{c}}$ These are measured PNCs in the stack after passing through the treatment system (i.e. wet electrostatic dust precipitator); PNCs before filter were of the order of $\sim 10^{5}-10^{6} \mathrm{~cm}^{-3}$.

${ }^{\mathrm{d}}$ These are measured PNCs in the stack after passing through the treatment system (i.e. selective non-catalytic reduction, electrostatic precipitator, spray absorber system, fabric filter). 
Citation details:

Kumar, P., Pirjola, L., Ketzel, M., Harrison, R.M. 2013. Nanoparticle emissions from 11 non-vehicle exhaust sources - a review. Atmospheric Environment 67, 252-277. http://dx.doi.org/10.1016/j.atmosenv.2012.11.011

${ }^{\mathrm{e}}$ These are measured PNCs in the stack after passing through the treatment system (i.e. fabric filter); PNCs before filter were $2.4 \pm 0.2 \times 10^{7} \mathrm{~cm}^{-3}$. 